UNIVERSIDADE DE SÃO PAULO

FACULDADE DE ECONOMIA, ADMINISTRAÇÃO E CONTABILIDADE DE RIBEIRÃO PRETO

DEPARTAMENTO DE CONTABILIDADE

PROGRAMA DE PÓS-GRADUAÇÃO EM CONTROLADORIA E CONTABILIDADE

POLÍTICAS DE CAIXA NO BRASIL: UM ESTUDO CONSIDERANDO RESTRIÇÕES FINANCEIRAS E GOVERNANÇA CORPORATIVA

Aviner Augusto Silva Manoel

Orientador: Prof. Dr. Marcelo Botelho da Costa Moraes

RIBEIRÃO PRETO 
Prof. Dr. Marco Antônio Zago

Reitor da Universidade de São

Paulo

Prof. Dr. Dante Pinheiro Martinelli

Diretor da Faculdade de Economia, Administração e Contabilidade de Ribeirão Preto

Prof $^{a}$. Dra. Adriana Maria Procópio de

Araujo Chefe do Departamento de

Contabilidade

Prof $^{a}$. Dra. Maísa de Souza Ribeiro

Coordenadora do Programa de Pós-Graduação em Controladoria e Contabilidade 


\section{POLÍTICAS DE CAIXA NO BRASIL: UM ESTUDO CONSIDERANDO RESTRIÇÕES FINANCEIRAS E GOVERNANÇA CORPORATIVA}

Dissertação apresentada ao Programa de Pós-Graduação em Controladoria e Contabilidade da Faculdade de Economia, Administração e Contabilidade de Ribeirão Preto da Universidade de São Paulo como requisito para obtenção do título de Mestre em Ciências. Versão Corrigida. A original encontra-se disponível na FEARP/USP.

Orientador: Prof. Dr. Marcelo

Botelho da Costa Moraes

\section{RIBEIRÃO PRETO}


Autorizo a reprodução e divulgação total ou parcial deste trabalho, por qualquer meio convencional ou eletrônico, para fins de estudo e pesquisa, desde que citada a fonte.

Manoel, Aviner Augusto Silva Manoel

Políticas de caixa no Brasil: um estudo considerando restrições financeiras e governança corporativa. Ribeirão Preto, 2016.

101f. : il.

Dissertação de Mestrado, apresentada à Faculdade de Economia, Administração e Contabilidade de Ribeirão Preto/USP. Área de concentração: Contabilidade financeira e finanças.

Orientador: Moraes, Marcelo Botelho da Costa.

1. Cash Holding. 2. IFRS. 3. Crise Financeira. 


\section{FICHA DE APROVAÇÃO}

Nome: Manoel, Aviner Augusto Silva

Título: Políticas de caixa no Brasil: um estudo considerando restrições financeiras e governança corporativa

Dissertação apresentada ao Programa de Pós-Graduação em Controladoria e Contabilidade da Faculdade de Economia, Administração e Contabilidade de Ribeirão Preto da Universidade de São Paulo como requisito para obtenção do título de Mestre em Ciências.

Aprovado em:

Banca Examinadora

Prof. Dr. Instituição:

Julgamento Assinatura:

Prof. Dr. Instituição:

Julgamento Assinatura:

Prof. Dr. Instituição:

Julgamento Assinatura: 
Que ainda enquanto vós tiverdes forças, que batalhes pelos objetivos divinos e sublimes;

Que as forças que emanam de seu coração nunca se esqueçam do envolver da Luz;

Que aos olhos do Pai você sempre esteja voltado ao bem divino;

Que a vontade e o desejo sejam guiados pela Chama Azul, vinda de Alfa e Ômega;

Que a sabedoria divina lhe demonstre os caminhos a serem percorridos;

Que a busca da vida seja a Alegria e o Triunfo;

Que a tua alma nunca esqueça o que sempre fora: criança, leve e inocente;

Que ainda que te sintas fraco, nunca te esqueças de tua origem;

Que mesmo nos momentos de cansaço, há luz;

Que quando sintas saudades de tudo o que já tenha passado, que a memória viva te tragas as lembranças;

Que antes de qualquer existência no mundo real, as vitórias já estejam planejadas no mundo das ideias;

Que no mundo das ideias, o equilíbrio e a recompensa sejam sempre cultivados;

(MANOEL, A. A. S.)

E que enquanto ainda tiveres esperanças, lembre-se sempre:

"É preciso saber para ousar."

"É preciso ousar para querer."

"É preciso querer para ter o Império."

"E para reinar, é preciso calar." 


\section{Agradecimentos}

Agradeço a meu orientador Prof. Dr. Marcelo Botelho da Costa Moraes que me auxiliou de forma intensa na realização de todo o Mestrado, disponibilizando todo o seu conhecimento para a execução e elaboração de forma plena deste trabalho. Do mesmo modo ao Prof. Dr. David Ferreira Lopes Santos por toda a sua contribuição durante a minha vida acadêmica e pelas contribuições neste trabalho. Também ao Prof. Dr. Vinícius Sobreiro e ao Prof. Dr. Guilherme Kirch por suas contribuições neste estudo.

Em especial também menciono os Professores Doutores: Fabiano Guasti Lima e Amaury José Rezende.

Aos amigos do Mestrado minha eterna gratidão por toda a trajetória e pelos momentos compartilhados: Alexandre, Clarice, Gabriel, Laís, Rafaella, Raíssa, Renan, Rogiene e Thiago.

De forma maneira poderia me esquecer da Sra. Eliana da Silva Manoel (Mãe) e do Sr. Nei Manoel (Pai) por terem me proporcionado o que de melhor tenho na vida: caráter, dignidade, educação, honestidade e respeito. A Otávio Augusto Silva Manoel (en Memoriun) e a Caio Manoel, irmãos, de sangue e alma.

"Que não vai dar? Saí de casa ...!" 


\section{RESUMO}

MANOEL, A. A. S. Políticas de caixa no Brasil: um estudo considerando restrições financeiras e governança corporativa. 2016. 101f. Dissertação (Mestrado) - Faculdade de Economia, Administração e Contabilidade de Ribeirão Preto, Universidade de São Paulo, Ribeirão Preto, 2016.

As organizações, para financiar suas atividades, fazem uso de fontes internas e externas de recursos financeiros. Entretanto, na presença de imperfeições no mercado de capitais, como assimetria de informações, problemas de agência e custos de transação, elas podem optar por uma fonte em detrimento a outra. As imperfeições do mercado aliadas as restrições de financeiras podem afetar o gerenciamento de caixa das organizações. Em contextos de crise, por exemplo, os efeitos da indisponibilidade de financiamento podem ser ainda maiores. Sendo assim, este trabalho teve como objetivo analisar os efeitos das Restrições Financeiras e crise financeira sobre as políticas de caixa, assim como, estudar os impactos de uma boa Governança Corporativa e seus efeitos sobre os níveis de caixa. Para tanto, fez-se uso de uma amostra composta por 141 empresas de capital aberto, não financeiras, obtidas por meio da base de dados Economática ${ }^{\circledR}$. O período analisado compreende 15 anos, iniciando em 2000 e se estendendo até 2014. Optou-se pela utilização do modelo de regressão com dados em painel, por meio de um painel desbalanceado, no intuito de não reduzir o número de observações utilizadas (1906). Os resultados indicaram que o nível de caixa das organizações é impactado pelo nível de sua restrição financeira, assim como por contextos de crise, onde as companhias elevaram as suas reservas de caixa sob tal cenário. De forma geral, observou-se uma associação positiva entre as variáveis de Governança Corporativa utilizadas, apesar de apenas uma ter obtido significância estatística. Logo, o resultado obtido sugere que os acionistas de uma empresa permitem ao agente gerenciar maiores reservas de caixa apenas quando há mecanismos de governança corporativa para protegê-las. Além do mais, os resultados ainda indicam que as boas práticas de governança corporativa fornecem um meio de controlar as ações dos gestores, de modo que eles utilizem as reservas de caixa apenas em situações que maximizem a utilidade dos acionistas, evitando, assim, o gasto excessivo de caixa. Em relação a adoção das normas internacionais de contabilidade (IFRS), verificou-se uma redução significativa dos níveis de caixa posteriormente a segunda fase de adoção às normas, assim como uma associação negativa e significativa entre a variável dummy representando a adoção obrigatória. Sendo assim, este trabalho contribui com a literatura científica de maneira a fornecer evidências acerca dos efeitos das restrições financeiras, uma boa governança corporativa, crise financeira e adoção do padrão IFRS sobre as políticas de caixa das companhias brasileiras.

Palavras-Chave: Cash Holdings, IFRS, Crise Financeira. 


\begin{abstract}
MANOEL, A. A. S. Cash Policies in Brazil: a study considering financial constraints and corporate governance. 2016. 101f. Dissertação (Mestrado) - Faculdade de Economia, Administração e Contabilidade de Ribeirão Preto, Universidade de São Paulo, Ribeirão Preto, 2016.
\end{abstract}

Organizations, to finance their activities, can use internal and external sources of financial resources. However, in the presence of imperfections in the capital market, as asymmetric information, agency problems and transaction costs, they can choose one over the other. The imperfections of the market coupled with financial restrictions may affect the cash management of organizations. In times of crisis, for example, the effects of the unavailability of funding may also be higher. Thus, this study aimed to analyze the effects of Financial Restrictions and financial crisis on cash holdings, as well as study the impacts of a good Corporate Governance and its effects on cash levels. To do so, we used a sample of 141 listed companies, non-financial, obtained through Economática ${ }^{\circledR}$ database. The analyzed period consists of 15 years, starting in 2000 and extending to 2014 . We opted for the use of the Panel Data regression model using an unbalanced panel, in order not to reduce the number of observations used (1906). The results indicated that the cash level of organizations is impacted by the level of its financial constraints, as well as for crisis contexts, where companies increased their cash reserves under such a scenario. In General, there was a positive association between the variables of Corporate Governance used, although only one has obtained statistical significance. Therefore, the obtained results suggest that the shareholders of a company allow the agent manage larger cash reserves only when there is corporate governance mechanisms to protect them. Moreover, the results also indicate that good corporate governance practices provide a way to control the actions of managers, so that they use cash holdings only in situations that maximize the value of shareholders, thus avoiding spending excessive cash holding. Regarding the adoption of international accounting standards (IFRS), there was a significant reduction in cash levels after the second phase adoption of the standards, as well as a negative and significant association between the dummy variable representing the mandatory adoption. Thus, this study contributes to the literature in order to provide evidence about the effects of financial constraints, good corporate governance, financial crisis and the adoption of IFRS on the cash policies of Brazilian companies.

Keywords: Cash Holdings, IFRS, Financial Crisis. 


\section{LISTA DE TABELAS}

Tabela 1. Amostra da Pesquisa ............................................................................... 52

Tabela 2. Amostra Final por Setores e Subsetores ................................................. 53

Tabela 3. Variação dos Níveis de Caixa.......................................................................... 69

Tabela 4. Média dos Níveis de Caixa das proxies de Restrição Financeira e

Governança Corporativa ....................................................................................................... 70

Tabela 5. Média dos Níveis de Caixa por Setor ....................................................... 71

Tabela 6. Estatística Descritiva ................................................................................... 72

Tabela 7. Pressupostos da Regressão .................................................................................. 73

Tabela 8. Teste Fator de Inflacionamento da Variância (VIF) ................................ 73

Tabela 9. Testes para escolha do modelo de Dados em Painel .................................. 75

Tabela 10. Modelo de Regressão de Efeitos Fixos com Erros-Padrão Robusto ..... 75 


\section{LISTA DE FIGURAS}

Figura 1. Determinantes da qualidade da informação contábil ............................... 48 


\section{LISTA DE QUADROS}

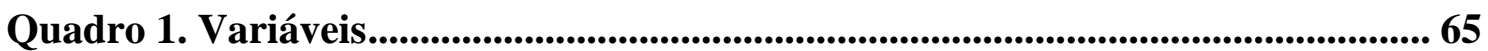


LISTA DE ABREVIATURAS E SIGLAS

$\begin{array}{ll}\text { ADR } & \text { American Depositary Receipts } \\ \text { CCL } & \text { Capital Circulante Líquido } \\ \text { CNAE } & \text { Classificação Nacional de Atividades Econômicas } \\ \text { DCP } & \text { Dívidas de Curto Prazo } \\ \text { Div } & \text { Dividendos } \\ \text { End } & \text { Endividamento } \\ \text { FCO } & \text { Fluxo de Caixa Operacional } \\ \text { GC } & \text { Geração de Caixa } \\ \text { IASB } & \text { International Accounting Standards Board } \\ \text { IBGE } & \text { Instituto Brasileiro de Geografia e Estatística } \\ \text { IFRS } & \text { International Financial Reporting Standards } \\ \text { IPCA } & \text { Índice de Preços ao Consumidor Amplo } \\ \text { KPMG } & \text { Klynveld, Peat, Marwick, Goerdeler } \\ \text { LC } & \text { Liquidez Corrente } \\ \text { Lev } & \text { Alavancagem Financeira } \\ \text { NM } & \text { Novo Mercado } \\ \text { N1 } & \text { Nível 1 } \\ \text { N2 } & \text { Nível 2 } \\ \text { OI } & \text { Oportunidades de Investimento } \\ \text { PIB } & \text { Produto Interno Bruto } \\ \text { PWC } & \text { PricewaterhouseCoopers } \\ \text { ROE } & \text { Return on Equity (Retorno sobre o Patrimônio Líquido) } \\ \text { ROA } & \text { Return on Assets (Retorno sobre o Ativo) } \\ \text { VIF } & \text { Variance Inflation Factor (Fator de Inflacionamento da Variância) } \\ \text { VPL } & \text { Valor Presente Líquido }\end{array}$




\section{SUMÁRIO}

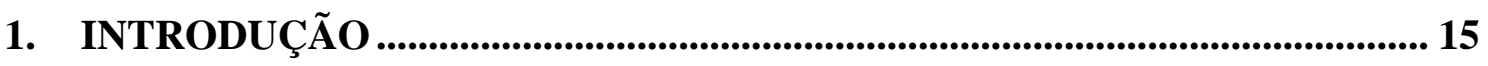

1.1. Justificativa e Contribuição ........................................................................ 17

1.2. Questão de Pesquisa e Objetivos .................................................................... 19

1.3. Estrutura do Trabalho ......................................................................................... 20

2. REFERENCIAL TEÓRICO .......................................................................................... 21

2.1. Gerenciamento de Caixa ........................................................................................... 21

2.1.1. Pecking Order .............................................................................................. 23

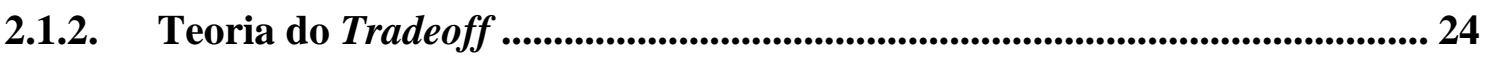

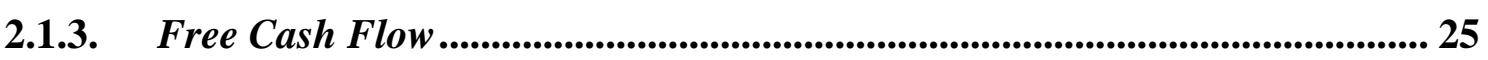

2.1.4. Modelo de Baumol e de Miller e Orr .......................................................... 26

2.2. Alguns Estudo sobre as Políticas de Caixa .......................................................... 27

2.2.1. Estudos Internacionais sobre as Políticas de Caixa.................................... 27

2.2.2. Estudos sobre Saldo de Caixa no Brasil......................................................... 34

2.3. Teoria de Agência e Assimetria Informacional .................................................... 39

2.4. Mercado de Capitais Brasileiro e Governança Corporativa ........................... 42

2.5. Restrição Financeira e Crise Financeira ............................................................ 45

2.6. Adoção das IFRS ................................................................................................. 47

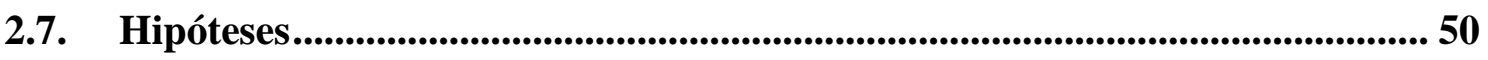

3. METODOLOGIA DE PESQUISA ............................................................. 51

3.1. População e Amostra............................................................................................................ 51

3.2. Descrição das variáveis ..................................................................................................... 54

3.2.1. Variável Dependente......................................................................................... 54

3.2.2. Critérios de Restrição Financeira ................................................................... 54

3.2.3. Variáveis de Governança Corporativa .................................................................. 57

3.2.4. Variáveis de Controle ....................................................................................6 60

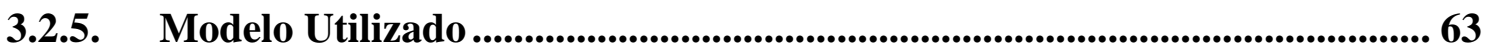

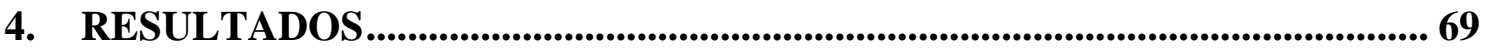

5. ANÁLISES ......................................................................................................... 77

6. CONSIDERAÇÕES FINAIS ............................................................................. 83

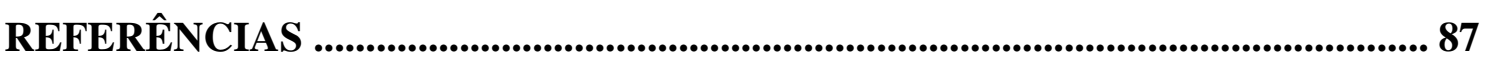

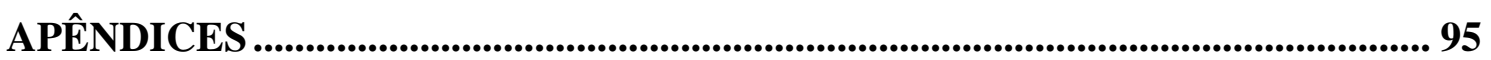




\section{INTRODUÇÃO}

No dia a dia, as organizações realizam suas atividades corriqueiras sejam elas de pagamento de fornecedores, recebimento de mercadorias, vendas de estoques, dentre outros. E nessas transações, a quantidade de caixa a ser mantido para efetuar tais atividades é um fator relevante, sendo que para Gao, Harford e Li (2013) os estudos relacionados a este tema têm recebido cada vez mais esforços da comunidade acadêmica.

Uma das decisões financeiras mais relevantes para as organizações é em relação a quanto de dinheiro manter em caixa (GAO; HARFORD; LI, 2013). De modo que, em sua essência, a decisão de manter níveis maiores de caixa ou não é uma decisão de investimento (KEYNES, 1936).

Após os trabalhos seminais de Baumol (1952), Miller e Orr (1966), e Jensen (1986) que tratam da decisão sobre manutenção do caixa, numerosos foram os trabalhos publicados que estudam os determinantes das políticas de cash holdings das organizações ao longo dos últimos anos, vide Opler et al. (1999), Dittmar, Mahrt-Smith e Servaes (2003), Almeida, Campello e Weisbach (2004), Ferreira e Vilela (2004), Han e Qiu (2007), Bates, Kahle e Stulz (2009), Nikolov e Whited (2014), Chung et al. (2015), dentre outros.

A economia brasileira, caracterizada pela alta inflação, assim como por taxas de juros elevadas, em especial, em contextos de crise, podem afetar ainda mais os níveis de caixa das organizações, onde há maior retração do consumo e reduzidas oportunidades de investimentos. E, em tais cenários, a quantia mantida no disponível nas organizações é um assunto controverso e de muito interesse por parte dos gestores (DAHROUGE; SAITO, 2013).

Segundo Modigliani e Miller (1958), as decisões de investimento de uma organização não são afetadas por suas decisões de financiamento. Porém, a teoria dos autores foi construída sobre a premissa de um mercado perfeito, onde não há custos de transação, assimetria de informação e problemas de agência, assim como em um acesso ilimitado ao crédito à uma taxa de juros livre de risco.

Considerando esta hipótese, os fundos externos seriam, portanto, substitutos perfeitos para os internos. Entretanto, a realidade não é essa, no qual observa-se o mercado brasileiro com baixo acesso ao crédito e quando de sua acessibilidade as taxas de captação são elevadas. Além disso, as imperfeições do mercado são mais graves em 
países considerados como emergentes, como o caso brasileiro e dos países da América Latina (CAMPELLO, 2012).

Posto isso, as imperfeições do mercado de capitais, como assimetria de informações, problemas de agência e custos de transação fazem, não raramente, com que as organizações optem pelo uso de fontes internas de capital em detrimento das fontes externas. Neste caso, inclusive, é de se esperar que os fluxos internos de caixa desempenhem papel mais relevante sobre os investimentos dessas organizações (KADAPAKKAM; KUMAR; RIDDICK, 1998).

Sob as limitações de um mercado imperfeito, as organizações são obrigadas a adiar ou até mesmo a desistir de projetos de investimentos quando os recursos internos são insuficientes e não há forma compatível de se obter recursos a um custo de capital acessível que não inviabilize o projeto. No intuito de contornar essas possíveis restrições, as organizações podem optar por alocar parte de seus fluxos de caixa para as suas reservas de caixa, ou até mesmo aplicar parte de seu capital em ativos mais líquidos (DAHROUGE; SAITO, 2013).

Em períodos de crise, por exemplo, quando há redução da disponibilidade de crédito, aumento das incertezas e falta de confiança no mercado financeiro, os efeitos das restrições financeiras sobre os investimentos das organizações e suas políticas de caixa podem ser ainda maiores. E sob o prisma das razões precaucionárias, a demanda por liquidez pode ser maior quando obter crédito é mais difícil (GAO; HARFORD; LI 2013).

Uma decisão de investimento dependerá diretamente das reservas de caixa de uma organização e da disponibilidade de financiamento a custos acessíveis. Por consequência, a existência de restrições financeiras é uma variável chave no entendimento das decisões de investimento de uma organização (LÓPEZ-GUTIÉRREZ; SANFILIPPO-AZOFRA; TORRE-OLMO, 2015).

A falta de caixa disponível, por exemplo, pode resultar na perda de oportunidades de investimentos, por outro lado, o excesso resulta em dinheiro ocioso e com baixa rentabilidade. Além do mais, Kim, Mauer e Sherman (1998), Opler et al. (1999), Gao, Harford e Li (2013) e Chung et al. (2015) salientam que as reservas de caixa em excesso agravam os problemas de agência, fornecendo para os gestores um montante de caixa livre acumulado que pode ser utilizado em seu próprio benefício às custas dos acionistas.

Sendo assim, as vantagens de manter reservas de caixa maiores podem ser corroídas se os interesses entre os gestores e os acionistas não estiverem alinhados (GRAHAM; LEARY, 2015). 
Beck et al. (2006) complementam ao citar que empresas em países com um mercado acionário mais desenvolvido e líquido, assim como com um sistema legal mais eficiente e maior Produto Interno Bruto (PIB) per capita, menores são as restrições financeiras. Logo, as empresas brasileiras, sitiadas em um mercado incipiente quando comparado ao americano e europeu, devem sofrer ainda mais as consequências dos obstáculos financeiros, impactando inclusive em sua gestão do caixa.

E estudos anteriores como os de Harford (1999), Opler et al. (1999), Dittmar, Mahrt-Smith e Servaes (2003) e Chung et al. (2015) citam que o nível de caixa das organizações é influenciado por diversos fatores, vide o setor da empresa, suas oportunidades de investimento, os custos de transação, razões precaucionarias, impostos, ambiente legal e normativos, incertezas dos fluxos de caixa, estrutura de propriedade, mecanismos de governança, disponibilidade de crédito a custos acessíveis, etc.

\subsection{Justificativa e Contribuição}

A motivação da realização deste trabalho reside no fato de que o estudo dos níveis de caixa mantidos pelas organizações brasileiras representa uma estratégia de gestão de risco, e pode ser uma fonte de diferenciação, em especial, em momentos de recessão econômica e contextos em que o acesso ao crédito é restrito. Aliado a isso, embora lamentável, o ambiente de crise econômica também fornece possibilidades do entendimento mais lúcido sobre o comportamento das organizações e os consequentes impactos como, por exemplo, no gerenciamento de caixa (CAMPELLO et al., 2011).

Do mesmo modo, a recente mudança do padrão contábil ao redor do mundo para as normas International Financial Reporting Standards (IFRS) também é passível de impacto nas políticas de caixa das organizações, haja vista que a mudança regulamentar contábil advindo das IFRS é uma das questões mais importante da história da contabilidade (BYARD; LI; YU, 2011; DASKE et al., 2008).

Atualmente em curso em cerca de 138 países, segundo a Fundação IFRS (2015), os efeitos e as consequências destas mudanças são temas atuais e objetos de debates e estudos por parte dos pesquisadores e dos profissionais da área (AHMED; CHALMERS; KHLIF, 2013).

Desta maneira, o presente trabalho contribui com a literatura científica de forma a fornecer evidências acerca dos efeitos das restrições financeiras, uma boa governança 
corporativa, crise financeira e adoção do padrão IFRS sobre as políticas de caixa das organizações brasileiras não financeiras listas na BM\&FBovespa.

Além disso, espera-se que este trabalho auxilie os gestores das organizações em relação a todo o processo decisório envolvendo as suas políticas de caixa, especialmente em um contex to de baixo acesso ao crédito e elevadas taxas de captação para tais recursos, uma vez que a dificuldade relacionada ao gerenciamento de caixa pelas organizações pode estar contribuindo com o número crescente de processos de recuperação judicial e até mesmo no fechamento de empresas que, por consequência, tem elevado o desemprego no Brasil.

Os mercados emergentes, segundo Uyar e Kuzey (2014), ainda possibilitam aprofundar os temas supracitados dentro do escopo deste trabalho, de maneira a explorar o ambiente regulatório mais fraco, assim como em um contexto com menor disclosure informacional e mecanismos de governança menos eficientes, o que, por sua vez, poderia levar a expropriação dos acionistas minoritários e uma maior lacuna informacional entre gestores e investidores.

Postula-se também que mediante a um melhor gerenciamento de caixa por parte dos gestores, as organizações tenham um diferencial competitivo e consigam estabelecer melhores estimativas para gerenciar o seu caixa, relacionando aos efeitos de boas práticas de governança corporativa, assim como das restrições financeiras no mercado brasileiro.

Do mesmo modo, após a adoção brasileira das IFRS, espera-se que o mercado brasileiro seja beneficiado com uma maior liquidez das ações, redução do custo de capital e maior atratividade e valorização do mercado. Acarretando, portanto, no desenvolvimento do mercado acionário brasileiro, o que inclusive poderia afetar as políticas de caixa das organizações (SANTOS; CALIXTO, 2010).

Ademais, os estudos relacionados as políticas de caixa das organizações fornece uma área promissora para estudar as implicações dos problemas de agência (TONG, 2011). E o fato deste estudo abordar diversos fatores que podem afetar as políticas de caixa das organizações brasileiras também denota a relevância do tema e da contribuição do estudo no desenvolvimento da área.

Além do mais, ao buscar avaliar a eficácia de cada mecanismo de governança corporativa na redução do comportamento oportunista e o seu consequente impacto nas reservas de caixa, este trabalho também contribuiu no entendimento sobre o tema, de maneira a sinalizar que as boas práticas de governança podem auxiliar na mitigação dos 
riscos relacionados ao mal uso do caixa por parte dos gestores (HARFORD; MANSI; MAXWELL, 2008).

Menciona-se também que as restrições financeiras, apesar de que lamentáveis, também podem favorecer a um uso mais consciente das reservas de caixa das empresas, uma vez que os gestores devem ser mais assertivos na escolha dos projetos de investimentos da organização dado a limitação dos recursos disponíveis. E caso contrário, parte de sua remuneração atrelada aos resultados da empresa pode ser corroída. Neste sentido, as restrições financeiras também podem desempenha um papel disciplinador do uso do caixa quando da presença de conflitos de agência (LUO, 2011).

Por fim, a forma de divisão das organizações, entre restritas e irrestritas, não foi devidamente aprofundada nos trabalhos brasileiros até aqui publicados, o que também permite contribuir no entendimento do comportamento do caixa dentro de cada grupo, uma vez que, as restrições financeiras representam um ponto relevante no processo de tomada de decisão dos gestores das empresas brasileiras. E dentro da literatura econômica e financeira e no próprio dia a dia das organizações, a forma pela qual as restrições de crédito afetam cada grupo econômico é uma questão central (FARRE-MENSA; LJUNGQVIST, 2016).

\subsection{Questão de Pesquisa e Objetivos}

Assim sendo, em um ambiente em que as informações são assimétricas, o mercado de capitais é incipiente e imperfeito e o acesso ao crédito é restrito surge a questão de pesquisa desse trabalho:

Quais os impactos das restrições financeiras e das práticas de governança corporativa na política de caixa das companhias brasileiras de capital aberto?

E para responder essa pergunta este estudo possui dois objetivos:

Analisar os efeitos das Restrições Financeiras, considerando também os efeitos da Crise Financeira, sobre as políticas de caixa.

Assim como, estudar os impactos da adoção das boas práticas de Governança Corporativa sobre os níveis de caixa. 


\subsection{Estrutura do Trabalho}

O presente trabalho está estruturado da seguinte maneira:

Capítulo 1 - Introdução: Seção onde é apresentado e contextualizado o problema de pesquisa, a relevância do tema proposto, assim como o objetivo e as contribuições do estudo.

Capítulo 2 - Referencial Teórico e Hipóteses: Nesta parte são apresentados os fatores que podem influenciar o Gerenciamento de Caixa: Teoria de Agência, Assimetria Informacional, Adoção das IFRS, Restrição Financeiras, Crise Financeira Internacional, assim como estudos nacionais e internacionais relacionando tais temas, de maneira a formular as hipóteses a partir das evidências empíricas documentadas nestes estudos. Do mesmo modo, são apresentadas algumas características e peculiaridades do Mercado de Capitais brasileiro;

Capítulo 3 - Metodologia de Pesquisa: Aqui são definidos os critérios de escolha das organizações da amostra e do período analisado. Além disso, explica-se a natureza dos dados, a base de dados utilizada e a forma de coleta. E, por fim, as variáveis utilizadas foram operacionalizadas no intuito de facilitar a leitura e o entendimento do modelo proposto.

Capítulo 4 - Análise dos Resultados: Neste trecho são apresentados os resultados obtidos por meio do modelo testado, assim como a interpretação dos resultados, relacionando efeitos e determinantes sobre o caixa.

Capítulo 5 - Análises: Nesta seção os resultados do modelo proposto são discutidos com a literatura destacando as concordâncias e discordâncias.

Capítulo 6 - Considerações Finais: Por último são apresentadas as considerações finais deste estudo, assim como as suas limitações e as oportunidades para novas pesquisas. 


\section{REFERENCIAL TEÓRICO}

A base teórica do presente estudo está organizada em seis subseções, no intuito de suportar a pesquisa realizada com base nas teorias existentes. Neste sentido, primeiramente são apresentados o conceito de caixa e as teorias reconhecidas pela literatura como base do seu entendimento. Após isso, discute-se a Teoria de Agência, assimetria informacional e os seus consequentes problemas e efeitos. Na sequência, contextualiza-se o mercado acionário brasileiro, assim como os efeitos da escassez de recursos e de contextos de crise econômica. Por fim, é apresentada a introdução das Normas Internacionais de Contabilidade e os efeitos desejados pelo International Accounting Standards Board (IASB) com a adoção de um padrão contábil internacional.

\subsection{Gerenciamento de Caixa}

Segundo o Comitê de Pronunciamentos Contábeis (CPC, 2010) o termo caixa se refere aqueles ativos de liquidez imediata, ou máxima liquidez, isto é, contemplando todos os recursos monetários armazenados pela organização e que são liquidados em curto prazo, tais como: saldos bancários e equivalentes de caixa.

O caixa, segundo Harford (1999), é uma ferramenta relevante que as organizações utilizam em mercados imperfeitos, onde as reservas de caixa representam uma fonte de recursos para os seus investimentos quando os recursos gerados internamente não são o bastante.

Um bom gerenciamento de caixa prove à organização o montante suficiente para ela realizar todas suas transações e honrar os seus compromissos diários, além do mais, em um contexto marcado pela competitividade um gerenciamento eficaz pode ser um diferencial para as organizações. Por outro lado, um mau gerenciamento pode resultar em destruição de valor, perda de oportunidades de negócio, custo de capital mais elevado e, inclusive em determinados níveis levando à falência.

Porém, se os mercados de capitais fossem perfeitos as políticas de caixa seriam irrelevantes para o valor de uma organização. Assim, os benefícios de manter reservas de caixas são gerados normalmente em função dos atritos de financiamento (GRAHAM; LEARY, 2015). 
Keynes (1936) elenca em seu trabalho quais seriam os três motivos principais para uma organização manter um montante mínimo no seu caixa:

i. Transação: a organização conserva certo nível de caixa para realizar e honrar suas operações correntes diárias. Sob tal modelo, as empresas realizam o seu processo de tomada de decisão sobre a quantidade necessária mantida em caixa com base nos custos de transação associados a falta de caixa ou de tê-lo em excesso;

ii. Precaução: em função da incerteza e da imprevisibilidade de recebimento dos fluxos de caixa futuros, os gestores retêm parte do caixa organizacional para eventuais imprevistos em especial, quando o custo de acessar fontes externas é demasiado alto. Bates, Kahle e Stulz (2009) complementa Keynes (1936) ao citar que o motivo de precaução também sugere que as organizações com melhores oportunidades de investimentos mantêm um volume maior de caixa devido aos choques adversos e as dificuldades financeiras são mais custosas para eles. Do mesmo modo, o motivo de precaução prevê que as organizações em indústria mais voláteis e com mais risco mantêm um nível maior de caixa;

iii. Especulação: no intuito de ter disponível um montante de capital prospetando futuras oportunidades de negócios.

Logo, o nível de caixa mínimo mantido pelas organizações refletirá as condições de mercado na qual ela está situada, o acesso ou não a fontes de financiamento, os custos dessas fontes, a volatilidade e a capacidade de geração de fluxos de caixa e a sua política para equilibrar a rentabilidade dos investimentos, sejam eles, atuais ou futuros (ALMEIDA; CAMPELLO; WEISBACH, 2004).

Sendo assim, o próximo tópico discute três modelos teóricos que segundo Ferreira e Vilela (2004) podem auxiliar no entendimento dos fatores que afetam as políticas de caixa das organizações. Depois de apresentado os três modelos, são abordados nos próximos tópicos, os modelos de Baumol e o de Miller e Orr, os efeitos da assimetria de informações e da teoria de agência, assim como sob aspectos relacionados a restrições financeiras, contextos relacionados a crise econômica e o desenvolvimento do mercado acionário brasileiro com a adoção das IFRS de forma a contemplar com alguns estudos internacionais e nacionais sobre os temas e suas influências nas políticas de caixa. 


\subsubsection{Pecking Order}

Segundo a teoria de pecking order de Myers (1984) e Myers e Majluf (1984) pode haver uma hierarquia de preferência de financiamento pelas organizações. Assim, de acordo com a demanda por recursos, uma empresa priorizará fontes internas de financiamento, por meio dos fluxos de caixa de suas operações, em segundo lugar por meio de dívida e, por fim, por meio do aumento do capital investido pelos sócios, essencialmente com a emissão de ações.

Fazzari, Hubbard e Petersen (1988) demonstram que se a desvantagem da utilização de capital de terceiros é pequena, as organizações optarão por utilizar deste recurso, porém quando o custo desse recurso é alto ou até mesmo inexiste possibilidade de obtê-lo, as organizações terão de fazer uso daqueles gerados internamente.

A diferença entre os custos de financiamento internos e externos de uma organização não pode ser diretamente observável. Entretanto, eles podem ser causados pelas informações assimétricas, conflitos entre os agentes e possíveis custos de transação (MYERS; MAJLUF, 1984).

E quanto maior as disparidades das informações maior o prêmio que os investidores exigirão para investir nessas organizações. E, de forma geral, mais informações, mesmo elas sendo privadas, é melhor do que nada. Dado isso, quanto maior a assimetria de informação entre a organização e o mercado, espera-se um custo de captação maior (EASLEY; O’HARA, 2004).

De forma complementar, Opler et al.(1999) destacam que os custos de acesso a capital de terceiros levam a organização a fazer uso do seu caixa e de seus ativos líquidos como uma forma de reserva, no intuito de não dependerem do mercado externo, já que os custos de transação de tal capital são maiores.

O fato de uma organização possuir uma ação com informações relativamente mais privadas e menos informações públicas implicam em um custo de capital próprio maior e um prêmio pelo risco exigido pelo investidor. E o valor de uma empresa ou de sua ação é menor quando as informações dela são incompletas. Por outro lado, um investidor com informações privilegiadas, por exemplo, sobre determinado ativo, enfrenta um trade-off entre risco e retorno menor (EASLEY; O'HARA, 2004).

Nesse raciocínio os autores demonstram que o custo de capital é fundamental para diversas questões corporativas dentro das organizações, inclusive influenciando a 
administração do caixa das empresas. Assim, Easley e O'hara (2004) investigam o papel da informação sobre o custo de capital. $\mathrm{O}$ argumento utilizado para tal é que as diferenças na composição das informações, sejam elas públicas ou privadas, afetam o custo do capital.

Para tanto, Easley e O'hara (2004) elencam em seu artigo que os investidores desinformados vão exigir um prêmio maior pelo risco daquelas organizações com poucas informações como as que estão tentando se inserir no mercado de capitais por problemas de seleção adversa. E que, de forma geral, mais informações, mesmo que privadas, é melhor do que nada.

Portanto, a ordem de preferência da teoria de pecking order é baseada nas informações transmitidas por cada mecanismo de financiamento, sendo que a prioritária é àquela menos sensível à informação transmitida. Logo, essa hierarquia de financiamento auxilia as organizações na redução da assimetria de informações e dos custos de transação (MYERS; MAJLUF, 1984; MYERS, 1984).

Sendo assim, esta teoria parte do pressuposto que os gestores de uma organização são melhores informados, por exemplo, do que os acionistas e de seus atuais e futuros investidores. Assim, sob o prisma da teoria de pecking order as organizações podem abrir mão de bons projetos se os fundos gerados pela própria organização não forem suficientes e se a assimetria de informações, segundo Drobetz, Grüninger e Hirschvogl (2010) for "proibitiva", uma vez, que as organizações preferem acessar mercados de capitais quando o nível de assimetria informacional é menor.

Posto isso, observa-se que a teoria de pecking order não parte do pressuposto que as organizações possuem um nível de caixa alvo. De modo que, a ordem de financiamento é estabelecida no intuito de minimizar os custos de seleção adversa e de financiamento. Logo, o caixa aqui é utilizado como um “tampão" entre os lucros acumulados e as necessidades de investimento (FERREIRA; VILELA, 2004).

\subsubsection{Teoria do Tradeoff}

A teoria do tradeoff, por sua vez, é tipicamente oposta à teoria de pecking order, uma vez que nesta teoria há um nível considerado como ideal ou alvo a manter em caixa pelas organizações, de maneira a ponderar os custos e os benefícios marginais entre 
manter níveis mais elevados ou menores de caixa (FERREIRA; VILELA, 2004; MILLER; ORR, 1966).

Manter dinheiro no caixa para uma organização pode ser custoso, pois aquele valor poderia, por exemplo, estar aplicado em outro investimento. Ademais, o valor investido em caixa também reduz os indicadores de rentabilidade da organização (ALMEIDA; CAMPELLO; WEISBACH, 2004).

No entanto, manter um nível maior de caixa pode reduzir a assimetria informacional. Aliado a isso, quando da sua insuficiência de caixa as organizações podem ser obrigadas a acessarem outras fontes de financiamento ou até mesmo liquidar os seus ativos. Em contextos de crise econômica e restrição de crédito, as maiores reservas de caixa oferecem um montante de segurança contra as perdas inesperadas e os cenários desfavoráveis, podendo inclusive contribuir na manutenção das políticas de investimento da empresa sem abrir mão de projetos rentáveis (CHUNG et al., 2015; FERREIRA; VILELA, 2004).

Diante dos fatores citado, observa-se a relevância de um bom gerenciamento do tradeoff entre manter níveis menores ou maiores de caixa (ALMEIDA; CAMPELLO; WEISBACH, 2004; FERREIRA; VILELA, 2004).

Todavia, Dahrouge e Saito (2013) expõem em seu trabalho que atingir o nível ideal de caixa em uma organização brasileira pode ser complicado, haja vista a baixa participação de dívida bancária na estrutura de capital. E tal fato, por sua vez, implica em custos de transação mais elevados, o que impossibilita o ajuste ideal do caixa de forma imediata.

Por outro lado, os níveis de caixa de uma organização podem ser decisões secundárias em uma firma em detrimento a outros fatores como a redução dos custos de transação. Todavia, estes pontos não são mutualmente exclusivos, uma vez que tais fatores aliados de outros itens também influenciam os níveis de caixa das empresas (JIANG; LIE, 2016; FERREIRA; VILELA, 2004)

\subsubsection{Free Cash Flow}

Jensen (1986) em um outro trabalho sugere que os gestores possuem incentivos para aumentar as reservas de caixa da companhia em que trabalham, de maneira a ter um 
montante maior de caixa sob seu controle e ganhar poder discricionário sobre o processo de tomada de decisão de investimento.

Porém, Jensen (1986) complementa dizendo que quando há uma maior quantidade de caixa disponível para os gestores, eles podem, por exemplo, usar esse montante em projetos mais arriscados ou até mesmo com Valor Presente Líquido (VPL) mais baixo. Desse modo, os acionistas de uma organização irão restringir o acesso ao caixa livre disponível para mitigar os problemas de agência.

Assim, a partir dessa teoria os empreendedores devem fornecer um montante de capital suficiente para que os gestores realizem de forma eficiente todos os projetos bons para a companhia. Por outro lado, o montante não deve ser em excesso, de modo que, o gestor não se beneficie às custas dos empreendedores (HARFORD; MANSI; MAXWELL, 2008).

Os acionistas de uma organização com operações em ambientes de poucas informações, portanto, não deixarão uma grande quantidade de caixa disponível para os gestores devido aos custos excessivos para monitorar as ações deles nesse ambiente. Porém, em ambientes mais transparentes e com maiores informações os acionistas de uma empresa podem disponibilizar um montante de caixa maior em função da maior facilidade de monitorar os gestores e de possíveis punições no desperdício de dinheiro (CHUNG et al., 2015).

\subsubsection{Modelo de Baumol e de Miller e Orr}

Quando do ensino de temas relacionados as políticas de caixa das organizações durante a graduação, os modelos de Baumol (1952) e Miller e Orr (1966) são aqueles tradicionalmente ensinados em disciplinas que envolvem o tema administração de caixa. O primeiro modelo, diz respeito ao conceito de lote econômico de compra, e é aplicado quando da existência de entradas periódicas e saídas constantes de recursos. Um dos exemplos práticos, quando da explanação do modelo, é o caso de uma família que é remunerada apenas em uma determinada data do mês, e as saídas dos recursos podem ocorrer diariamente (BAUMOL; 1952).

O modelo de Miller e Orr (1966), por sua vez, considera que as entradas e as saídas dos recursos podem ser diárias e inclusive, sofrer oscilações. Desta maneira, este modelo 
não parte do pressuposto de entradas em caixa conhecidas, o que, por outro lado, difere do modelo de Baumol (1952).

Logo, Miller e Orr (1966) em seu modelo partem do pressuposto da imprevisibilidade do comportamento do caixa. Nesta linha, os autores sugerem a determinação de um saldo de caixa mínimo e outro máximo, de maneira que o nível mantido em caixa flutue entre tais valores. Deste modo, quando o montante estabelecido como mínimo for atingido, faz-se necessário o aumento dos valores ali alocados. Da mesma forma, quando o valor máximo estabelecido é alcançado, os recursos excedentes de caixa podem ser aplicados em outros investimentos.

\subsection{Alguns Estudo sobre as Políticas de Caixa}

Neste tópico são apresentados alguns estudos internacionais e nacionais sobre o gerenciamento de caixa, de forma que na primeira seção são elencados os estudos clássicos internacionais sobre o tema e alguns artigos mais recentes encontrados em bases de dados internacionais, e na segunda parte os trabalhos nacionais, especialmente os mais recentes envolvendo empresas brasileiras.

\subsubsection{Estudos Internacionais sobre as Políticas de Caixa}

Sun e Wang (2015) a título de exemplo, trouxeram evidências que a sensibilidade do fluxo de caixa é significativamente mais forte durante períodos de crise financeira, como a do subprime de 2007-2008. Sendo este efeito, positivo e significativo, mais acentuado àquelas organizações com restrições financeiras e ao grupo classificado com alto grau de precaução, sugerindo dessa forma, que o motivo precaucional é preponderante para as organizações estudadas.

Sugerindo que a crise econômica do subprime afetou as políticas de caixa das empresas utilizadas em sua amostra. Ademais, como previa uma das hipóteses do trabalho de Sun e Wang (2015) as empresas com restrições de crédito poupam uma porcentagem maior do seu fluxo de caixa durante o período, ao passo que as irrestritas não.

Kim, Mauer e Sherman (1998) em seu trabalho, prevê que os investimentos atuais de uma empresa são positivamente relacionados com a volatilidade do fluxo de caixa, fato este contrário ao observado no estudo empírico de Minton e Schrand (1999), que, por sua vez, verificou uma associação negativa a estes dois constructos. Além disto, Kim, 
Mauer e Sherman (1998) predizem que a volatilidade do fluxo de caixa futuro afeta somente aquelas organizações sem restrições financeiras.

Por outro lado, o modelo de Han e Qiu (2007) prevê que a volatilidade do fluxo de caixa é relevante apenas para as empresas com restrições. De forma geral, Han e Qiu (2007) obtiveram resultados consistentes com Minton e Schrand (1999), já que o modelo por eles utilizado prevê a volatilidade do fluxo de caixa futuro impactando negativamente sobre os investimentos atuais, e ao mesmo tempo de forma positiva sobre os investimentos atuais.

O modelo testado por Han e Qiu (2007) também separou as organizações entre restritas e irrestritas. Para fazer tal classificação os autores fizeram uso de quatro índices de restrição financeira: tamanho da empresa, pagamento de dividendos, classificação da dívida e classificação do rating.

A divisão ocorreu da seguinte forma, em relação ao pagamento de dividendos as empresas no grupo de restrições financeiras foram aquelas que não distribuíram dividendos durante o período de amostragem, já as irrestritas se elas pagaram dividendos em certos anos (HAN; QIU, 2007).

Em relação ao tamanho, elas foram classificadas como restritas se estão no quartil inferior da distribuição do tamanho. O índice de ratings de títulos (bond), por outro lado, dividiu as organizações da seguinte forma: aquelas cujos títulos foram avaliados durante o período estudado ficaram no grupo de irrestritas, enquanto as restritas os títulos não foram avaliados durante o período amostral (HAN; QIU, 2007).

E por fim, o índice final de classificação de commercial papers (notas promissórias). As organizações restritas foram as que não tiveram tais promissórias avaliadas no período, ao passo que as irrestritas são aquelas cujo papel foram avaliados no período (HAN; QIU, 2007). De forma geral, os autores observaram que o impacto da volatilidade do fluxo de caixa depende sim do estágio de restrição financeira da organização. Ademais, o foco no motivo precaucional apresenta resultados consistentes com as sugestões de Keynes (1936), demonstrando também que as restrições de financiamento podem afetar a associação entre a volatilidade do fluxo de caixa, a disponibilidade de caixa e os investimentos de uma organização.

Opler et al. (1999), por exemplo, realizaram um estudo com organizações do setor industrial dos EUA, entre os anos de 1971-1994, visando identificar quais fatores explicavam os mais variados níveis de caixa mantido pelas organizações. Após suas análises, os autores encontraram um conjunto de variáveis que poderiam estar 
relacionadas a um nível de caixa mais elevado: tais como oportunidades de investimento, lucratividade, tamanho da empresa, ativos líquidos, atividade operacional e classificação de crédito.

Além do mais, segundo Opler et al. (1999) as organizações que retêm mais caixa são aquelas com menor tamanho, negócio caracterizado como de maior risco e maiores oportunidades de crescimento. Por outro lado, as firmas com acesso ao mercado de capitais e as que possuem classificações de crédito mantêm um percentual de caixa menor.

Gao, Harford e Li (2013), por sua vez, trazem evidências, a partir de um estudo com empresas de capital aberto e fechado nos EUA entre os anos de 1995-2011, que, em média, as empresas de capital fechado mantêm quase metade do caixa $(17,17 \%)$ do que as companhias de capital aberto (9,39\%). Esse fato, segundo os autores, ocorre em função dos problemas de agência serem maiores nas organizações com ações negociadas em bolsas de valores.

Além disso, Gao, Harford e Li (2013) encontraram evidências de que as pequenas empresas mantêm um nível de caixa maior do que as maiores, assim como aquelas com um maior volume de fluxo de caixa, maior volatilidade do fluxo de caixa e maior crescimento das vendas. A alavancagem, por outro lado, apresentou uma associação negativa com o caixa. Por fim, os autores verificaram que as multinacionais apresentaram um maior nível de caixa.

Os resultados encontrados por Chung et al. (2015), por outro lado, trazem evidências de que a organizações mantem menores reservas de caixa quando a assimetria de informações é maior, ou seja, os níveis de caixa de uma organização estão negativamente associados à assimetria de informações. Suportando, dessa forma, a hipótese de custo de monitoramento dos níveis de caixa.

Aliás, os resultados de Chung et al. (2015) foram consistentes com os achados de Opler et al. (1999) e Bates, Kahle e Stulz (2009). Sendo que, as maiores reservas de caixa foram encontradas em organizações com oportunidades de crescimento superiores, analisadas pela maior razão "Market-to-Book", maior Beta, menor proporção de dívidas, menor capital circulante líquido e menores taxas de custo de aquisição.

A associação positiva entre as reservas de caixa e as oportunidades de investimento, para Chung et al. (2015), pode ser conduzida pelos custos de transação e razões precaucionárias. Assim sendo, as empresas com maiores oportunidades de investimento podem manter reservas maiores para minimizar potenciais custos de 
transação. A relação positiva entre o beta e as reservas de caixa, do mesmo modo, foi considerada consistente com a visão de que as empresas com alto risco mantem mais caixa por precaução.

Por fim, Chung et al. (2015) ainda trazem evidências que as organizações maiores retêm mais caixa em função da maior facilidade de acesso aos mercados de capitais. Assim, para Chung et al. (2015) entre as empresas com oportunidades de investimento similares, as reservas de caixa podem ser mais valiosas para aquelas que atuam em um ambiente com maiores informações assimétricas. Por consequência, manter as reservas de caixa é um nível mais alto é do interesse dos acionistas.

Sendo assim, em contraste da primeira hipótese formulada por Chung et al. (2015), este cenário sugere uma relação positiva entre os níveis de caixa de uma organização e o seu nível de assimetria de informações.

Lançando mão de outra abordagem Campello, Graham e Harvey (2010), realizaram uma survey com 1050 Diretores Financeiros (CFOs) de 39 países, no ano de 2008, englobando empresas americanas (574), europeias (192) e asiáticas (284), assim como empresas de capital aberto e fechado. Para os autores, os trabalhos na literatura de políticas de caixa geralmente utilizam as seguintes proxies para restrição financeira: empresas de menor tamanho, não pagadora de dividendos e rating de crédito pobre. E o diferencial do trabalho de Campello, Graham e Harvey (2010) reside no fato de que os autores perguntaram diretamente aos gestores se suas empresas são financeiramente restritas ou não.

Campello, Graham e Harvey (2010) verificaram que mais da metade dos entrevistados adiaram ou até mesmo cancelaram seus investimentos já planejados devido à restrição de crédito durante a crise de 2007 e 2008. Além disso, muitos CFOs das organizações classificadas como restritas ainda responderam que foi necessário vender parte de seus ativos para obter caixa, assim como algumas empresas aceleram a retirada de fundos de suas linhas de crédito por precaução de uma possível restrição futura a essas linhas. Por outro lado, a crise não afetou o nível de caixa do grupo caracterizado como sem restrições financeiras.

Aliás, Campello, Graham e Harvey (2010) também constataram que a incapacidade de contrair capital de terceiros durante o choque econômico afetou as oportunidades de investimentos de $86 \%$ das firmas restritas americanas, enquanto para as irrestritas norte-americanas esse valor chegou aos $44 \%$. Por fim, os resultados indicam 
que a crise realmente afetou os investimentos das organizações, porém de forma diferente entre as empresas.

O estudo de Ascioglu, Hegde e Mcdermott (2008), por sua vez, tenta dar um passo na direção do entendimento entre os atritos de informação e o custo de capital, mais especificamente ligando a liquidez e a assimetria de informações para as decisões de investimento e financiamento das organizações. Os autores justificam o seu estudo ao citar que eles foram os primeiros a fazerem uso de medidas diretas e teoricamente inequívocas da assimetria de informações na investigação do papel das fricções informacionais em decisões de investimento e financiamento.

Porém, assim como citado e demonstrado por Moyen (2004) é difícil identificar as organizações dentro de uma amostra com restrições de financiamento. Para o autor, o efeito das restrições financeiras sobre a sensibilidade do investimento das organizações no fluxo de caixa não é um assunto claro a partir da literatura especializada.

Desse modo, Moyen (2004) investigou em seu trabalho se as restrições de financiamento são suficientes para replicar as evidências empíricas subjacentes aos debates dos trabalhos de Kaplan e Zingares $(1997,2000)$ e Fazzari, Hubbard e Petersen (1988, 2000). Sendo o foco do trabalho no comportamento dinâmico das políticas de investimentos considerando um ambiente de informações completas.

O critério utilizado para buscar essa ligação baseou-se em dois modelos: um modelo sem restrição, em que as organizações têm acesso perfeito aos mercados financeiros externos, e um restrito. O uso dessa classificação extrema ocorreu no intuito de maximizar o efeito das restrições de financiamento sobre a sensibilidade do fluxo de caixa (MOYEN, 2004).

O autor verificou que a sensibilidade do fluxo de caixa no modelo com restrição é inferior ao modelo sem restrições. Esse fato se dá, pois, o fluxo de caixa está fortemente associado as oportunidades de investimento e em um cenário de oportunidades de investimento mais favoráveis ambas as organizações restritas e irrestritas tendem a investir mais, sendo que as empresas irrestritas emitem mais dívida para financiar as novas oportunidades (MOYEN, 2004).

Além do mais, Moyen (2004) observou a partir de suas análises que as organizações irrestritas são mais propensas a serem associadas com uma distribuição de dividendos mais baixa do que as com restrições, e que aquelas com políticas de distribuição menor, que são em maioria irrestritas. Do mesmo modo, as organizações com 
restrições de financiamento que não possuem fundos para investir são mais sensíveis as variações do fluxo de caixa.

O autor encontrou também que, de forma contrária as organizações irrestritas, as restritas de crédito em determinado momento têm de escolher entre pagar dividendos ou investir em fluxo de caixa. E isso pode explicar a associação fraca entre os fluxos de caixas das empresas restritas e os seus investimentos encontrados em seu trabalho (MOYEN, 2004).

No intuito de testar a hipótese de que se a propensão para poupar os fluxos de caixa é positiva para as organizações com restrições de financiamento, porém indistinguível para as sem restrições, Almeida, Campello e Weisbach (2004) classificaram as organizações da amostra em circo abordagens ou proxies alternativas, sugeridas pela literatura, de acordo com a probabilidade de que elas enfrentem restrições financeiras, sendo elas: política de dividendos, tamanho dos ativos, ratings da dívida, ratings do papel comercial e uma medida de índice derivada do trabalho de Kaplan e Zingales (1997), denominada de índice KZ.

Assim, Almeida, Campello e Weisbach (2004) verificaram que as organizações com restrições de crédito possuem uma associação negativa entre o seu fluxo de caixa com os choques na demanda agregada, isto é, estas organizações tendem a economizar mais em períodos de crise, enquanto que as que não possuem restrições não exibiram nenhuma mudança nos seus fluxos de caixa em respostas ao que os autores denominaram de "choques macroeconômicos".

O trabalho dos autores possibilitou a extensão do entendimento da relação entre políticas financeiras, investimento e fricção ou restrição financeira em questões relacionadas as políticas de caixa das organizações. Para os autores, há uma associação positiva forte entre os fluxos de caixa e alterações nos saldos de caixa para as organizações com restrições de acesso a créditos, o contrário ocorre para as empresas que não possuem tal restrição.

Ademais, Almeida, Campello e Weisbach (2004) sugerem que a política de caixa das organizações com restrições de crédito é positivamente influenciada pela atratividade futura de oportunidades de investimento. Dessa forma, os autores observaram que as organizações sem restrições de crédito obtiveram um nível médio de caixa e equivalentes em torno de $8-9 \%$ do ativo total, enquanto que aquelas com restrições apresentaram um nível médio de 15\% (ALMEIDA; CAMPELLO; WEISBACH, 2004). 
Os resultados, por exemplo, do trabalho de López-Gutiérrez, Sanfilippo-Azofra e Torre-Olmo (2015), que buscaram analisar a influência das restrições financeiras sobre o comportamento de investimento das empresas da Alemanha, Canadá, Espanha, França, Itália, Reino Unido e Estados Unidos, mostraram que as organizações com restrições de crédito investem menos, possuem um $Q$ de Tobin maior, fluxos de caixas e tamanho menores e uma alavancagem financeira maior do que aquelas sem restrições.

Além do mais, as organizações com restrições apresentaram um valor menor, demonstrando que elas não conseguem tirar proveito de todas as oportunidades de investimentos que elas possuem quando comparado às irrestritas. Os resultados obtidos apontaram também para uma relação negativa e estatisticamente significativa entre restrições de financiamento e oportunidades de investimento para as organizações da amostra classificadas com menores oportunidades, demonstrando, dessa forma, que essas organizações têm maior propensão a sub-investimentos (LÓPEZ-GUTIÉRREZ; SANFILIPPO-AZOFRA; TORRE-OLMO, 2015).

Por outro lado, as firmas com restrições financeiras, porém, com maiores oportunidades de investimento o resultado não foi significativo. Esse fato pressupõe que elas não realizam excesso de investimento, todavia seu comportamento de investimento é diferente daquelas com restrições. Em especial, para aquelas com maiores oportunidades, a tendência de sub-investir desaparece, permanecendo esta tendência para as empresas com menos oportunidades de investimento (LÓPEZ-GUTIÉRREZ; SANFILIPPO-AZOFRA; TORRE-OLMO, 2015).

Em se tratando das variáveis de controle, os resultados de López-Gutiérrez, Sanfilippo-Azofra e Torre-Olmo (2015) mostraram uma relação positiva e significativa para o Fluxo de Caixa, de modo que, aquelas com maior fluxo de caixa têm maior propensão a excesso de investimento. Entre as variáveis alavancagem e nível de investimento, por outro lado, a associação obtida foi negativa.

Assim, López-Gutiérrez, Sanfilippo-Azofra e Torre-Olmo (2015) suportam a hipótese do sub-investimento, porém não o comportamento de excesso de investimento. E que, de forma geral, o comportamento de investimento não é igual para todas as organizações que possuem restrição de crédito e, que a propensão a sub-investir depende das oportunidades de investimento disponíveis para as organizações. 


\subsubsection{Estudos sobre Saldo de Caixa no Brasil}

Al-Najjar (2013), por exemplo, investigou as políticas de caixa em países considerados como em desenvolvimento, englobando o Brasil, China, Índia e Rússia. Sendo que o autor teve um enfoque maior na estrutura de capital e política de dividendos. A amostra utilizada desses países contemplou 1.212 empresas não financeiras, em um painel entre 2002-2008. Da mesma forma, o autor optou por utilizar uma amostra de empresas americanas e do Reino Unido como controle, perfazendo assim um montante de 1992 firmas.

De forma geral, os resultados mostraram que as empresas da Rússia mantêm uma maior quantidade de caixa, enquanto as brasileiras mantem o nível mais baixo dentre elas, sendo que as empresas brasileiras são dependem fortemente de dívidas e pagam dividendos relativamente altos (AL-NAJJAR, 2013).

Em se tratando especificamente do Brasil, os achados se mostraram inconclusivos para os determinantes das reservas de caixa, uma vez que Al-Najjar (2013) obteve uma associação negativa entre lucratividade e os níveis de caixa, contradizendo a hipótese do autor. Do mesmo modo, obtiveram uma relação positiva entre a taxa de pagamento de dividendos e os níveis de caixa, sendo este resultado mais um que contraria a hipótese do seu trabalho.

Para o autor, este último resultado indica que as organizações menos rentáveis são capazes de pagar dividendos, para se manterem com uma reputação de pagadoras de dividendos, não são capazes de obter fundos adicionais com terceiros e, por isso, retém caixa para qualquer eventualidade no intuito de melhorar sua posição financeira. E, por fim, a alavancagem, o tamanho e a liquidez não mostraram ser determinantes significativos no entendimento das políticas de caixa das organizações brasileiras (ALNAJJAR, 2013).

O trabalho de Dahroug e Saito (2013), por sua vez, contribuiu para o entendimento sobre o tema especificamente no Brasil, de maneira a investigar como as organizações brasileiras ajustam o seu nível de caixa durante os anos da crise internacional (2008 e 2009.) Para tanto, os brasileiros utilizaram a base de dados do Sistema Economática ${ }^{\circledR}$, para a extração de dados trimestrais de uma amostra de 154 organizações, entre os anos de 2001-2011. 
A partir das análises os autores encontraram evidências que as organizações possuem tendência em aumentar o nível de cash holdings por meio da geração interna de caixa e do capital de giro. E, os custos de ajustes possuem influência significativa na tomada de decisão sobre os níveis de caixa, inviabilizando dessa forma o ajuste imediato de um ano para o outro (DAHROUG; SAITO, 2013).

Além do mais, Dahroug e Saito (2013) observaram que as organizações estudadas durante o período de recessão priorizaram o aumento do capital de giro, o que também é causado pela retração do crédito bancário do período. Dessa forma, verificaram que quanto maior o capital de giro, menor a retenção de caixa, porém, a capacidade de geração de caixa apresentou uma associação positiva com o nível de caixa.

Os autores verificaram que as organizações da amostra no período supracitado apresentaram um nível médio de caixa de 6,5\% dos ativos. Além disso, os resultados apontaram que as organizações brasileiras estudadas perseguem um nível alvo de caixa a um nível de $1 \%$, porém, o ajuste encontrado é mais lento do que em certos países, tais como Alemanha, França e Reino Unido. E isso se dá em função da baixa disponibilidade de crédito e pelo alto custo do financiamento bancário (DAHROUG; SAITO, 2013).

A variável tamanho, como esperado, também apresentou um sinal negativo, demonstrando que quanto maior a empresa menor é o nível de caixa mantido por ela. Fato esse que corrobora os achados dos estudos de Miller e Orr (1966), Harford (1999), Opler et al. (1999) e Dittmar, Mahrt-Smith e Servaes (2003).

De forma contrária aos resultados obtidos nos trabalhos de Kim, Mauer e Sherman (1998), Opler et al. (1999) e Ozkan e Ozkan (2004), a alavancagem obteve uma associação negativa com o nível do caixa. A variável Market-to-book, representando as oportunidades de crescimento, do mesmo modo, não apresentou significância estatística (DAHROUG; SAITO, 2013).

Outro ponto que destoou da literatura internacional no trabalho de Dahroug e Saito (2013) foi o fato de que quanto mais elevada a geração de caixa maior a retenção de caixa das organizações, resultado esse ao nível de 1\%. E, por fim, a variável Ldebt (Dívida de Longo Prazo dividido pelo Ativo Total), representando a estrutura de vencimento da dívida, apresentou uma associação positiva com o caixa, isto é, quanto maior a quantidade de financiamento de longo prazo, maior o nível de caixa das organizações da amostra.

Por outro lado, os resultados também demostraram que as organizações com mais liquidez tendem a reduzir o nível de dinheiro e os investimentos em momentos de 
recessão econômica e talvez, isso se dê em função de não encontrarem oportunidades de investimento em tal contexto (DAHROUG; SAITO, 2013).

O estudo de Aldrighi e Bisinha (2010) é outro que buscou estudar se as organizações brasileiras com ações comercializadas na Bovespa enfrentam restrições de crédito. Visando solucionar o seu objetivo, os autores fizeram uso do Sistema Economática $^{\circledR}$, para coletar os balanços patrimoniais de 565 organizações para os anos de 2001-2005. Após algumas exclusões, restaram 247 em um painel não balanceado.

Em um primeiro momento, os autores estimaram a demanda das organizações por investimento por meio do $Q$ de Tobin, definido pelos autores como a razão entre o valor de mercado de uma companhia e o valor de reposição dos seus ativos fixos. Tal proxy foi utilizada para controlar as oportunidades de investimento, e o fluxo de caixa, por sua vez, como proxy para grau de restrição financeira. Desse modo, dois modelos em painel foram estimados com as duas proxies supracitadas, tendo a demanda por investimento como variável dependente do estudo.

Para separar as organizações de acordo com o potencial de cada uma a restrições de capital os autores optaram pelo critério do tamanho das organizações. Após a escolha do critério, as empresas foram agrupadas em três grupos: empresas pequenas, com faturamento bruto total abaixo de R $\$ 1$ bilhão; empresas grandes, com faturamento acima de $\mathrm{R} \$ 5$ bilhões/ano; e por fim, empresas médias, com um faturamento entre os valores supracitados.

Os resultados da proxy fluxo de caixa apresentaram significância estatística para o grupo de empresas classificadas como de grande e médio porte, e os resultados sugerem que os investimentos das organizações de maior tamanho são mais sensíveis ao fluxo de caixa.

Kirch, Procianoy e Terra (2014) buscaram testar a relação entre as restrições de crédito e a demanda por investimentos das companhias brasileiras. Nesse intuito, fizeram uso de uma amostra de 342 empresas, entre 1996 e 2009.

Para classificar as organizações de sua amostra entre restritas e irrestritas, Kirch, Procianoy e Terra (2014) utilizaram o critério tamanho dentro de cada setor de atividade, de modo que o grupo restrito foi aquele pertencente aos 3 decis inferiores do ativo total, e o irrestrito nos 3 decis superiores de cada setor.

Dentre os principais resultados obtidos por Kirch, Procianoy e Terra (2014), menciona-se que a demanda por investimentos é sensível a disponibilidade de financiamento para o grupo classificado como restrito. Além disso, os dois critérios de 
classificação de acordo com o setor e Ativo Total, indicaram que há diferenças no comportamento entre os grupos a respeito à decisão de investimento, onde no irrestrito, as organizações, a demanda por investimentos, em geral, é sensível somente às oportunidades de investimento. No restrito, por outro lado, a demanda por investimentos é sensível à existência de recursos internos

Outro trabalho nacional, porém, mais recente é o de Ghani, Martelanc e Kayo (2015). Segundo os autores as organizações que não possuem capital em bolsa teriam, em tese, que apresentar um nível maior de restrição de financiamento em função da maior assimetria de informação dela frente ao mercado. Partindo desse pressuposto, os brasileiros tiveram como objetivo verificar por meio da abordagem do cash flow sensitivity se as organizações de capital fechado apresentavam maior restrição de crédito em relação as organizações de capital aberto.

Os autores, posteriormente, complementam sua hipótese citando o trabalho de Fazzari, Hubbard e Petersen (1988), onde estes afirmam que caso o fluxo de caixa esteja relacionado com o investimento, pode haver indícios de restrição de financiamento, tendo em vista que a organização faça uso de fontes internas de capital para financiar as suas atividades.

Dessa forma, objetivando testar a sua hipótese Ghani, Martelanc e Kayo (2015) fizeram uso de uma amostra de 852 organizações, sendo ela composta por 688 organizações de capital fechado e 164 de capital aberto, para o período de 2007-2010. A amostra, por sua vez, foi disponibilizada pela Fipecafi (Fundação Instituto de Pesquisas Contábeis, Atuariais e Financeiras), e a análise se deu por painel dinâmico.

Como proxy para a fluxo de caixa Ghani, Martelanc e Kayo (2015) utilizaram o EBITDA (obtida pela soma do Lucro Operacional com a Depreciação). Os resultados encontrados, todavia, demonstraram não haver diferença estatisticamente significativa na restrição de crédito entre as empresas de capital aberto e fechado, rejeitando dessa forma, a hipótese no trabalho apresentada. As evidências encontradas, sugerem, então, que o grau de assimetria de informações para as organizações brasileiras da amostra independe se a organização é de capital aberto ou fechado.

No mesmo ano, Chalhoub, Kirch e Terra (2015), buscaram identificar as principais fontes do caixa retido pelas organizações brasileiras com ações negociadas na BM\&FBovespa, utilizando para tal uma amostra de 655 companhia entre os anos de 1995-2013 com informações anuais. Os autores possuíam como objetivos específicos verificar se há diferenças no comportamento entre as empresas classificadas como 
restritas e irrestritas seguindo os critérios tamanho e setor, e identificar se há semelhanças ou diferenças empíricas entre as companhias brasileiras e americanas.

A forma de classificação ocorreu ano a ano, de maneira que as empresas dos 3 decis inferiores do ativo total (proxy para tamanho) foram classificadas como restritas, e aquelas dos 3 decis superiores como irrestritas, assim como utilizado por Kirch, Procianoy e Terra (2014). Chalhoub, Kirch e Terra (2015) esperam que o grupo classificado como restrito tenham mais dificuldades de acesso ao mercado acionário e o de dívidas, o que para eles denotaria uma maior dependência dos fluxos de caixa gerados internamente.

Dentre os principais resultados obtidos por Chalhoub, Kirch e Terra (2015), menciona-se o fato de que o fluxo de caixa operacional representou a principal fonte de caixa retido no Brasil, seja para o grupo classificado como restrito ou irrestrito. Além do mais, os autores obtiveram evidências de que as empresas do grupo restrito encontraram dificuldades em acessar outros mercados externos por meio de dívidas e ações, assim como a emissão de ações só apresentou efeito sobre os níveis de caixa no grupo classificado como irrestrito.

Chalhoub, Kirch e Terra (2015) ainda encontraram que as razões precaucionarias afetam de modo diferente os grupos restritos e irrestritos, de maneira que para o primeiro grupo verificou-se que o fluxo de caixa operacional é afetado pelo risco. O segundo, por sua vez, não observou-se tal influência. Por fim, os brasileiros ainda evidenciaram que os resultados obtidos podem ser interpretados em função de o Mercado Acionário Brasileiro ser menos desenvolvido do que o Americano.

Além de Ghani, Martelanc e Kayo (2015) e Chalhoub, Kirch e Terra (2015), Arata, Sheng e Lora (2015) também publicaram um artigo em 2015, em que buscaram evidências sobre os efeitos do grau de internacionalização sobre os níveis de caixa de empresas brasileiras e mexicanas, entre os anos de 2006 e 2010.

Os resultados encontrados pelos autores sugeriram que o grau de internacionalização é um fator determinante nos níveis de caixa mantido pelas organizações, de maneira que o nível aumenta quadraticamente conforme o grau de internacionalização cresce (ARATA; SHENG; LORA, 2015).

Mais recentemente, Tortoli e Moraes (2016) buscaram analisar os fatores impactantes sobre o saldo de caixa das companhias brasileiras não financeiras pertencentes ao mercado acionário brasileiro. Visando tal objetivo, fizeram uso de uma 
amostra de 131 empresas para o período de 2007-2013, utilizando o modelo de regressões por meio de um painel balanceado.

Segundo Tortoli e Moraes (2016), a principal contribuição do trabalho reside na inclusão de uma variável dummy que assume o valor 1 quando da existência de captação de recursos via Banco Nacional do Desenvolvimento Econômico e Social (BNDES), e 0 do contrário. A inclusão dessa variável para o contexto brasileiro, apesar da não obtenção de significância estatística pelos autores, é relevante, haja vista, o baixo acesso a fontes de recursos no Brasil, em que o BNDES desenvolve um papel importante, ponderam Aldrighi e Bisinha (2010).

Dentre o modelo proposto por Tortoli e Moraes (2016), as variáveis Pagamento de Dividendos, variável dummy que assume o valor 1 para quando a empresa distribuiu dividendos, e do contrário 0, o Nível de Ativos Líquidos, medido pela razão entre o caixa e seus equivalentes pelo total de ativos líquidos, e a Crise Financeira, variável dummy que assume o valor 1 para os anos de 2008 e 2009 representando a crise do subprime, e 0 caso contrário, apresentaram significância estatística ao nível de $1 \%$.

Além disso, a variável dummy representando os níveis de Governança Corporativa, por meio das listagens especiais da BM\&FBovespa, onde as organizações pertencentes a tais níveis receberam o valor 1, e 0 do contrário apresentou significância ao nível de 5\%. De forma que o sinal obtido para a Governança Corporativa (+) e o Nível de Ativos Líquidos (+) foram contrários ao esperado pela literatura.

Por fim, Tortoli e Moraes (2016) atribuíram parte dos resultados encontrados à conjuntura econômica das empresas analisas, em especial, para o período de crise financeira, em que as empresas mantem saldos maiores de caixa e de seus equivalentes no intuito de evitar possíveis insolvências.

\subsection{Teoria da Agência e Assimetria Informacional}

Como observou-se nos trabalhos sobre o tema gerenciamento de caixa, um dos pontos centrais no seu entendimento é a questão dos problemas de agências e, consequentes custos de agência.

A Teoria da Agência diz respeito ao conflito de interesses e assimetria de informações entre, por exemplo, os gestores de uma organização e os atuais e possíveis 
acionistas (MYERS; MAJLUF, 1984). Para Ross (1973) a relação de agência é um dos modelos mais antigos e comuns de interação social.

Sendo que tal relação, segundo Jensen e Meckling (1976), é um contrato para o qual o principal contrata o agente para que este realize algumas atividades envolvendo a delegação de autoridade, de forma a ser remunerado pelo principal devido aos serviços prestados.

A assimetria de informações, por sua vez, implica que nem todos os participantes de um mercado tenham acesso a mesma informação. Logo, os gestores de uma organização podem ter informações estratégicas e privadas de sua empresa que podem não ser disponibilizadas a todos os investidores externos (JENSEN; MECKLING, 1976).

A assimetria informacional e a teoria de agência são temas muito estudados na literatura contábil e financeira, em especial, a partir da separação entre propriedade e controle nas empresas, o que ampliou os conflitos de interesses entre o agente e o principal. E a partir dessa relação que se desenvolve toda a estrutura da teoria de agência, dado que, em algum momento é de se esperar que o agente utilize de sua situação informacional privilegiada de maneira a maximizar a sua função utilidade (JENSEN; MECKLING, 1976).

Sendo assim, Frankel e Li (2004) complementam destacando que a assimetria de informações entre gestores e investidores é uma questão fundamental para os atuais e futuros investidores e para os observadores de mercado.

Na presença de informações assimétricas Myers e Majluf (1984) argumentam que o custo de obter capitais de terceiros é maior do que o uso dos recursos gerados internamente. Além do mais, os fundos internos permitem evitar os custos de transação associados a dívidas externas e do patrimônio líquido. Assim, as organizações que não dependem do acesso ao capital de terceiros estão em uma posição mais favorável do que aquelas que necessitam (MYERS, 1984).

As informações assimétricas entre as organizações e os investidores desinformados é uma das causas originárias de restrições de crédito e custo de capital de terceiros maiores (ASCIOGLU; HEGDE; MCDERMOTT, 2008).

Desse modo, quando o mercado não consegue distinguir entre as oportunidades de investimentos boas e ruins, há o custo de seleção adversa (AKERLOF, 1970). Assim, neste mercado a assimetria pode ser caracterizada por um contexto em que o vendedor possui plenas informações sobre o estado real de um bem, enquanto os compradores desinformados não estão a par de todas as informações. Posto isso, os compradores vão 
dispostos a ofertar apenas um montante menor do que o real valor do produto, já que não estão plenamente informados para executar um processo de decisão com maior acurácia. E a diferença entre o valor ofertado e o real é denominado como custo de seleção adversa (AKERLOF, 1970).

Contextualizando o supracitado ao mercado acionário brasileiro, pode-se dizer que os empreendedores possuem mais informações sobre a sua empresa e seus projetos do que os fornecedores de capital, o que a certo nível de assimetria informacional exigirá um prêmio elevado por parte dos financiadores para lhes fornecer recursos financeiros. Dado a taxa elevada de captação de recursos exigida, existe inclusive a possibilidade de inviabilização da realização de um projeto (EASLEY; O'HARA, 2004).

Logo, as organizações com maior assimetria informacional podem usufruir de reservas de caixa mais elevadas, haja vista os custos de captação elevados em função da elevada assimetria informacional (MYERS; MAJLUF, 1984). Portanto, quanto maior o número de informações assimétricas, mais elevados são os custos de agência e também maior é o volume de caixa mantido pelas empresas (OPLER et al., 1999).

Nikolov e Whited (2014) em um estudo mais recente, encontraram evidências de que alguns fatores do conflito de agência afetam mais as políticas de caixa do que outros. Nesse sentido, os autores citam que a participação nos lucros de uma organização é o fator mais preponderante no desalinhamento de interesse entre o agente e o principal.

Além disso, Nikolov e Whited (2014) dizem que as empresas pequenas detêm maiores níveis de caixa e os problemas de agência contribuem pouco na explicação de tal fator, e que fatores como aumento da incerteza e financiamento externo mais caro desempenham um papel mais relevante para estas organizações.

Opler et al. (1999) demonstrou em seu modelo que a assimetria de informações está associada positivamente com maiores reservas de caixa. Alguns anos depois, Cleary, Povel e Raith (2007) também apresentam um modelo que prevê que as organizações que defrontam maiores problemas de assimetria de informação invistam mais na sensibilidade do fluxo de caixa.

Assim, o nível de caixa mantido por uma organização também dependerá do ambiente de informações da empresa, seja de forma interna ou externa. E o montante de caixa disponível nas organizações é provável que seja negativamente relacionado com o grau de assimetria de informações entre os gestores da organização e seus acionistas (CHUNG et al., 2015). 
Do mesmo modo, as organizações com um número maior de informações assimétricas podem ter um custo de capital de terceiros maior. Sendo que autores como Harford (1999) e Opler et al. (1999) trazem evidências que neste contexto as organizações podem manter um maior nível de caixa.

$\mathrm{Na}$ situação em que os interesses dos gestores não estão alinhados aos dos acionistas, espera-se também que em algum momento o agente aja oportunamente, de maneira a utilizar recursos em seu próprio benefício, como em regalias, investindo em projetos que de alguma forma lhe beneficie as custas dos acionistas e até mesmo desviando recursos da organização para si próprio (JENSEN, 1976).

Logo, o agente pode ter incentivos para manter maiores reservas de caixa, dado que a disponibilidade de reservas mais elevadas facilita caso a sua intenção seja agir oportunamente. Nikolov e Whited (2014) ainda estimaram em seu estudo que os conflitos de agência aumentam as reservas de caixa na casa dos $22 \%$, demonstrando, dessa forma, a importância da consideração dos conflitos de agência nos estudos relacionados as políticas de caixa.

Gao, Harford e Li (2013) corroboram Harford (1999) e Opler et al. (1999), de forma que os resultados obtidos pelos autores demonstraram que as organizações com maiores problemas de agência mantêm níveis maiores de caixa, seja ela de capital aberto ou não.

\subsection{Mercado de Capitais Brasileiro e Governança Corporativa}

O mercado de ações brasileiro tem crescido nos últimos anos, o que tem atraído olhares de empresas e investidores dos mais variados locais. Considerado como um mercado emergente, o Brasil vem recebendo investimentos importantes em suas empresas por investidores internacionais o que vem motivando cada vez mais estudos acerca do mercado acionário brasileiro e os efeitos da assimetria informacional nessas negociações (MARTINS; PAULO, 2014).

Em uma hipótese de mercado eficiente, onde as organizações possuem acesso irrestrito a recursos de terceiros, a uma taxa sem risco, para financiar suas dívidas no momento em que precise não haveria a necessidade delas se preocuparem em gerenciar o seu caixa. Sendo assim, bastaria às organizações irem ao mercado para obterem tal recurso imediatamente a esta taxa (ALMEIDA; CAMPELLO; WEISBACH, 2004). 
Todavia, em um contexto como o brasileiro, marcado pelo baixo acesso a capital de terceiros esse tema é uma questão diária de discussão entre os gestores das organizações, uma vez, que o sistema financeiro brasileiro para Aldrighi e Bisinha (2010) pode ser caracterizado como incipiente em se tratando de fontes de financiamento de longo prazo para as organizações privadas.

Para Campello (2012) as imperfeições do mercado de capitais são mais fortes em economias emergentes uma vez que, as instituições do mercado ainda estão em seu estágio formativos. O autor complementa ao dizer que em tais mercados, não raramente, falta transparência e confiança nas instituições do mercado. Aliado a isso, cita-se também que a concentração de grande parte do volume negociado nas mãos de um número restrito de investidores, junto a baixa liquidez de alguns papéis e às deficiências do sistema de regulação ampliam os problemas de assimetria de informações no mercado brasileiro, e abre maiores possibilidades de insider trading.

Além disso, em países em que a proteção aos investidores é menor os custos de agência também são maiores e o acesso das companhias aos fundos externos será limitado em função aos seus custos mais elevados (GUNEY; OZKAN; OZKAN, 2007). Sendo assim, Chen et al. (2012) postula em seu trabalho que os níveis de caixa de uma empresa também são influenciados pelo ambiente do negócio, assim como pelos mecanismos de monitoramento das ações dos gestores.

Neste contexto insere-se as boas práticas de governança corporativa, haja vista que para Dittmar e Mahrt-Smith (2007) e Harford, Mansi e Maxwell (2008) ela impacta na maneira pela qual os gestores de uma organização utilizam o caixa e seus equivalentes, influenciando inclusive no desempenho da empresa.

E desde a separação entre propriedade e controle, os conflitos de agência se potencializaram, de modo que, os gestores buscarão satisfazer as suas necessidades privadas utilizando dos recursos corporativos em detrimento aos interesses dos acionistas (JENSEN; MECKING, 1976). Logo, Harford, Mansi e Maxwell (2008) mencionam em seu estudo que o principal limitará o acesso a maiores reservas de caixa caso não haja mecanismos robustos para controlar as ações oportunistas do agente. E a utilização de práticas de governança pode mitigar os conflitos de agência relacionados a este aspecto.

Harford, Mansi e Maxwell (2008) ainda argumentam que quando os mecanismos de governança são fracos, o excesso de caixa leva a investimentos ineficientes, e ainda por cima diminuindo o valor da empresa. No entanto, salienta-se que o principal deve fornecer um montante suficiente de capital interno para os gestores realizarem os projetos 
de investimentos avaliados tecnicamente como rentáveis, porém sem fornecer um valor excessivo que de alguma beneficie o agente às custas do principal.

Dessa maneira, caso da inexistência de mecanismos robustos de controle das ações oportunistas dos gestores, os acionistas não possuem incentivos e tampouco confiança em manter maiores reservas de caixa, mesmo em situações de restrições financeiras, em que manter saldos mais elevados pode representar um diferencial competitivo (HARFORD; MANSI; MAXWELL, 2008).

Jain, Li e Shao (2013) complementam Harford, Mansin e Maxwell (2008) ao mencionarem que estruturas de governança mais fortes tem o potencial de aumentar o valor marginal dos saldos de caixa, por meio da redução dos conflitos de agência, possibilitando assim o uso de maiores reservas de caixa, conforme a necessidade de cada organização.

Sendo assim, Denis e McConnel (2003) descrevem o construto governança corporativa como um conjunto de mecanismos que induzem os agentes de uma organização a tomarem decisões que maximizem o valor da empresa e dos acionistas. Em outras palavras, pode-se dizer que a boa governança corporativa auxilia os investidores na obtenção de um retorno justo sobre o investimento.

Oler e Picconi (2013) ainda mencionam em seu estudo que as organizações com mecanismos de governança fracos são penalizadas pelo mercado quando da manutenção de saldos.

Contextualizando o tema para o Brasil, por exemplo, no ano de 2000 foram criados os Níveis Diferenciados de Governança Corporativa, por iniciativa da Bolsa de São Paulo. De modo que, foram incluídos os Níveis 1 e 2 de Governança, e o Novo Mercado, no qual a adoção é voluntária e parte dos pré-requisitos de cada listagem (LOURENÇO; BRANCO, 2015a).

Segundo Carvalho e Pennacchi (2012), o Novo Mercado é marcado por ser muito rigoroso para muitas empresas brasileiras, de forma que a BM\&FBovespa também criou outras duas listas prêmios, o Nível 1, em que as práticas de governança são menos exigentes do que a do Nível 2 que, por sua vez, é mais semelhante ao Novo Mercado, porém permite as empresas listadas emitir ações preferenciais.

As evidências do trabalho de Carvalho e Pennacchi (2012) sugerem que as listas supracitadas representam um mecanismo de ligação credível que as organizações brasileiras podem utilizar para redução dos custos de agência e, por consequência, diminuição dos custos de captação de recursos. Assim, Lameira, Ness Júnior e Macedo- 
Soares (2007) sugerem que a melhora nas práticas de governança corporativa também impacta no valor das companhias listadas na bolsa brasileira. E estudos sobre as políticas de caixa como de Chang e Noorbakhsh (2009) destacam que a proteção ao acionista e o sistema de governança corporativa de um país afetam os níveis de caixa de uma empresa.

De forma que, Chang e Noorbakhsh (2009) indicam que um sistema de governança pobre em um país leva as organizações a manterem percentuais mais elevados no caixa, de maneira consistente aos custos de agência. Kalcheva e Lins (2007), por outro lado, obtiveram evidências em seu estudo de que a ausência de mecanismos eficazes de proteção aos acionistas, assim como a combinação dos problemas de agência e a manutenção de saldos de caixa mais elevados estão negativamente associados ao valor da empresa.

Logo, diante de todo o contexto supracitado, percebe-se a relevância da inclusão de características institucionais e legais de cada país na determinação das políticas de caixa das companhias (LA PORTA et al., 1998; GUNEY; OZKAN; OZKAN, 2007).

\subsection{Restrição Financeira e Crise Financeira}

Em decorrência das fricções financeiras não são todas as organizações que podem contar com capital de terceiros para financiar suas atividades, uma vez que os altos custos do capital externos não o fazem, nesse caso, um bom substituto para os fundos internos. Em função disso, quanto maior a restrição de crédito de uma organização, maior será o valor do caixa para ela (LYANDRES, 2007).

As restrições de crédito também levam as organizações a terem uma demanda por precaução de caixa como sugerido por Keynes (1936). Tal demanda se dá em função da imprevisibilidade dos fluxos de caixas de uma empresa e, de que diante de uma oportunidade de investimento a falta desse capital inviabilizaria algum investimento, mediante um custo de capital de terceiros elevado. Dessa forma, Gao, Harford e Li (2013) trazem evidências que a demanda precaucionaria e a restrições de crédito são claramente fatores triviais na política de caixa das empresas privadas.

Assim, as organizações com fricções financeiras ajustam suas políticas de caixa de forma a tentar amenizar essas restrições, direcionando, por exemplo, os fluxos de caixas futuros no aumento do capital de giro, no montante das contas de caixa e 
investimentos de curto prazo (ALMEIDA; CAMPELLO; WEISBACH, 2004; (DITTMAR; MAHRT-SMITH; SERVAES, 2003).

Kaplan e Zingales (1997) ponderam que além do capital interno, o nível de fricções financeiras também regula o nível de investimento de uma organização. Kadapakkam, Kumar e Riddick (1998) complementam ao demonstrarem que os investimentos corporativos de uma organização são afetados pela disponibilidade de fundos internos que, por sua vez, podem atenuar as consequências de uma futura restrição de financiamento.

Logo, os investimentos das organizações, que não dependem de capital externo e daquelas que disponham de crédito a taxa de juros menores, devem ser menos sensíveis ao fluxo de caixa gerado internamente do que aquelas com restrições de financiamento, dado que a disponibilidade de fundos internos para estas pode ser um fator trivial nas decisões de investimento (LYANDRES, 2007).

Sendo assim, uma organização sem restrições de crédito não teria motivo cautelar para poupar o seu caixa e equivalentes. Porém, uma companhia com restrição não poderá fazer novos investimentos no futuro sem poupar recursos agora e reduzir os atuais investimentos. Desse modo, frente a maior volatilidade dos fluxos de caixa futuro as organizações restritas tendem a serem mais prudentes. E, essa cautela cria uma associação positiva entre cash holding e volatilidade do fluxo de caixa, assim como numa relação negativa entre os investimentos atuais e volatilidade do fluxo de caixa das organizações financeiramente restritas (HAN; QIU, 2007).

Assim sendo, as organizações, por exemplo, em uma situação financeira adversa seriam forçadas a adiar um investimento no intuito de criar uma gordura financeira para evitar à busca de capital de terceiros, que mesmo se lhe ofertados teriam um custo muito alto (ALDRIGHI; BISINHA, 2010).

Almeida, Campello e Weisbach (2004) em seu trabalho, demonstraram que as organizações com restrições de financiamento têm mais propensão a deixar um valor maior reservado de caixa do que aquelas com acesso a financiamentos.

Em contextos de crise, por exemplo, Campello, Graham e Harvey (2010) trouxeram evidências em uma survey realizada em 39 países, evolvendo empresas americanas, europeias e asiáticas, que mesmo empresas mais experientes tiveram dificuldades em iniciar ou até mesmo em renovar suas linhas de crédito durante a crise do subprime. Se este fato ocorreu em mercados mais desenvolvidos, é de se esperar que também ocorram no caso brasileiro. 


\subsection{Adoção das IFRS}

Historicamente, os sistemas legais conjuntamente a fatores como as diferenças políticas e econômicas entre os países criou ao redor do mundo uma grande diversidade de sistemas contábeis, o que tornava a comparação entre os relatórios financeiros de organizações de países diferentes um processo árduo (SODERSTROM; SUN, 2007).

Posto essa demanda crescente, as IFRS foram instauradas no intuito de melhorar a comparabilidade, confiabilidade e transparência das informações divulgadas (ANTUNES et al., 2012). Sendo que, as IFRS são um conjunto de normas contábeis que são emitidas pelo International Accounting Standards Board (IASB), organização que, por sua vez, está sediada em Londres. O objetivo do IASB é fornecer um conjunto de regras que, idealmente, seriam aplicáveis nas demonstrações financeiras de todas as empresas do mundo (BALL, 2006).

No Brasil, mediante a Lei 11.638/2007, entraram em vigor no ano de 2008 de forma parcial as Normas Internacionais de Contabilidade (International Financial Reporting Standards - IFRS). De modo que, após o período de transição inicial foram adotadas obrigatoriamente o conjunto completo das IFRS em 2010. Sendo que, as normas internacionais se tornaram obrigatórias para as demonstrações financeiras consolidadas e individuais de todo tipo de sociedade (SANTOS; PONTE; MAPURUNGA, 2014).

A Europa, diferentemente do Brasil adotou as normas de forma plena no ano de 2005. E a adoção por parte do continente europeu representou um marco relevante para a contabilidade, dado que no respectivo ano 7000 organizações de 25 países do continente passaram a adotar as IFRS (IFRS, 2015).

Assim como a empresas europeias, as organizações da África do Sul, Austrália, Hong Kong e a Nova Zelândia adotaram as IFRS a partir de 2005. De modo que o número de países adotantes vem crescendo ao longo dos últimos anos, perfazendo em abril de 2015 um total de 138. Sendo que, dentre as economias consideradas como desenvolvidas, somente os EUA, Índia e Japão não aderiram as IFRS ou normas substancialmente convergentes até a presente data (IFRS, 2015).

A missão da Fundação IFRS (2015) com a adoção das normas é desenvolver um conjunto de normas internacionais que beneficiem os usuários com informações mais transparentes em mercados financeiros mais eficientes. Do mesmo modo, espera-se uma redução da assimetria informacional e na comparabilidade das informações financeiras 
entre organizações de diversos países, facilitando, por consequência, as análises dos usuários destas informações, contribuindo na eficiência econômica, na alocação dos recursos escassos, assim como na redução dos custos de capital e de reporte.

Aliado a isso, outros possíveis benefícios das normas encontrados na literatura são: redução das barreiras de investimento internacionais, mercados com maior liquidez e com maior eficiência (BROWN, 2013). A melhora na qualidade das demonstrações financeiras ocorreria em função do uso de critérios de reconhecimento e mensuração que refletiam de melhor forma a realidade das firmas, assim como no fornecimento de informações em notas explicativas. (DASKE, 2006; LOURENÇO; BRANCO, 2015b).

Assim, com a adoção das IFRS espera-se que as informações financeiras sejam mais precisas, completas e transparentes. Do mesmo modo, ao eliminar muitas diferenças internacionais nas normas contábeis e por padronizar os relatórios financeiros espera-se que os relatórios financeiros das organizações sejam mais comparáveis internacionalmente. Além do mais, a adoção das IFRS pode reduzir os custos para os investidores no processamento das informações financeiras, o que aumentaria a eficiência dos mercados de capitais (BALL, 2006).

Assim sendo, espera-se que a assimetria informacional seja reduzida, assim como os problemas decorrentes dos problemas de agência, o que poderia inclusive reduzir os custos de capital de terceiros (BALL, 2006).

Figura 1. Determinantes da qualidade da informação contábil

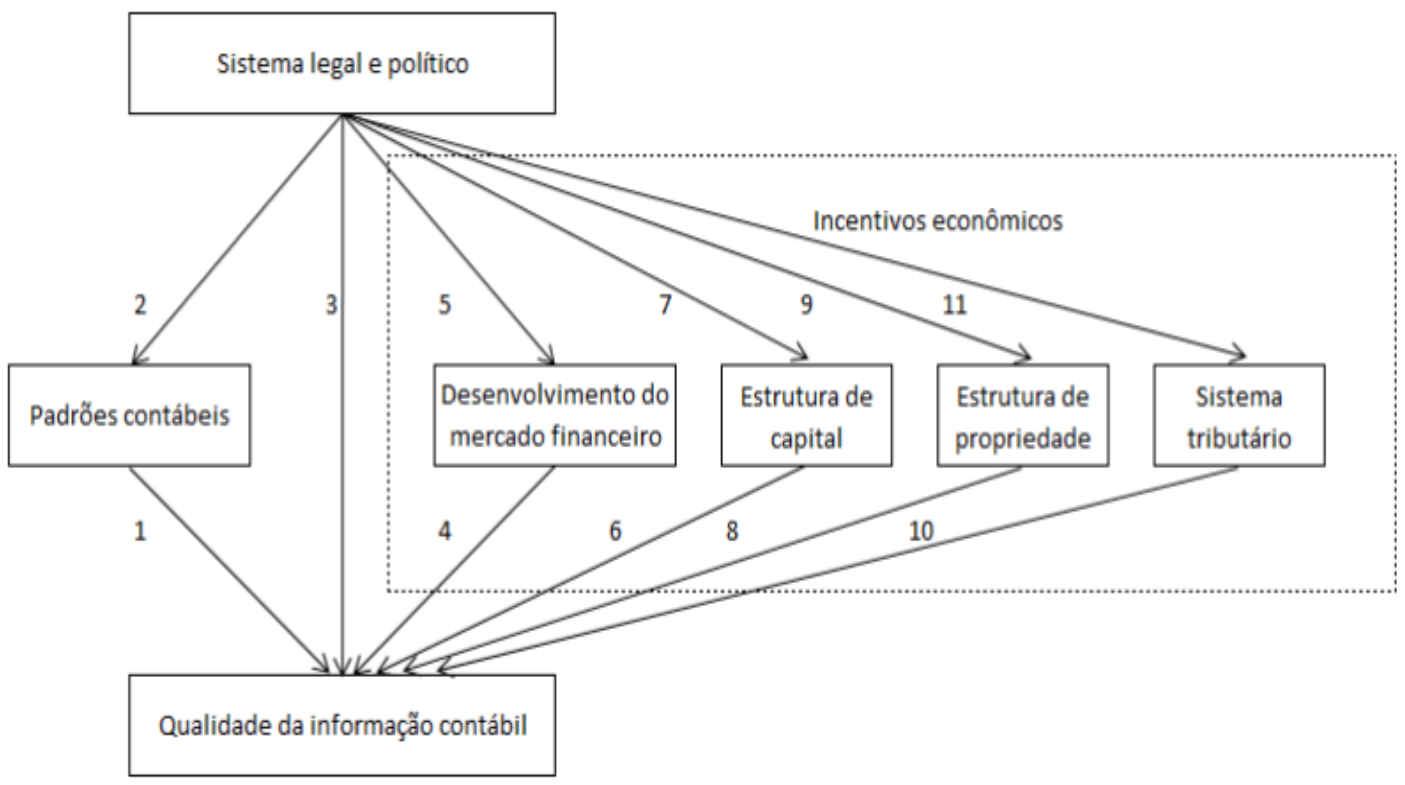

Fonte: Tradução própria a partir de Soderstrom e Sun (2007, p. 688). 
Para Soderstrom e Sun (2007) diversos são os fatores que podem influenciar as informações contábeis. Assim a partir do quadro esquemático elaborado pelos autores (Figura 1), pode-se observar detalhadamente que além do padrão contábil, fatores como o sistema legal e político, e os incentivos à divulgação também afetam a qualidade da informação contábil.

Logo, a adoção de um novo conjunto de normas é apenas um dos determinantes da qualidade da informação contábil. Posto isso, os resultados mistos encontrados na literatura sobre as consequências da adoção das IFRS ao redor do mundo, em relação por exemplo, a melhora na qualidade e comparabilidade da informação financeira e contábil, redução nos custos de agência e na assimetria informacional estão atrelados também aos demais fatores citados por Soderstrom e Sun (2007) em seu trabalho. O que não impossibilita, ainda segundo os autores, que questões metodológicas destes trabalhos também influenciem os resultados divergentes encontrados na literatura.

Daske et al. (2013) elenca em seu trabalho que os benefícios da adoção das IFRS na liquidez de um mercado e na redução do custo de capital ocorre apenas nas empresas adotantes "de modo sério" (serious adopters) e não naquelas que adotam as IFRS "apenas como rótulo" (label adopters).

Aliado a isso, autores como Ball (2006), Barth, Landsman e Lang (2008), Brown (2013), Christensen, Hail e Leuz (2013), Daske et al. (2008), Lee, Walker, Christensen (2010), Li (2010), Moscariello, Skerratt e Pizzo (2014) e dentre outros salientam a importância também dos mecanismos de enforcement na obtenção de resultados positivos na adoção das IFRS.

Assim, as motivações subjacentes a adoção das normas também são relevantes, haja vista que algumas empresas podem fazer as alterações para as normas apenas como um título, de modo a não fortalecer o seu compromisso com a transparência e de não realizar alterações significativas em seu material de comunicação com o mercado (DASKE et al., 2013).

Diante do citado, pode-se esperar que os efeitos da adoção das normas também influenciem as políticas de caixa das organizações brasileiras de capital aberto, a julgar por todos os possíveis benefícios de adoção das IFRS. 


\subsection{Hipóteses}

Diante de todo o contexto citado, em especial, tratando-se da influência do acesso ao crédito e da crise financeira e sobre os seus possíveis efeitos no gerenciamento do caixa, o presente estudo possui duas hipóteses:

H1. Empresas com diferentes níveis de restrições financeiras mantêm diferentes proporções de reservas de caixa do que as empresas irrestritas.

Observou-se no referencial utilizado que o acesso ao crédito é um fator trivial para as decisões de investimento das organizações. Portanto, as políticas de caixa das organizações também podem ser afetadas pela disponibilidade de recursos. Sendo assim, para analisar os efeitos das Restrições Financeiras, considerando também os efeitos da Crise Financeira, sobre as políticas de caixa utilizou-se três critérios encontrados na literatura que podem estar relacionados a restrição de financiamento: Dividendos, Tamanho e Idade da Empresa. De modo que, as três proxies estão detalhadas no Capítulo 3.

E em relação à Governança Corporativa, este estudo ainda possui a seguinte hipótese:

H2. As empresas com um melhor nível de governança corporativa mantêm menores níveis de caixa.

Para Dittmar e Mahrt-Smith (2007) uma boa governança corporativa melhora significativamente o valor de uma empresa, otimizando o uso de suas reservas de caixa. Além do mais, o valor de um dólar no caixa de uma empresa com boas práticas de governança é substancialmente maior do que naquelas com uma má governança corporativa. Logo, para estudar os impactos da adoção das boas práticas de governança corporativa sobre os níveis de caixa fez-se uso de cinco proxies encontradas na literatura relacionadas ao tema: Listagem Especial BM\&FBovespa, por meio da subdivisão em Nível 1, Nível 2 e Novo Mercado; Empresas Auditadas por uma das auditorias 
consideradas Big 4 (Deloitte, KPMG, PWC e Ernst \& Young) e, caso a empresa seja emissora de ADR (American Depositary Receipts).

Assim, caso a empresa pertença ao Nível 1 (N1) atribuiu-se o valor 1, e 0 do contrário. O mesmo critério foi utilizado caso a empresa esteja lista no Nível 2 (N2) e Novo Mercado (NM). Em segundo lugar, no caso da companhia ter sido auditada por uma das auditorias consideradas como BIG 4 (Deloitte, KPMG, PWC ou Ernst \& Young) atribuiu-se o valor 1, e 0 no contrário. E por fim, caso a firma possua programa de ADR (American Depositary Receipts), em qualquer nível, também utilizou-se o mesmo critério, sendo todos eles ano a ano.

Por fim, os detalhes e as descrições destas cinco proxies de Governança Corporativa, assim como as demais variáveis utilizadas neste trabalho estão elencadas no Capítulo 3.

\section{METODOLOGIA DE PESQUISA}

Neste capítulo são apresentados os dados utilizados no trabalho, em relação a amostra e população, assim como o modelo proposto, os critérios de classificação entre empresas restritas e irrestritas e a descrição das variáveis utilizadas.

\subsection{População e Amostra}

A amostra utilizada neste trabalho é composta por 141 empresas brasileiras, excluídas as instituições financeiras, listadas na BM\&FBOVESPA. A opção pela exclusão das empresas financeiras ocorreu em função de suas características próprias, em especial quanto as políticas de caixa, o que poderia enviesar as análises deste trabalho. Além disso, grande parte dos trabalhos aqui citados também excluem tais organizações, logo, a opção pela sua exclusão vem de acordo com os trabalhos já publicados sobre o tema, vide Opler et al. (1999), Ozkan e Ozkan (2004), Han e Qiu (2007), Bates, Kahle e Stulz (2009), Al-Najjar (2013), Dahroug e Saito (2013), Chung et al. (2015), Sun e Wang (2015), dentre outros.

Os dados aqui utilizados foram obtidos por meio do Sistema Economática ${ }^{\circledR}$, de forma que, foram coletadas as demonstrações financeiras consolidadas e atualizadas pela 
inflação (IPCA - Índice de Preços ao Consumidor Amplo) durante o intervalo de 20002014. A escolha das organizações da amostra ocorreu conforme a disponibilidade dos dados de todas as variáveis durante todos o período de análise.

A opção da escolha do ano de 2000 como inicial ocorreu na tentativa de analisar o maior período possível, assim como um número mais elevado de companhias listadas. Menciona-se também que caso da opção por iniciar antes de tal data, os resultados aqui obtidos poderiam ficar distorcidos em função das grandes oscilações sofridas pela economia brasileira antes desse período.

Em um primeiro momento, em função da utilização de 141 empresas listadas ao longo de 15 anos, obteve-se um total de 2115 observações. Todavia, após a retirada de Outliers, por meio do critério da amplitude inter-quartil, o montante final de observações foi de 1906, para as mesmas 141 organizações, conforme pode-se observar na Tabela 1.

Tabela 1. Amostra da Pesquisa

\begin{tabular}{lrr}
\hline \multicolumn{1}{c}{$\mathbf{2 0 0 0 - 2 0 1 4}$} & Amostra & Observações \\
Total de Empresas & $\mathbf{1 7 8}$ & $\mathbf{2 6 7 0}$ \\
(-) Empresas do setor financeiro & 30 & 450 \\
(-) Empresas com missings values para as variáveis utilizadas & 7 & 105 \\
(=) Amostra final para análise & $\mathbf{1 4 1}$ & $\mathbf{2 1 1 5}$ \\
\hline (-) Outliers (Valores Extremos) & & 209 \\
(=) Observações para análise & $\mathbf{1 9 0 6}$ \\
\hline \multicolumn{1}{c}{ Fonte: Dados da Pesquisa }
\end{tabular}

Em se tratando especificamente da classificação entre os Setores e Subsetores, segue a Tabela 2 com a própria classificação do site da BM\&FBovespa com a amostra utilizada neste trabalho.

Além das demonstrações financeiras obtidas por meio da base de dados do Sistema Economática ${ }^{\circledR}$, utilizou-se também neste estudo o próprio website da BM\&FBOVESPA, assim como o endereço digital de cada companhia da amostra, de maneira a buscar informações a respeito sob o ano de fundação de cada instituição, por qual empresa de auditoria a organização foi auditada em cada ano ao longo do período, assim como informações sobre a possibilidade de existência ou não de ações negociadas na Bolsa de Nova York, aliado ao ano de adoção e a data de encerramento de comercialização. 
Tabela 2. Amostra Final por Setores e Subsetores

\begin{tabular}{|c|c|c|}
\hline Setor & Subsetor & Frequência \\
\hline \multirow{4}{*}{ Bens Industriais } & Comércio & 2 \\
\hline & Material de Transporte & 10 \\
\hline & Serviços & 1 \\
\hline & Máquinas e Equipamentos & 10 \\
\hline & Total & 23 \\
\hline \multirow{2}{*}{ Construção e Transporte } & Construção e Engenharia & 13 \\
\hline & Transporte & 6 \\
\hline & Total & 19 \\
\hline \multirow{6}{*}{ Consumo Cíclico } & Hotéis e Restaurantes & 2 \\
\hline & Mídia & 2 \\
\hline & Tecidos, Vestuário e Calçados & 17 \\
\hline & Utilidades Domésticas & 5 \\
\hline & Viagens e Lazer & 4 \\
\hline & Comércio & 5 \\
\hline & Total & 35 \\
\hline \multirow{4}{*}{ Consumo Não Cíclico } & Alimentos Processados & 5 \\
\hline & Comércio e Distribuição & 2 \\
\hline & Produtos de Uso Pessoal e de Limpeza & 1 \\
\hline & Total & 8 \\
\hline \multirow{6}{*}{ Materiais Básicos } & Embalagens & 2 \\
\hline & Madeira e Papel & 5 \\
\hline & Mineração & 2 \\
\hline & Siderurgia e Metalurgia & 11 \\
\hline & Químicos & 3 \\
\hline & Total & 23 \\
\hline \multirow[t]{2}{*}{ Petróleo, Gás e Biocombustíveis } & Petróleo, Gás e Biocombustíveis & 2 \\
\hline & Total & 2 \\
\hline \multirow[t]{2}{*}{ Tecnologia da Informação } & Computadores e Equipamentos & 1 \\
\hline & Total & 1 \\
\hline \multirow{2}{*}{ Telecomunicações } & Telefonia Fixa & 3 \\
\hline & Telefonia Móvel & 1 \\
\hline & Total & 4 \\
\hline \multirow{4}{*}{ Utilidade Pública } & Água e Saneamento & 3 \\
\hline & Energia Elétrica & 21 \\
\hline & Gás & 2 \\
\hline & Total & 26 \\
\hline Total Geral & & 141 \\
\hline
\end{tabular}

Fonte: Elaboração Própria a partir do site da BM\&FBovespa

Do mesmo modo, após contato com o suporte da BM\&FBOVESPA, a instituição forneceu documento oficial que demonstrava todas as alterações ano a ano das companhias na listagem especial do Nível de Governança, desde uma possível entrada, saída ou alteração entre os níveis (Nível 1, Nível 2 e Novo Mercado), desde a sua criação até dados mais recentes. 


\subsection{Descrição das variáveis}

As variáveis utilizadas neste modelo vêm de acordo com a literatura sobre o tema políticas de caixa, de forma a contemplar os estudos clássicos, assim como artigos mais recentes, subsidiando a construção de todo este trabalho e modelo proposto.

\subsubsection{Variável Dependente}

Cash Holdings: A variável dependente do presente estudo é o nível de caixa, calculado pelo logaritmo natural da soma do disponível em caixa e seus equivalentes, dividido pelo total de ativos líquidos (ativo total subtraído dos caixas e seus equivalentes), seguindo as sugestões dos trabalhos de Dittmar, Mahrt-Smith e Servaes (2003) e Opler et al. (1999).

\subsubsection{Critérios de Restrição Financeira}

Uma das contribuições deste trabalho reside na classificação entre empresas restritas e irrestritas e o estudo do efeito de tal restrição sobre os níveis de caixa. Mediante a isso, classificou-se as organizações da amostra ano a ano, conforme três critérios de restrição financeira.

De antemão, salienta-se o modo de agrupamento entre firmas restritas e irrestritas financeiramente foi um dos tópicos mais polêmicos e controversos encontrados na literatura internacional. Sendo inclusive objeto de estudo de trabalhos que buscaram proxies consistentes para o constructo restrição financeira, como Fazzari, Hubbard e Petersen (1988), Kadapakkam, Kumar e Riddick (1998), Farre-Mensa e Ljungqvist (2016) que a partir dessas proxies buscaram segmentar as organizações de suas amostras em restritas e irrestritas.

Logo, responder se uma organização é restrita ou não demanda um método com precisão razoável. E, uma vez que as restrições financeiras enfrentadas por uma empresa não podem ser diretamente observáveis, os estudos na área dependem de proxies indiretas, tais como rating de crédito, pagamento de dividendos e critérios relacionados ao tamanho, idade e alavancagem (FARRE-MENSA; LJUNGQVIST, 2016). 
Porém, desde o trabalho de Fazzari, Hubbard e Petersen (1988), o método mais tradicional utilizado na literatura é categorizar as empresas da amostra em grupos conforme os seus graus de restrição, desde o maior até o menor grau de restrição. Desse modo, para testar o impacto da restrição financeira sobre o caixa mantido pelas empresas foram utilizados três critérios: Dividendos, Tamanho e Idade da Empresa.

Os dois primeiros foram utilizados por Han e Qiu (2007) em seu trabalho na classificação entre empresas financeiramente restritas e irrestritas. O terceiro, por sua vez, é a idade da empresa, que optou-se por testar neste trabalho haja vista os pressupostos teóricos da literatura sobre o tema. Para Beck et al. (2006), o tamanho da empresa e a idade são proxies eficazes na categorização de empresas restritas, de modo que organizações maiores e mais velhas relatam menos obstáculos de financiamento.

Dividendos: Fazzari, Hubbard e Petersen (1988) e Gilchrist e Himmelberg (1995) em seus trabalhos também sugerem a inclusão da variável dividendos, pois para os autores as organizações que pagam menos dividendos são mais propensas a terem restrições de acesso a créditos do que aquelas que pagam altos dividendos, de forma que elas necessitam reter mais caixa para poder financiar suas atividades.

Fazzari, Hubbard e Petersen (1988) argumentam também que as empresas que distribuem menos dividendos tem propensões maiores a terem menos acesso a financiamento do que as organizações que pagam mais. Do mesmo modo, Opler et al. (1999) e Bates, Kahle e Stulz (2009) trazem evidências de que o aumento nos níveis de caixa predomina nas organizações que não distribuem dividendos.

Em um primeiro momento pensara-se na inclusão da variável dividendos como uma dummy, conforme sugestão e uso de Opler et al. (1999), Ozkan e Ozkan (2004) e Bates, Kahle e Stulz (2009) e Kirch, Procianoy, Terra (2014), onde seria atribuído o valor 1 para a amostra/ano que pagou dividendos e, no caso contrário, 0. Entretanto, talvez essa não seja a melhor opção para o caso brasileiro.

Ademais, caso da classificação das organizações que não distribuem dividendos como restritas, sabe-se da possibilidade de incorrer em problemas das políticas organizacionais de cada empresa, uma vez que Kaplan e Zingales (1997) e Kadapakkam, Kumar e Riddick (1998) questionam o procedimento metodológico empregado de classificar as organizações que pagam poucos dividendos ou nenhum como restritas. Dessa maneira, a escolha por pagar poucos dividendos pode ser uma opção de cada companhia, de modo que elas poderiam muito bem distribuir mais os seus lucros. Logo, 
a decisão de pagar poucos dividendos, para os autores não implica necessariamente em firmas financeiramente irrestritas.

Por fim, no Brasil caso uma empresa tenha prejuízo durante o seu ano fiscal ela não é obrigada a distribuir dividendos, segundo a Lei 10.303/2001 que altera e acrescenta dispositivos na Lei 6.404/1976 que dispõe sobre as Sociedades por Ações (BRASIL, 2001). E dentre a amostra aqui utilizada de 1906 observações, 483 apresentaram um Resultado Líquido negativo (prejuízo). Desta maneira, decidiu-se por não utilizar o critério da variável dividendos como uma dummy.

Sendo assim, optou-se por inserir um critério da relação entre os Dividendos Totais pagos a cada ano em função do Lucro Líquido, o que denotaria o percentual de dividendos distribuídos a cada ano em relação ao lucro da empresa. De maneira que, espera-se que aquelas que pagam um percentual menor desta relação como dividendos sejam mais restritas, haja vista que elas precisariam reter uma fatia maior de seus lucros para cobrir eventuais imprevistos.

Tamanho: Ademais, para distinguir as organizações entre financeiramente restritas e irrestritas também se utilizou o fator tamanho, assim como Gilchrist e Himmelberg (1995), Kadapakkam, Kumar e Riddick (1998), Almeida, Campello e Weisbach (2004) e Denis e Sibilkov (2010). O argumento utilizado para a variável tamanho se dá em função dela ser uma boa medida observável de restrições financeiras, em que as empresas pequenas são geralmente menos conhecidas, mais jovens e, por consequência, mais vulneráveis as imperfeições do mercado de capitais.

Além disso, as grandes empresas têm melhor acesso ao mercado de capitais. Primeiramente por confrontarem com menores custos de transação. Em segundo lugar, por serem menos suscetíveis aos efeitos da assimetria de informações, no qual é mais provável conseguir informações atualizadas das grandes empresas do que das menores (KADAPAKKAM; KUMAR; RIDDICK, 1998). Aslan et al. (2011) complementam o exposto de Kadapakkam, Kumar e Riddick (1998) ao dizerem que quanto maior a empresa maior também o número de investidores transacionando com a companhia, assim como maior o número de ações em circulação.

Desse modo, a variável foi obtida por meio do logaritmo natural dos ativos, conforme o uso de Kadapakkam, Kumar e Riddick (1998), Almeida, Campello e Weisbach (2004), Han e Qiu (2007) e dentre outros.

De forma que, para cada ano foi efetuado o cálculo do logaritmo do ativo total, e as organizações que ficaram no quartil inferior da distribuição do tamanho foram 
classificadas como restritas, e na situação de estar no quartil superior, irrestritas (HAN; QIU, 2007). Assim, para a variável tamanho utilizou-se duas dummies, de modo a atribuir o valor 1 quando a organização se encontra abaixo do quartil inferior, e 0 do contrário. A segunda dummy, por outro lado assume o valor 1 quando a empresa está localizada no quartil superior da distribuição do tamanho, e caso contrário 0.

Idade da Empresa: Os resultados obtidos por Easley e O’hara (2004) também sugerem que o ciclo de vida de uma organização, fato este que pode afetar o custo de capital de uma empresa e, por consequência, também pode implicar no nível de caixa mantido por uma organização, já que para eles parece razoável crer que uma firma com maior tempo de existência seja mais conhecida pelos investidores.

A associação entre o nível de caixa e a idade da empresa obtido por Al-amri, Albusaidi e Akguc (2015), por exemplo, apresentou significância estatística ao nível de 1\%, com um sinal negativa, sugerindo dessa forma, que com o passar dos anos as organizações gerenciam melhor os seus fluxos de caixa e, por consequência, mantêm um nível de caixa menor.

Segundo Lyandres (2007) as empresas mais antigas já estão estabelecidas no mercado e são suscetíveis de ser caracterizadas por um menor grau de assimetria de informação e os custos de financiamento externo do que as empresas mais jovens. Dessa forma, optamos neste trabalho por testar o Logaritmo Natural da idade da empresa desde a sua fundação, como sugerido por Al-amri, Al-busaidi e Akguc (2015), por entender que tal fator possa influenciar no acesso ao crédito das organizações e, por conseguinte, nos níveis de caixa das organizações.

Assim sendo, também foi utilizado o critério de classificação entre companhias restritas e irrestritas, sugerido por Han e Qiu (2007), para o fator tamanho neste terceiro critério. Logo, fez-se uso da variável idade como duas dummies, onde as empresas localizadas para cada ano no quartil inferior, por meio do logaritmo natural da idade, foram classificadas como restritas, e aquelas acima do quartil superior, irrestritas.

\subsubsection{Critérios de Governança Corporativa}

Segundo Dittmar e Mahrt-Smith (2007) uma boa governança corporativa melhora o valor de uma empresa melhorando o uso de suas reservas de caixa. Sendo que os achados dos autores demonstram que o valor de um dólar no caixa de uma empresa é 
substancialmente menor se ela tem má governança corporativa. E tal fato se dá porque nas organizações com melhores níveis de governança, os recursos excedentes são melhor "cercados", de modo que nas outras, as reservas de caixa são dissipadas mais rapidamente.

Sendo assim, utilizou-se cinco variáveis dummies que podem impactar na qualidade da Governança Corporativa: em primeiro lugar, optou-se pela subdivisão em três dummies, no caso de a organização pertencer ao Nível 1 (N1), Nível 2 (N2) e Novo Mercado (NM), níveis estes de governança da BM\&FBovespa, em segundo caso a empresa tenha sido auditada por uma das auditorias consideradas BIG 4 (Deloitte, KPMG, PWC ou Ernst \& Young), e por fim, caso a firma possua programa de ADR (American Depositary Receipts) em qualquer nível.

Logo, para cada variável utilizada de Governança Corporativa espera-se uma associação negativa com a variável dependente caixa, haja vista que uma melhor governança pode reduzir os conflitos de agência, e os consequentes custos de agência.

Variável Dummy Lista Prêmio: Os segmentos especiais da BM\&FBovespa foram criados no ano de 2000, de modo que atualmente há três categorias prêmio: Novo Mercado, marcado pelo nível mais elevado de exigência, o Nível 2, ou intermediário e o Nível 1, considerado como o de menor nível. Todos os segmentos são marcados por regras rígidas de governança corporativa, de forma que para Ferreira et al. (2013), ao adotarem tais normas as companhias passam a ser mais atrativas, reduzindo o custo de captação e, por consequência, facilitando o acesso aos recursos de terceiros.

Assim, segundo Carvalho e Pennacchi (2012) a criação de uma lista prêmio oferece um ambiente propício para analisar a adoção por parte das empresas brasileiras a cada um dos segmentos para analisar os efeitos de uma melhor governança corporativa. Desta maneira, optou-se também por analisar tal efeito no gerenciamento do caixa das empresas brasileiras não financeiras de capital aberto.

Diferentemente de Tortoli e Moraes (2016) que utilizaram uma variável dummy quando a empresa passou a pertencer a um dos três níveis, optou-se por utilizar três variáveis dummies conforme a participação da empresa em cada um dos níveis de diferenciação. Ressalta-se que a partir da inauguração dessa listagem no ano de 2000 algumas organizações ascenderam ou até mesmo saíram dos níveis especiais, logo, este trabalho também levou em consideração os efeitos dessas alterações sobre os níveis de caixa, e as suas variações conforme o nível adotado, mediante disponibilização de uma 
planilha, por parte da BM\&FBovespa, com todas as informações e alterações das companhias sobre os três níveis ao longo dos anos.

Assim, caso uma empresa esteja listada no Nível 1 atribuiu-se o valor 1 a partir do ano de adoção até o possível ano de saída ou migração para os demais níveis, e caso contrário 0. Da mesma forma, utilizou-se o mesmo critério para o Nível 2 e o Novo Mercado.

Variável Dummy ADR (American Depositary Receipts): optou-se, do mesmo modo, inserir uma Dummy se a organização possuir programa de ADR (American Depositary Receipts) em qualquer nível, uma vez que, o acesso a outras fontes de financiamento pode resultar na utilização de um maior nível de capital de terceiros que inclusive, pode ter custos de captação mais baixo.

Costa, Paz e Funchal (2008a, 2008b) em trabalhos com companhias brasileiras utilizaram o acesso a mercados internacionais por meio da emissão de ADR (American Depositary Receipts), independentemente do nível, também como critério de restrição. A ideia dos autores ao utilizá-lo ocorre em função de que ao cumprir todos os requisitos para emitir os ADR as empresas passam a ter maior acesso ao mercado americano, o que para eles denotaria na eliminação ou redução das fricções de crédito.

E os resultados por eles obtidos demonstraram uma associação positiva e significativa para as empresas do grupo restrito (não emissoras de ADR). Logo, os autores observaram que a emissão de ADRs também poderia ser considerada como um critério de restrição financeira para as companhias brasileiras. Porém, devido à falta de observações desta mesma variável em outros artigos como critério de restrição, optou-se pela utilização como variável de governança.

Variável Dummy Big 4: por último, utilizou-se também como uma variável dummy se a organização é auditada por uma das 4 maiores empresas de auditoria do mundo, sendo elas: Deloitte, KPMG, PWC e Ernst \& Young. Caso uma companhia seja auditada por uma destas organizações ela pode estar sinalizando ao mercado que está sendo supervisionada por empresas de reputação, de modo que, as informações divulgadas podem ser de maior qualidade e confiabilidade (BEATTY, 1989). Sendo assim, se a organização é auditada por uma das 4 maiores auditorias ela recebe o valor 1 , e 0 , caso contrário. 


\subsubsection{Variáveis de Controle}

Posteriormente a inclusão das variáveis supracitadas, também se incorporou ao modelo testado as seguintes variáveis de controle: Alavancagem Financeira, Endividamento, Geração de Caixa, Oportunidades de Investimento, Retorno sobre o Patrimônio Líquido, Retorno sobre o Ativo, Liquidez, Capital Circulante Líquido, Dívidas de Curto Prazo, Dummy Crise Financeira, Dummy Indústria e Dummy IFRS.

A utilização de tais variáveis se deu no intuito de ampliar o entendimento sobre os níveis de caixa das organizações brasileiras, conforme sugestão e uso delas em artigos nacionais e internacionais. Ademais, as variáveis Tamanho e Idade, utilizadas no modelo de divisão entre firmas restritas e irrestritas também foram utilizadas como variáveis de controle. Seu uso, por outro lado, como controle ocorreu sem a utilização de dummies em caso de pertencer ao primeiro ou último quartil, de forma que foram obtidas por meio do logaritmo natural do Tamanho e Idade respectivamente, e por fim utilizadas no modelo.

Em sequência a essas duas variáveis, fez-se uso das seguintes variáveis:

Alavancagem Financeira: medido pelas dívidas de longo prazo divido pelo total de ativos. Para Han e Qiu (2007), as organizações com alto grau de alavancagem talvez precisem economizar mais caixa para pagar suas dívidas no futuro em função da maior probabilidade de dificuldades financeiras. Sugerindo dessa forma que os níveis de caixa diminuem conforme aumentam as dívidas das organizações. Assim, aquelas empresas com um maior número de ativos líquidos podem converter esses ativos em caixa e, por sua vez, manter menores níveis de caixa (AL-NAJJAR, 2013).

Desse modo, Lang, Ofek e Stulz (1996), Opler et al. (1999), Ozkan e Ozkan (2004), Han e Qiu (2007) e Al-Najjar (2013) sinalizam que há uma associação negativa entre alavancagem e níveis de caixa.

Porém, Lang, Ofek e Stulz (1996) sinaliza que a relação negativa entre alavancagem e crescimento sugere que, as organizações com alta alavancagem podem não ser capazes de tirar proveito de suas oportunidades de crescimento. Porém, tal resultado só foi significativo para aquelas organizações com um Q de Tobin baixo.

Endividamento: Optou-se também por incluir a variável endividamento, uma vez que as organizações com nível de endividamento menor possuem estímulos para reduzir a assimetria informacional e os custos de agência. Sendo assim, o cálculo da variável 
"endividamento" foi obtida por meio da razão do total de dívidas bancarias pelo total das dívidas, como sugerido por Ozkan e Ozkan (2004) eu seu estudo.

Geração de Caixa: Utilizou-se também neste trabalho uma variável de geração de caixa. Em um primeiro momento, observou-se que os trabalhos utilizaram como proxy de geração de caixa indicadores baseados em Fluxo de Caixa Operacional (FCO). Todavia, em função deste trabalho também analisar um período anterior (2000-2008) as alterações propostas pela Lei 11.638/2007 (que altera a Lei 6.404 de 1976 Lei das Sociedades Anônimas) que torna a Demonstração dos Fluxos de Caixa (DFC) obrigatória para as Sociedades Anônimas e Empresas de Grande Porte a partir de 2008 apenas.

Assim sendo, não fora possível obter esta informação anteriormente ao período de 2000 a 2008, impedindo, portanto, a construção de variáveis mais próximas ao fluxo de caixa financeiro das empresas. Na tentativa de contorna este empecilho fez-se uso de uma proxy baseada na soma do Lucro Líquido com a Depreciação, de forma que o valor resultante foi subtraído dos Dividendos Pago, e este valor final foi dividido pelo Ativo Total.

Desse modo, como sugerido por Ozkan e Ozkan (2004) e Dahrouge e Saito (2013) espera-se que os fluxos de caixas operacionais estejam positivamente relacionados as reservas de caixa.

Oportunidades de investimento: Segundo Ferreira e Vilela (2004), as organizações com maiores oportunidades de investimento têm uma demanda maior por caixa, haja vista que no caso de sua insuficiência elas podem perder projetos de investimentos valiosos. Logo, espera-se uma associação positiva entre os níveis de caixa de uma organização e suas oportunidades de investimento, uma vez que, evitarão as possibilidades de incorrerem em dificuldades financeiras.

Dessa forma, a variável aqui utilizada como proxy para oportunidades de investimento foi a mesma de Opler et al. (1999), resultante da subtração do ativo circulante pelo passivo circulante, de forma que o valor obtido foi dividido pelo total de ativos líquidos.

Em um primeiro momento pensara-se na utilização do $Q$ de Tobin como proxy para este constructo, conforme sugestão de Kadapakkam, Kumar e Riddick (1998) em seu trabalho. Todavia, devido a existência de 492 missings values para a variável "Valor de Mercado", representando 22,21\% da amostra inicial, optou-se pela utilização da proxy sugerida por Opler et al. (1999) e também utilizada por Tortoli e Moraes (2016), de modo a não restringir o número de observações. 
Rentabilidade: Segundo a teoria de Pecking Order, as organizações possuem uma ordem hierárquica na escolha de suas fontes de financiamento. Desse modo, esperase que as organizações mais rentáveis sejam mais capacitadas para pagar dividendos aos seus acionistas, assim como, para pagar suas dívidas e estocar caixa (AL-NAJJAR, 2013). De maneira a associação esperada entre a lucratividade e os níveis de caixa seja positiva.

Para tanto, optamos por utilizar duas proxies no intuito de avaliar o desempenho financeiro das organizações da amostra e não somente o Retorno sobre o Patrimônio Líquido (ROE), como Al-Najjar (2013) utilizou em seu modelo. Sendo assim, além do uso do ROE (Lucro Líquido / Patrimônio Líquido), inserimos também o Retorno sobre o Ativo (Return on Assets - ROA), obtido pela divisão do Lucro Líquido pelo Ativo Total.

Liquidez: Ainda segundo, Al-Najjar (2013) e Ozkan e Ozkan (2004), é esperado que os custos de converter ativos líquidos em dinheiro sejam menores do que outros ativos. Dessa forma, as organizações com um maior número de ativos líquidos podem converter tais ativos em dinheiro e, por sua vez, são menos propensas a acumular caixa. Desta maneira o índice de liquidez utilizado neste trabalho é o Liquidez Corrente (LC), conforme sugestão e uso de Al-Najjar (2013) em seu trabalho, por meio da divisão do Ativo Circulante pelo Passivo Circulante.

Capital Circulante Líquido: Do mesmo modo, também controlamos pelas mudanças no Capital Circulante Líquido (CCL), uma vez que ele pode ser um substituto para o dinheiro, ou mesmo concorrer para o conjunto disponível de recursos, ponderam Opler et al. (1999) e Almeida, Campello e Weisbach (2004).

Assim como utilizado por Al-amri, Al-busaidi e Akguc (2015), o cálculo do CCL foi efetuado a partir da soma dos ativos correntes, passivo correntes e caixa e equivalentes divididos pelo ativo total (AL-AMRI; AL-BUSAIDI; AKGUC, 2015).

Dívidas de curto prazo: Optamos também por controlar as mudanças na razão das dívidas de curto prazo com os ativos totais, pois da mesma forma que o capital circulante líquido, as alterações nas dívidas de curto prazo representam uma alternativa para o dinheiro, ou porque as organizações podem fazer uso de dívida de curto prazo para construir reservas de caixa (ALMEIDA; CAMPELLO; WEISBACH, 2004).

Variável Dummy Crise: A disponibilidade de crédito durante crises econômicas é menor, tornando dessa forma, financiamentos de difícil acesso. E as organizações em tal contexto de restrições de financiamento tendem a aumentar o nível do seu caixa nesses períodos em detrimento da redução dos investimentos. Por outro lado, as que não possuem tais fricções financeiras não apresentam alterações (ALMEIDA; CAMPELLO; 
WEISBACH, 2004). Assim sendo, a variável dummy aqui utilizada assume o valor 1 para os anos 2008 e 2009 e 0 nos demais períodos, assim como sugerido por Dahroug e Saito (2013) e Tortoli e Moraes (2016) em seus trabalhos.

Variável Dummy Setor: Os níveis de caixa de uma organização podem variar de acordo com os diferentes setores (GAO; HARFORD; LI, 2013). Sendo assim, também se utilizou uma variável dummy para as organizações representantes de cada setor, de modo que, as companhias da amostra foram divididas em três grupos (Indústria, Serviços e Comércio), conforme classificação da CNAE (Classificação Nacional de Atividades Econômicas) por meio do Instituto Brasileiro de Geografia e Estatística -IBGE (IBGE, 2016).

Variável Dummy IFRS: Por fim, utilizou-se neste modelo a variável dummy IFRS no intuito de controlar as mudanças causadas pela adoção das companhias brasileiras as Normas Internacionais de Contabilidade na elaboração das demonstrações financeiras. De forma que, atribui-se o valor 1 a partir do ano de 2010 (início da segunda fase brasileira da adoção das IFRS - fase obrigatória) e 0 anteriormente a isso.

Espera-se que a adoção das Normas Internacionais de Contabilidade aliado aos mecanismos de enforcement resulte em demonstrações financeiras de melhor qualidade, comparabilidade e confiabilidade. Logo, espera-se que após a adoção as organizações mantenham níveis de caixa menores.

\subsubsection{Modelo Utilizado}

Posto isso, após a descrição de todas as variáveis no tópico acima, segue conforme Equação 1 o modelo aqui utilizado:

$$
\begin{aligned}
& \left.\left.\mathrm{CASH}_{i t}=\beta_{i}+\beta_{1} \text { Div }_{i, t}+\beta_{2} \text { Restrita }_{(\text {Tam }}\right)_{i, t}+\beta_{3} \text { Irrestrita }_{(\text {Tam }}\right)_{i, t} \\
& \left.\left.+\beta_{4} \text { Restrita (Idade) }\right)_{i, t}+\beta_{5} \text { Irrestrita (Idade) }\right)_{i, t} \\
& +\beta_{6} N 1_{i, t}+\beta_{7} N 2_{i, t}+\beta_{8} N M_{i, t}+\beta_{9} A D R_{i, t}+\beta_{10} B I G 4_{i, t}+\beta_{11} \operatorname{Tam}_{i, t} \\
& +\beta_{12} \text { Idade }_{i, t}+\beta_{13} \text { Lev }_{i, t}+\beta_{14} \text { End }_{i, t}+\beta_{15} G C_{i, t}+\beta_{16} O I_{i, t} \\
& +\beta_{17} R O E_{i, t}+\beta_{18} R O A_{i, t}+\beta_{19} L C_{i, t}+\beta_{20} C C L_{i, t}+\beta_{21} D C P_{i, t} \\
& +\beta_{22} \text { Crise }_{i, t}+\beta_{23} \text { Setor }_{i, t}+\beta_{24} \text { IFRS }_{i, t}+\epsilon_{i, t} \text { (1) }
\end{aligned}
$$

Em que: 
Div = Pagamento de Dividendos, dado pela divisão do Total de Dividendos Distribuídos pelo Lucro Líquido;

Restrita $($ Tam $)=$ Variável Dummy que assume o valor 1 quando a empresa pertence ao $1^{\circ}$ Quartil da distribuição do Tamanho, dado pelo Logaritmo Natural do Ativo Total, e 0 do contrário;

Irrestrita $($ Tam $)=$ Variável Dummy que assume o valor 1 quando a empresa pertence ao $4^{\circ}$ Quartil da distribuição do Tamanho, dado pelo Logaritmo Natural do Ativo Total, e 0 do contrário;

Restrita $($ Idade $)=$ Variável Dummy que assume o valor 1 quando a empresa pertence ao $1^{\circ}$ Quartil da distribuição da Idade, dado pelo Logaritmo Natural da Idade da Empresa, e 0 do contrário;

Irrestrita $($ Idade $)=$ Variável Dummy que assume o valor 1 quando a empresa pertence ao $4^{\circ}$ Quartil da distribuição da Idade, dado pelo Logaritmo Natural da Idade da Empresa, e 0 do contrário;

$N 1$ = Nível 1, variável Dummy que assume valor 1 caso a organização esteja listada no Nível 1 de Governança Corporativa e 0 caso não esteja;

N2 = Nível 2, variável Dummy que assume valor 1 caso a organização esteja listada no Nível 2 de Governança Corporativa e 0 caso não esteja;

$N M=$ Novo Mercado, variável Dummy que assume valor 1 caso a organização esteja listada no Novo Mercado e 0 caso não esteja;

$A D R=$ American Depositary Receipt, variável Dummy que assume valor 1 caso a organização possua programa de ADR em qualquer nível, e 0 do contrário;

BIG4 = Variável Dummy que assume valor 1 caso a organização tenha sido auditada por uma das 4 maiores auditorias, e 0 do contrário;

Tam = Tamanho, dado pelo Logaritmo Natural do Ativo Total;

Idade = Idade, dado pelo Logaritmo Natural da Idade da Empresa;

$L e v$ = Alavancagem Financeira, dado pela soma do Total de Dívidas de Curto Prazo com o Total de Dívidas de Longo Prazo, sendo que o valor resultante foi dividido pelo Ativo Líquido;

End = Endividamento, dado pela soma do Total de Empréstimos e Financiamentos de Curto Prazo e de Longo Prazo, sendo que o valor resultante foi dividido pela soma do Passivo Circulante e Passivo Não Circulante; 
$G C=$ Geração de Caixa, dado pela soma do Lucro Líquido e da Depreciação, sendo o valor obtido subtraído dos Dividendos Pago, de forma que esse novo valor foi dividido pelo Ativo Total;

$O I=$ Oportunidades de Investimento, dado pela subtração do Ativo Circulante pelo Passivo Circulante, de forma que o resultado obtido foi dividido pelo Ativo Líquido;

$R O E=$ Rentabilidade sobre o Patrimônio Líquido, dado pela divisão do Lucro Líquido pelo Patrimônio Líquido;

$R O A=$ Rentabilidade do Ativo, dado pela divisão do Lucro Líquido pelo Ativo Total;

$L C=$ Liquidez Corrente, dado pela divisão do Ativo Circulante pelo Passivo Circulante;

$C C L=$ Capital Circulante Líquido, dado pela subtração do Ativo Circulante pelo Passivo Circulante;

$D C P=$ Dívidas de Curto Prazo, dado pela divisão do Passivo Circulante pelo Ativo Total;

Crise $=$ Crise Financeira, variável Dummy que assume o valor 1 para os anos de 2008 e 2009 e 0 no restante do período amostral;

Setor $=$ Setor, variável Dummy que assume o valor 1 para as empresas do mesmo setor (Indústria, Serviços e Comércio), e 0 do contrário;

IFRS = Dummy de adoção das IFRS, atribuindo o valor 1 a partir do ano de 2010, e anteriormente 0 ;

$\epsilon=$ Erro da Previsão.

Assim sendo, o Quadro 1 operacionaliza cada variável, os resultados esperados, assim como os autores que as utilizaram em trabalhos sobre o tema.

Quadro 1. Variáveis

\begin{tabular}{|c|c|c|c|c|}
\hline $\begin{array}{c}\text { Variáveis } \\
\text { Explicativas }\end{array}$ & Sigla & $\begin{array}{c}\text { Definição } \\
\text { Operacional }\end{array}$ & $\begin{array}{c}\text { Resultado } \\
\text { Esperado }\end{array}$ & Autores \\
\hline Dividendos & Div & $\begin{array}{l}\text { Total de } \\
\text { Dividendos / } \\
\text { Lucro Líquido }\end{array}$ & $\mathbf{( - )}$ & $\begin{array}{c}\text { Kim, Mauer e Sherman (1998), Opler et al. (1999), } \\
\text { Dittmar, Mahrt-Smith e Servaes (2003), Ozkan e } \\
\text { Ozkan (2004), Ferreira e Vilela (2004), Guney, Ozkan } \\
\text { e Ozkan (2007), Bates, Kahle e Stulz (2009), Al- } \\
\text { Najjar (2013), Dahroug e Saito (2013), Gao, Harford e } \\
\text { Li (2013), Kirch, Procianoy, Terra (2014), Al-amri, } \\
\text { Al-busaidi e Akguc (2015), Chung et al. (2015), Jiang } \\
\text { e Lie (2016) e Tortoli e Moraes (2016). }\end{array}$ \\
\hline
\end{tabular}




\begin{tabular}{|c|c|c|c|c|}
\hline $\begin{array}{l}\text { Variáveis } \\
\text { Explicativas }\end{array}$ & Sigla & $\begin{array}{l}\text { Definição } \\
\text { Operacional }\end{array}$ & $\begin{array}{l}\text { Resultado } \\
\text { Esperado }\end{array}$ & Autores \\
\hline $\begin{array}{l}\text { Restrita } \\
\text { (Tamanho) }\end{array}$ & $\begin{array}{l}\text { Restrita } \\
\text { (Tam) }\end{array}$ & $\begin{array}{l}\text { Variável } \\
\text { Dummy } \\
\text { (Empresa } \\
\text { Pertencente ao } \\
1^{\circ} \text { Quartil = 1; } \\
\text { Não } \\
\text { Pertencente = } \\
0)\end{array}$ & $(+)$ & $\begin{array}{c}\text { Han e Qiu (2007), Kirch, Procianoy e Terra (2014) e } \\
\text { Chalhoub, Kirch e Terra (2015) }\end{array}$ \\
\hline $\begin{array}{l}\text { Irrestrita } \\
\text { (Tamanho) }\end{array}$ & $\begin{array}{c}\text { Irrestrita } \\
(\text { Tam) }\end{array}$ & \begin{tabular}{|l} 
Variável \\
Dummy \\
(Empresa \\
Pertencente ao \\
$4^{\circ}$ Quartil = 1; \\
Não \\
Pertencente = \\
$0)$
\end{tabular} & $(-)$ & $\begin{array}{c}\text { Han e Qiu (2007), Kirch, Procianoy e Terra (2014) e } \\
\text { Chalhoub, Kirch e Terra (2015) }\end{array}$ \\
\hline $\begin{array}{l}\text { Restrita } \\
\text { (Idade) }\end{array}$ & $\begin{array}{c}\text { Restrita } \\
\text { (Idade) }\end{array}$ & 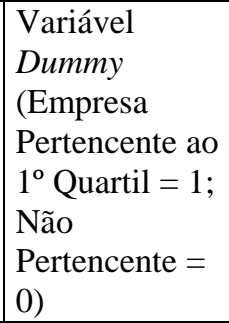 & $(+)$ & N/A \\
\hline $\begin{array}{c}\text { Irrestrita } \\
\text { (Idade) }\end{array}$ & $\begin{array}{c}\text { Irrestrita } \\
\text { (Idade) }\end{array}$ & \begin{tabular}{|l} 
Variável \\
Dummy \\
(Empresa \\
Pertencente ao \\
$4^{\circ}$ Quartil = 1; \\
Não \\
Pertencente = \\
$0)$ \\
\end{tabular} & $(-)$ & N/A \\
\hline $\begin{array}{c}\text { Dummy Nível } \\
1\end{array}$ & $\mathrm{~N} 1$ & $\begin{array}{l}\text { Variável } \\
\text { Dummy } \\
\text { (Empresa } \\
\text { Listada = 1; } \\
\text { Não Listada = } \\
0 \text { ) }\end{array}$ & $(-)$ & N/A \\
\hline $\begin{array}{l}\text { Dummy Nível } \\
2\end{array}$ & $\mathrm{~N} 2$ & $\begin{array}{l}\text { Variável } \\
\text { Dummy } \\
\text { (Empresa } \\
\text { Listada = 1; } \\
\text { Não Listada = } \\
0 \text { ) }\end{array}$ & $(-)$ & N/A \\
\hline $\begin{array}{l}\text { Dummy Novo } \\
\text { Mercado }\end{array}$ & NM & $\begin{array}{l}\text { Variável } \\
\text { Dummy } \\
\text { (Empresa } \\
\text { Listada = 1; } \\
\text { Não Listada = } \\
0 \text { ) }\end{array}$ & $(-)$ & N/A \\
\hline Dummy ADR & $\mathrm{ADR}$ & $\begin{array}{l}\text { Variável } \\
\text { Dummy } \\
\text { (Empresa } \\
\text { Emissora = 1; } \\
\text { Não Emissora } \\
=0)\end{array}$ & $(-)$ & Costa, Paz e Funchal (2008a, 2008b) \\
\hline
\end{tabular}




\begin{tabular}{|c|c|c|c|c|}
\hline $\begin{array}{l}\text { Variáveis } \\
\text { Explicativas }\end{array}$ & Sigla & $\begin{array}{l}\text { Definição } \\
\text { Operacional }\end{array}$ & $\begin{array}{l}\text { Resultado } \\
\text { Esperado }\end{array}$ & Autores \\
\hline Dummy Big 4 & BIG4 & $\begin{array}{l}\text { Variável } \\
\text { Dummy } \\
\text { (Empresa } \\
\text { Auditada por } \\
\text { Big } 4=1 \text {; Não } \\
\text { Auditada por } \\
\text { Big } 4=0 \text { ) } \\
\end{array}$ & $(-)$ & N/A \\
\hline Tamanho & Tam & $\begin{array}{l}\text { Logaritmo } \\
\text { Natural do } \\
\text { Ativo Total }\end{array}$ & $(-)$ & $\begin{array}{l}\text { Kim, Mauer e Sherman (1998), Opler et al. (1999), } \\
\text { Dittmar, Mahrt-Smith e Servaes (2003), Ozkan e } \\
\text { Ozkan (2004), Ferreira e Vilela (2004), Almeida, } \\
\text { Campello e Weisbach (2004), Han e Qiu (2007), } \\
\text { Harford, Mansi e Maxwell (2008), Bates, Kahle e } \\
\text { Stulz (2009), Denis e Sibilkov (2010), Chen et al. } \\
\text { (2012), Dahrouge e Saito (2013), Al-amri, Al-busaidi } \\
\text { e Akguc (2015), Arata, Sheng e Lora (2015), Jiang e } \\
\text { Lie (2016) e Tortoli e Moraes (2016). }\end{array}$ \\
\hline Idade & Idade & $\begin{array}{l}\text { Logaritmo } \\
\text { Natural da } \\
\text { Idade da } \\
\text { Empresa } \\
\end{array}$ & $(-)$ & $\begin{array}{l}\text { Al-amri, Al-busaidi e Akguc (2015), Al-busaidi e } \\
\text { Akguc (2015) e Jiang e Lie (2016). }\end{array}$ \\
\hline $\begin{array}{l}\text { Alavancagem } \\
\text { Financeira }\end{array}$ & Lev & $\begin{array}{l}\text { (Total Dívidas } \\
\text { de Curto Prazo } \\
\text { + Total Dívidas } \\
\text { de Longo } \\
\text { Prazo) / Ativo } \\
\text { Líquido }\end{array}$ & $(-)$ & $\begin{array}{c}\text { Lang, Ofek e Stulz (1996), Kim, Mauer e Sherman } \\
\text { (1998), Opler et al. (1999), Dittmar, Mahrt-Smith e } \\
\text { Servaes (2003), Ozkan e Ozkan (2004), Han e Qiu } \\
\text { (2007), Harford, Mansi e Maxwell (2008), Denis e } \\
\text { Sibilkov (2010), Tong (2011), Al-Najjar (2013), } \\
\text { Dahrouge e Saito (2013), Gao, Harford e Li (2013), } \\
\text { Al-busaidi e Akguc (2015), Arata, Sheng e Lora } \\
\text { (2015) e Tortoli e Moraes (2016). }\end{array}$ \\
\hline Endividamento & End & $\begin{array}{l}\text { (Total } \\
\text { Empréstimos e } \\
\text { Financiamentos } \\
\text { de Curto Prazo } \\
\text { + Total } \\
\text { Empréstimos e } \\
\text { Financiamentos } \\
\text { de Longo } \\
\text { Prazo) / } \\
\text { (Passivo } \\
\text { Circulante + } \\
\text { Passivo Não } \\
\text { Circulante) }\end{array}$ & $(-)$ & Ozkan e Ozkan (2004) e Tortoli e Moraes (2016). \\
\hline $\begin{array}{l}\text { Geração de } \\
\text { Caixa }\end{array}$ & GC & $\begin{array}{l}\text { (Lucro Líquido } \\
\text { - Dividendos } \\
\text { Pagos + } \\
\text { Depreciação) / } \\
\text { Ativo Total }\end{array}$ & $(+)$ & N/A \\
\hline $\begin{array}{c}\text { Oportunidades } \\
\text { de } \\
\text { Investimento }\end{array}$ & $\mathrm{OP}$ & $\begin{array}{l}\text { (Ativo } \\
\text { Circulante - } \\
\text { Passivo } \\
\text { Circulante) / } \\
\text { Ativo Líquido }\end{array}$ & $(+)$ & Tortoli e Moraes (2016). \\
\hline $\begin{array}{l}\text { Retorno sobre } \\
\text { o Patrimônio } \\
\text { Líquido }\end{array}$ & ROE & $\begin{array}{l}\text { Lucro Líquido / } \\
\text { Patrimônio } \\
\text { Líquido }\end{array}$ & $(+)$ & Al-Najjar (2013) \\
\hline $\begin{array}{l}\text { Retorno sobre } \\
\text { o Ativo }\end{array}$ & ROA & $\begin{array}{l}\text { Lucro Líquido / } \\
\text { Ativo Total }\end{array}$ & $(+)$ & $\begin{array}{c}\text { Luo (2011), Chen et al. (2012) e Kirch, Procianoy e } \\
\text { Terra (2014) }\end{array}$ \\
\hline
\end{tabular}




\begin{tabular}{|c|c|c|c|c|}
\hline $\begin{array}{l}\text { Variáveis } \\
\text { Explicativas }\end{array}$ & Sigla & $\begin{array}{c}\text { Definição } \\
\text { Operacional }\end{array}$ & $\begin{array}{l}\text { Resultado } \\
\text { Esperado }\end{array}$ & Autores \\
\hline Liquidez & $\mathrm{LC}$ & $\begin{array}{l}\text { Ativo } \\
\text { Circulante / } \\
\text { Passivo } \\
\text { Circulante }\end{array}$ & $(-)$ & $\begin{array}{l}\text { Ferreira e Vilela (2004), Ozkan e Ozkan (2004), Al- } \\
\text { Najjar (2013) e Dahroug e Saito (2013). }\end{array}$ \\
\hline $\begin{array}{l}\text { Capital } \\
\text { Circulante } \\
\text { Líquido }\end{array}$ & CCL & $\begin{array}{l}\text { Ativo } \\
\text { Circulante - } \\
\text { Passivo } \\
\text { Circulante } \\
\end{array}$ & $(-)$ & $\begin{array}{l}\text { Opler et al. (1999), Almeida, Campello e Weisbach } \\
\text { (2004), Bates, Kahle e Stulz (2009) e Sun e Wang } \\
\text { (2015). }\end{array}$ \\
\hline $\begin{array}{l}\text { Dívidas de } \\
\text { Curto Prazo }\end{array}$ & DCP & $\begin{array}{l}\text { Passivo } \\
\text { Circulante / } \\
\text { Ativo Total } \\
\end{array}$ & $(-)$ & Almeida, Campello e Weisbach (2004) \\
\hline Dummy Crise & Crise & $\begin{array}{l}\text { Variável } \\
\text { Dummy (Anos } \\
\text { de } 2008 \text { e } 2009 \\
=1 ; \text { Restante = } \\
0 \text { ) }\end{array}$ & $(+)$ & $\begin{array}{l}\text { Dahroug e Saito (2013), Sun e Wang (2015) e Tortoli } \\
\text { e Moraes (2016). }\end{array}$ \\
\hline Dummy Setor & Setor & $\begin{array}{l}\text { Variável } \\
\text { Dummy } \\
\text { (Empresa do } \\
\text { Mesmo Setor = } \\
1 ; \text { Setor } \\
\text { Diferente }=0 \text { ) }\end{array}$ & N/A & $\begin{array}{l}\text { Guney, Ozkan e Ozkan (2007), Gao, Harford e Li } \\
\text { (2013) e Chung et al. (2015). }\end{array}$ \\
\hline Dummy IFRS & IFRS & $\begin{array}{l}\text { Variável } \\
\text { Dummy }(\text { A } \\
\text { partir de } 2010 \\
=1 ; \text { Antes }=0)\end{array}$ & $(-)$ & N/A \\
\hline
\end{tabular}

Fonte: Elaboração Própria

Optou-se nesse trabalho pela utilização de regressão com dados em painel, por meio de um painel desbalanceado. Segundo Fávero (2015) os modelos de regressão em painel são muito úteis quando da necessidade de estudar um fenômeno que, por sua vez, pode se alterar conforme o decorrer dos anos e do indivíduo analisado. Além disso, a utilização de dados em painel na literatura de contabilidade e finanças vem aumentando ao longo do tempo (FÁ VERO, 2013).

O diferencial dos modelos de regressão para dados em painel consiste na análise de um montante mais elevado de informações, assim como em um maior número de graus de liberdade e eficiência da estimação dos parâmetros. Ademais, tais modelos ainda permitem uma maior variabilidade dos dados, que por sua vez, também pode contribuir na redução da multicolinearidade possivelmente existente entre as variáveis e proxies utilizadas (FÁVERO, 2015). 


\section{RESULTADOS}

Neste tópico são apresentados e discutidos os resultados obtidos neste trabalho. A análise baseou-se em uma amostra com 141 organizações de capital aberto, exceto financeiras, contemplando um total de 1906 observações por meio de um painel desbalanceado ao longo do período entre 2000 e 2014.

Em um primeiro momento são apresentados a variação dos níveis de caixa ao longo do período, as estatísticas descritivas e os pressupostos da regressão utilizada. Posteriormente, os resultados obtidos por meio do modelo de Efeitos Fixo com o uso da técnica de regressão robusta, e por fim, as análises por meio da utilização de tal modelo.

Tabela 3. Variação dos Níveis de Caixa

\begin{tabular}{c|c|c|c|c|c|c|c|c|c|c|c|c|c|c|c}
\hline Ano & 00 & 01 & 02 & 03 & 04 & 05 & 06 & 07 & 08 & 09 & 10 & 11 & 12 & 13 & 14 \\
\hline Média (\%) & 7,66 & 7,35 & 7,54 & 6,94 & 7,31 & 8,45 & 9,11 & 10,42 & 10,74 & 12,09 & 7,78 & 8,46 & 8,47 & 8,76 & 7,93 \\
\hline Observações & 122 & 123 & 118 & 127 & 132 & 130 & 132 & 130 & 129 & 131 & 122 & 126 & 128 & 127 & 129 \\
\hline
\end{tabular}

Fonte: Elaboração Própria

A média anual dos níveis de caixa em função do Ativo Total pode ser observado conforme Tabela 3. Por meio dessa tabela, verifica-se um aumento do saldo de caixa a partir do ano 2001 até os anos de 2008 e 2009, o que demonstra o impacto da crise do subprime americana na variável dependente. Posteriormente ao ano de 2010, observa-se uma redução dos níveis de caixa em relação a 2009, de 35,65\%. Tal redução, pode ser em função da adoção obrigatória das IFRS, que passou a ser obrigatoriamente requerida na elaboração das demonstrações financeiras no ano de 2010.

Por fim, a média geral do nível de caixa das 141 organizações ao longo dos 15 anos foi de 8,62\%, valor este menor inclusive do que o obtido por Gao, Harford e Li (2013), que encontraram um valor médio de 9,39\% para as organizações de capital aberto e $17,17 \%$ para aquelas de capital fechado. Além do mais, o valor médio aqui obtido foi próximo ao encontrado por Han e Qiu (2007), 8,4\%, e de Almeida, Campello e Weisbach (2004), que observou uma média em seu trabalho de caixa e de seus equivalentes em torno de $8-9 \%$ para aquelas sem restrição de crédito e $15 \%$ para as com restrições.

Do mesmo modo, o valor médio aqui obtido também foi inferior ao encontrado por Bates et al. (2009) para o ano de 2006, que representou em torno de $23 \%$ do total dos ativos das companhias EUA, tal como menor ao encontrado por Opler et al. (1999) de 18\% do Ativo Total no ano de 1994. Entretanto, a média do caixa e seus equivalentes 
aqui encontrada foi inferior ao obtido por Dahroug e Saito (2013), que a partir de sua amostra (2001-2011) com empresas brasileiras obteve um valor médio de 6,5\%.

Logo, os resultados aqui encontrados vêm ao encontro do sinalizado Dittmar, Mahrt-Smith e Servaes (2003) em seu estudo, uma vez que, espera-se que as empresas situadas em países com um mercado de capitais menos desenvolvidos mantêm saldos de caixa mais elevados do que aquelas oriundas de mercados desenvolvidos.

Ao dividir a amostra utilizada pelos critérios de Restrição Financeira e Governança Corporativa no intuito de verificar a variação dos Níveis de Caixa (Caixa e Equivalentes / Ativo Total), observou-se, conforme Tabela 4, que as organizações que distribuíram pelo menos $1 \%$ do seu Lucro Líquido, 34,58\% da amostra, reservaram uma parte maior do total de seus ativos em Caixas e Equivalentes (11,83\%), quando comparados ao restante que distribuiu menos de $1 \%$ de seu lucro, que apresentaram um nível médio de $6,93 \%$, em que $64,80 \%$ sequer distribuiu dividendos.

Em relação ao Tamanho e a Idade das empresas, observou-se que aquelas classificadas no grupo como sendo Restritas mantiveram um percentual maior dos seus ativos em caixa do que aquelas do grupo Irrestrito. Tais resultados, inicialmente, podem indicar que as organizações restritas mantêm maiores reservas por razões precaucionarias.

Tabela 4. Média dos Níveis de Caixa das proxies de Restrição Financeira e Governança Corporativa

\begin{tabular}{|c|c|c|c|}
\hline Variável & Medida & Níveis de Caixa & Observações \\
\hline \multirow{4}{*}{ Dividendos (Restrito) } & Média & $11,83 \%$ & \multirow{4}{*}{659} \\
\hline & Desvio padrão & 0,128346377 & \\
\hline & Mínimo & $0,00 \%$ & \\
\hline & Máximo & $88,57 \%$ & \\
\hline \multirow{4}{*}{$\begin{array}{l}\text { Dividendos } \\
\text { (Irrestrito) }\end{array}$} & Média & $6,93 \%$ & \multirow{4}{*}{1247} \\
\hline & Desvio padrão & 0,097688248 & \\
\hline & Mínimo & $0,00 \%$ & \\
\hline & Máximo & $92,48 \%$ & \\
\hline \multirow{4}{*}{ Restrita (Tamanho) } & Média & $9,21 \%$ & \multirow{4}{*}{477} \\
\hline & Desvio padrão & 0,151172137 & \\
\hline & Mínimo & $0,00 \%$ & \\
\hline & Máximo & $92,48 \%$ & \\
\hline \multirow{4}{*}{ Irrestrita (Tamanho) } & Média & $\mathbf{8 , 5 5 \%}$ & \multirow{4}{*}{477} \\
\hline & Desvio padrão & 0,078771196 & \\
\hline & Mínimo & $0,00 \%$ & \\
\hline & Máximo & $44,63 \%$ & \\
\hline Restrita (Idade) & Média & $8,63 \%$ & 483 \\
\hline
\end{tabular}




\begin{tabular}{|c|c|c|c|}
\hline Variável & Medida & Níveis de Caixa & Observações \\
\hline & Desvio padrão & 0,124583421 & \\
\hline & Mínimo & $0,00 \%$ & \\
\hline & Máximo & $92,48 \%$ & \\
\hline \multirow{4}{*}{ Irrestrita (Idade) } & Média & $\mathbf{7 , 7 6 \%}$ & \multirow{4}{*}{486} \\
\hline & Desvio padrão & 0,084901508 & \\
\hline & Mínimo & $0,01 \%$ & \\
\hline & Máximo & $42,58 \%$ & \\
\hline \multirow{4}{*}{ N1 } & Média & $11,06 \%$ & \multirow{4}{*}{234} \\
\hline & Desvio padrão & 0,089290858 & \\
\hline & Mínimo & $0,00 \%$ & \\
\hline & Máximo & $45,86 \%$ & \\
\hline \multirow{4}{*}{$\mathrm{N} 2$} & Média & $10,34 \%$ & \multirow{4}{*}{42} \\
\hline & Desvio padrão & 0,088382618 & \\
\hline & Mínimo & $1,04 \%$ & \\
\hline & Máximo & $27,79 \%$ & \\
\hline \multirow{4}{*}{ NM } & Média & $10,68 \%$ & \multirow{4}{*}{151} \\
\hline & Desvio padrão & 0,082146327 & \\
\hline & Mínimo & $0,21 \%$ & \\
\hline & Máximo & $44,63 \%$ & \\
\hline \multirow{4}{*}{ ADR } & Média & $9,00 \%$ & \multirow{4}{*}{210} \\
\hline & Desvio padrão & 0,071422563 & \\
\hline & Mínimo & $0,00 \%$ & \\
\hline & Máximo & $32,89 \%$ & \\
\hline \multirow{4}{*}{ BIG4 } & Média & $9,37 \%$ & \multirow{4}{*}{1116} \\
\hline & Desvio padrão & 0,1007434 & \\
\hline & Mínimo & $0,00 \%$ & \\
\hline & Máximo & $72,57 \%$ & \\
\hline
\end{tabular}

Fonte: Elaboração Própria

Em se tratando das proxies de Governança Corporativa utilizadas, constata-se que as empresas emissoras de ADR, em qualquer nível, e aquelas auditadas por BIG 4 mantiveram um nível médio de caixas e equivalentes menor quando comparadas as organizações pertencentes as listagens especiais da BM\&FBovespa. De modo que, dentre os três níveis, as organizações listadas no Nível 2 (N2) foram as que apresentaram um menor nível $(10,34 \%)$.

Tabela 5. Média dos Níveis de Caixa por Setor

\begin{tabular}{l|l|r|c}
\hline Variável & \multicolumn{1}{|c|}{ Medida } & Níveis de Caixa & Observações \\
\hline \multirow{4}{*}{ Indústria } & Média & $\mathbf{8 , 6 0 \%}$ & \\
\cline { 2 - 3 } & Desvio padrão & 0,099830816 & \multirow{2}{*}{1187} \\
\cline { 2 - 3 } & Mínimo & $0,00 \%$ & \\
\hline
\end{tabular}




\begin{tabular}{|c|c|c|c|}
\hline Variável & Medida & Níveis de Caixa & Observações \\
\hline & Máximo & $66,79 \%$ & \\
\hline \multirow{4}{*}{ Serviço } & Média & $\mathbf{9 , 9 4 \%}$ & \multirow{4}{*}{221} \\
\hline & Desvio padrão & 0,133809021 & \\
\hline & Mínimo & $0,10 \%$ & \\
\hline & Máximo & $76,93 \%$ & \\
\hline \multirow{4}{*}{ Comércio } & Média & $\mathbf{8 , 0 8 \%}$ & \multirow{4}{*}{498} \\
\hline & Desvio padrão & 0,126501964 & \\
\hline & Mínimo & $0,00 \%$ & \\
\hline & Máximo & $92,48 \%$ & \\
\hline
\end{tabular}

Fonte: Elaboração Própria

Conforme Tabela 5, observa-se que dentre a classificação realizada em três setores, o setor de Serviços foi aquele que apresentou maior nível médio de Caixa e Equivalentes em relação ao Ativo Total. Por outro lado, o que apresentou um menor nível foi o setor de Comércio com média de 8,08\%. O setor de Indústrias, com o maior número de observações (1187) dentro da amostra utilizada, apresentou uma média de 8,60\%.

Em sequência, a Tabela 6 relata a estatística descritiva de todas as variáveis utilizadas no trabalho.

Tabela 6. Estatística Descritiva

\begin{tabular}{|c|c|c|c|c|c|c|c|}
\hline Variável & Média & Mínimo & Máximo & Mediana & Desvio padrão & Curtose & Assimetria \\
\hline Dividendos & 0,376 & $-6,417$ & 81,377 & 0,000 & 2,866 & 511,765 & 20,880 \\
\hline Restrita (Tamanho) & 0,250 & 0,000 & 1,000 & 0,000 & 0,433 & $-0,669$ & 1,154 \\
\hline Irrestrita (Tamanho) & 0,250 & 0,000 & 1,000 & 0,000 & 0,433 & $-0,669$ & 1,154 \\
\hline Restrita (Idade) & 0,253 & 0,000 & 1,000 & 0,000 & 0,435 & $-0,713$ & 1,135 \\
\hline Irrestrita (Idade) & 0,255 & 0,000 & 1,000 & 0,000 & 0,436 & $-0,735$ & 1,125 \\
\hline Dummy Nível 1 & 0,123 & 0,000 & 1,000 & 0,000 & 0,328 & 3,297 & 2,301 \\
\hline Dummy Nível 2 & 0,021 & 0,000 & 1,000 & 0,000 & 0,143 & 42,787 & 6,689 \\
\hline $\begin{array}{l}\text { Dummy Novo } \\
\text { Mercado }\end{array}$ & 0,079 & 0,000 & 1,000 & 0,000 & 0,270 & 7,732 & 3,118 \\
\hline Dummy ADR & 0,110 & 0,000 & 1,000 & 0,000 & 0,313 & 4,214 & 2,492 \\
\hline Dummy Big 4 & 0,586 & 0,000 & 1,000 & 1,000 & 0,493 & $-1,881$ & $-0,347$ \\
\hline Tamanho & 14,351 & 7,208 & 20,629 & 14,253 & 2,072 & $-0,121$ & 0,077 \\
\hline Idade & 3,802 & 0,000 & 5,170 & 3,989 & 0,838 & 1,338 & $-1,229$ \\
\hline $\begin{array}{l}\text { Alavancagem } \\
\text { Financeira } \\
\end{array}$ & 1,335 & $-85,815$ & 111,725 & 1,563 & 10,411 & 35,172 & 0,597 \\
\hline Endividamento & 0,413 & 0,000 & 0,951 & 0,447 & 0,248 & $-1,024$ & $-0,205$ \\
\hline Geração de Caixa & 33,562 & $-70,686$ & 301,571 & 30,171 & 26,428 & 10,849 & 2,198 \\
\hline $\begin{array}{l}\text { Oportunidades de } \\
\text { Investimento }\end{array}$ & 0,131 & $-23,927$ & 13,286 & 0,093 & 0,781 & 524,913 & $-11,904$ \\
\hline ROE & 0,107 & $-18,744$ & 7,533 & 0,107 & 0,733 & 249,662 & $-8,073$ \\
\hline $\mathrm{ROA}$ & 0,015 & $-3,274$ & 2,099 & 0,033 & 0,208 & 95,151 & $-6,020$ \\
\hline $\mathrm{LC}$ & 2,558 & 0,000 & 1117,000 & 1,336 & 26,045 & 1763,164 & 41,325 \\
\hline $\mathrm{CCL}$ & 1099825,582 & $-7154930,573$ & 71922996,766 & 100823,556 & 4952126,929 & 89,865 & 8,341 \\
\hline
\end{tabular}




\begin{tabular}{l|c|c|c|c|c|c|c}
$\begin{array}{l}\text { Dívidas de Curto } \\
\text { Prazo }\end{array}$ & 0,333 & 0,001 & 24,315 & 0,270 & 0,607 & 1279,246 & 32,655 \\
\hline Dummy Crise & 0,136 & 0,000 & 1,000 & 0,000 & 0,343 & 2,498 & 2,120 \\
\hline Dummy IFRS & 0,332 & 0,000 & 1,000 & 0,000 & 0,471 & $-1,489$ & 0,716 \\
\hline Dummy Indústria & 0,623 & 0,000 & 1,000 & 1,000 & 0,485 & $-1,745$ & $-0,507$ \\
\hline Dummy Serviço & 0,116 & 0,000 & 1,000 & 0,000 & 0,320 & 3,769 & 2,401 \\
\hline Dummy Comércio & 0,261 & 0,000 & 1,000 & 0,000 & 0,439 & $-0,818$ & 1,088 \\
\hline
\end{tabular}

Fonte: Elaboração Própria

A fim de atender a questão de pesquisa deste trabalho, realizaram-se os testes de pressupostos e especificação do modelo de regressão de Mínimos Quadrados Ordinários (MQO). Inicialmente foi verificada a normalidade das variáveis que compõem o modelo por meio do teste de Shapiro-Wilk, em apêndice, em que se constata que as variáveis não apresentam distribuição normal, o que pode ocorrer em função da não utilização de uma amostra aleatória e é um comportamento comum em dados financeiros. Na sequência foram realizados testes para verificar se o modelo apresenta especificação adequada, de modo que, os resultados obtidos estão elencados nas Tabelas 7 e 8.

Tabela 7. Pressupostos da Regressão

\begin{tabular}{c|c}
\hline Teste da normalidade dos resíduos & Teste de White para a heterocedasticidade \\
\hline Hipótese nula: o erro tem distribuição Normal & Hipótese nula: sem heterocedasticidade \\
\hline Estatística de teste: Qui-quadrado $(2)=507,509$ & Estatística de teste: $\mathrm{LM}=1285,96$ \\
com p-valor $=6,24887 \mathrm{e}-111$ & com p-valor $=\mathrm{P}($ Qui-quadrado $(323)>1285,96)=$ \\
$6,62867 \mathrm{e}-115$
\end{tabular}

A Tabela 7 demonstra os resultados obtidos via teste de normalidade dos resíduos no qual os resíduos não apresentam distribuição normal. Foi empregado o teste de White, de maneira a testar a heterocedasticidade do modelo, em que se rejeita a hipótese nula, ao verificar que o modelo apresentou problema de heterocedasticidade. Logo, no intuito de analisar de maneira mais adequada o modelo proposto, fez-se uso da técnica de regressão com erros-padrão robusto, uma vez que ela apresenta tratamento adequado em situações em que há problemas de heterocedasticidade.

Tabela 8. Teste Fator de Inflacionamento da Variância (VIF)

\begin{tabular}{l|c}
\hline Variáveis & VIF \\
\hline Dividendos & 1,039 \\
\hline Restrita (Tamanho) & 3,233 \\
\hline Irrestrita (Tamanho) & 3,212 \\
\hline Restrita (Idade) & 3,845 \\
\hline
\end{tabular}




\begin{tabular}{l|c}
\hline Variáveis & VIF \\
\hline Irrestrita (Idade) & 1,903 \\
\hline Dummy Nível 1 & 1,391 \\
\hline Dummy Nível 2 & 1,083 \\
\hline Dummy Novo Mercado & 1,302 \\
\hline Dummy ADR & 1,890 \\
\hline Dummy Big 4 & 1,575 \\
\hline Tamanho & 8,116 \\
\hline Idade & 5,322 \\
\hline Alavancagem Financeira & 1,032 \\
\hline Endividamento & 1,389 \\
\hline Geração de Caixa & 1,083 \\
\hline Oportunidades de Investimento & 5,214 \\
\hline ROE & 1,024 \\
\hline ROA & 1,298 \\
\hline LC & 1,833 \\
\hline CCL & 1,513 \\
\hline Dívidas de Curto Prazo & 4,050 \\
\hline Dummy Crise & 1,120 \\
\hline Dummy IFRS & 1,207 \\
\hline Dummy Indústria & 1,593 \\
\hline Dummy Serviços & 1,459 \\
\hline &
\end{tabular}

Fonte: Elaboração própria.

Nota: Valores acima de 10 indicam potenciais problemas de multicolinearidade.

Em um primeiro, ao analisar os resultados da Tabela 8 por meio do Teste de Fator de Inflacionamento da Variância (Variance Inflation Factor - VIF), o próprio software Gretl ${ }^{\circledR}$ excluiu a Dummy Comércio por colinearidade, uma vez que a mesma compõe com as demais dummies de setor o total de empresas. Destaca-se que nenhum valor do VIF ficou acima de 10, o que poderia indicar problemas relacionados a multicolinearidade. $\mathrm{O}$ maior coeficiente do Teste Fatores de VIF foi o obtido pela variável Tamanho $(8,116)$, o que pode suceder em função do uso dessa variável também como critério de restrição financeira, por meio dos quartis.

Posteriormente ao teste VIF também foram realizados os testes de Breusch-Pagan e Hausman, conforme Tabela 9, no intuito de verificar dentre os modelos de Efeitos Fixos, Efeitos Aleatórios e Mínimos Quadrados Ordinários (MQO), aquele que melhor se adequa aos dados contemplados neste estudo. 
Tabela 9. Testes para escolha do modelo de Dados em Painel

\begin{tabular}{c|c|c}
\hline $\begin{array}{c}\text { Teste robusto para diferenciar } \\
\text { interceptos de grupos: }\end{array}$ & Teste de Breusch-Pagan & Teste de Hausman \\
\hline H0: modelo MQO & H0: modelo MQO & H0: modelo de efeitos aleatórios \\
H1: modelo de efeitos fixos
\end{tabular}

Fonte: Elaboração própria.

Analisando os testes supracitados, percebe-se que o modelo de Efeitos Fixos é o que melhor se ajusta para o modelo de regressão com dados em painel aqui proposto. Posto isso, a análise deste trabalho utilizou o modelo de Efeitos Fixo com o uso da técnica de regressão com erros-padrão robusto, vide Tabela 10. Além do mais, os efeitos fixos se justificam pela análise dos efeitos em cada empresa, uma vez que a decisão de caixa é da própria empresa e existe uma expectativa que ocorra a manutenção desse caixa ao longo do tempo, obtendo um melhor tratamento no modelo de Efeitos Fixos.

Também foi aplicado o teste de Durbin-Watson, sendo o resultado obtido de 1,146 (Tabela 10), podendo indicar problemas de autocorrelação serial positiva, porém, há de se ponderar que existem elementos estocásticos no modelo e que o mesmo é estático com dados em painel, o que pode prejudicar esta análise.

Tabela 10. Modelo de Regressão de Efeitos Fixos com Erros-Padrão Robusto

\begin{tabular}{l|c|c|c|c}
\hline \multicolumn{1}{c|}{ Variáveis } & Coeficientes & Erro Padrão & Razão- $\boldsymbol{p}$ & -valor \\
\hline Constante & $-8,5481$ & 2,2726 & $-3,7610$ & $0,0002 * * *$ \\
\hline Dividendos & $\mathbf{- 0 , 0 1 0 4 9}$ & $\mathbf{0 , 0 0 5 6}$ & $\mathbf{- 1 , 8 5 3 0}$ & $\mathbf{0 , 0 6 5 9} *$ \\
\hline Restrita (Tamanho) & 0,5461 & 0,3989 & 1,3690 & 0,1732 \\
\hline Irrestrita (Tamanho) & $\mathbf{- 0 , 4 6 5 4}$ & $\mathbf{0 , 2 5 4 7}$ & $\mathbf{- 1 , 8 2 7 0}$ & $\mathbf{0 , 0 6 9 8} *$ \\
\hline Restrita (Idade) & $-0,2697$ & 0,2614 & $-1,0320$ & 0,3038 \\
\hline Irrestrita (Idade) & $\mathbf{- 0 , 6 4 5 5}$ & $\mathbf{0 , 2 2 2 9}$ & $\mathbf{- 2 , 8 9 6 0}$ & $\mathbf{0 , 0 0 4 4} * * *$ \\
\hline Dummy Nível 1 & 0,0876 & 0,2182 & 0,4015 & 0,6886 \\
\hline Dummy Nível 2 & $\mathbf{0 , 7 2 4 9}$ & $\mathbf{0 , 1 9 9 3}$ & $\mathbf{3 , 6 3 7 0}$ & $\mathbf{0 , 0 0 0 4} * * *$ \\
\hline Dummy Novo Mercado & 0,2075 & 0,2900 & 0,7156 & 0,4754 \\
\hline Dummy ADR & 0,6752 & 0,4396 & 1,5236 & 0,1268 \\
\hline Dummy Big 4 & 0,1459 & 0,1257 & 1,1600 & 0,2479 \\
\hline Tamanho & 0,2050 & 0,1526 & 1,3430 & 0,1814 \\
\hline Idade & 0,2783 & 0,2373 & 1,1730 & 0,2427 \\
\hline Alavancagem Financeira & 0,0035 & 0,0026 & 1,3370 & 0,1833 \\
\hline Endividamento & $\mathbf{1 , 1 7 4 8}$ & $\mathbf{0 , 3 6 4 1}$ & $\mathbf{3 , 2 2 6 0}$ & $\mathbf{0 , 0 0 1 6} * * *$ \\
\hline Geração de Caixa & 0,0000 & 0,0019 & 0,5098 & 0,6110 \\
\hline Oportunidades de & $\mathbf{1 , 6 5 0 7}$ & $\mathbf{0 , 6 4 5 1}$ & $\mathbf{2 , 5 5 9 0}$ & $\mathbf{0 , 0 1 1 6} * *$ \\
\hline Investimento & 0,0279 & 0,0364 & 0,7665 & 0,44447 \\
\hline ROE & 0,4341 & 0,2911 & 1,4910 & 0,1381 \\
\hline ROA & $\mathbf{- 0 , 0 1 2 3}$ & $\mathbf{0 , 0 0 6 5}$ & $\mathbf{- 1 , 8 7 4 0}$ & $\mathbf{0 , 0 6 3 0} *$ \\
\hline LC & 0,00000 & 0,0000 & 1,3890 & 0,1672 \\
\hline CCL & $\mathbf{1 , 6 4 4 1}$ & $\mathbf{0 , 6 4 2 1}$ & $\mathbf{2 , 5 6 0 0}$ & $\mathbf{0 , 0 1 1 5} * *$ \\
\hline Dívidas de Curto Prazo & & &
\end{tabular}




\begin{tabular}{l|c|c|c|c} 
Dummy Crise & $\mathbf{0 , 2 8 4 4}$ & $\mathbf{0 , 1 0 9 9}$ & $\mathbf{2 , 5 8 8 0}$ & $\mathbf{0 , 0 1 0 7} * *$ \\
\hline Dummy IFRS & $-\mathbf{0 , 3 9 1 4}$ & $\mathbf{0 , 1 6 8 5}$ & $\mathbf{- 2 , 3 2 2 0}$ & $\mathbf{0 , 0 2 1 7} * *$ \\
\hline $\mathbf{R}^{2}=\mathbf{0 , 2 2 5 5 7 1}$ & & $\mathbf{F}(\mathbf{2 3 , 1 4 0})=$ & P-valor $(\boldsymbol{F}) 1,59356 \mathrm{e}-$ & \\
\hline Observações $(\boldsymbol{n})$ & $\mathbf{2 2 , 8 4 8 8}$ & $\mathbf{0 3 6}$ & \\
\hline Teste de Durbin-Watson & $\mathbf{1 , 1 4 6 0}$ & & & \\
\hline
\end{tabular}

Fonte: Elaboração própria.

Notas: * estatisticamente significativo a 10\%; ** estatisticamente significativo a 5\%; *** estatisticamente significativo a $1 \%$.

Posto isso, o próximo tópico, discorre sobre as análises das variáveis utilizadas e dos resultados obtidos no modelo proposto. 


\section{ANÁLISE DOS RESULTADOS}

Analisando os resultados obtidos pela regressão com efeitos fixos, verifica-se que dentre os critérios de restrição financeira utilizados os fatores Dividendos, Tamanho e Idade para as organizações consideradas como irrestritas financeiramente apresentaram significância estatística, ao nível de 10\%,10\% e 1\% respectivamente, inclusive com os sinais negativos já esperados. Dessa forma, os resultados sugerem que as companhias que pagam um maior percentual do seu lucro, assim como as maiores e mais velhas mantêm menores níveis de caixa.

As grandes empresas, como esperado, têm melhor acesso ao mercado de capitais, assim como podem sofrer menos aos problemas relacionados a assimetria informacional. As empresas de menor tamanho, por sua vez, geralmente são menos conhecidas e são passiveis de maior vulnerabilidade das imperfeições do mercado de capitais.

Em se tratando especialmente da idade, isso pode suceder em função das organizações mais velhas serem mais conhecidas e estabelecidas no mercado, o que para Lyandres (2007) ocorre devido as companhias mais antigas possuírem um menor grau de assimetria informacional e, por consequente, custos de captação de recursos mais baixos do que as organizações mais jovens, o que as possibilita manter níveis de caixa menores.

Logo, não se rejeita a segunda hipótese de pesquisa para as variáveis Irrestrita (Tamanho) e Irrestrita (Idade), verificando-se que as organizações sem restrições financeiras mantêm menores níveis de caixa do que as classificadas como restritas.

A variável pagamento de dividendos, assim como previsto pelos pressupostos teóricos, apresentou uma associação negativa com os níveis de caixa, apesar de significância ao nível de $10 \%$. Observando também a Tabela 4, verifica-se que as companhias que distribuíram ao menos $1 \%$ do seu lucro (659 observações) apresentaram percentual maior do total de seus ativos em Caixas e Equivalentes $(11,83 \%)$, em relação ao grupo que distribuiu menos de $1 \%$ do lucro $(6,93 \%)$ ou nada.

Logo, evidencia-se que o grupo que distribuiu pelo menos $1 \%$ do seu lucro $(34,58 \%)$ mantêm níveis maiores em caixa do que aqueles que distribuem menos de $1 \%$. Esse resultado pode indicar que as empresas brasileiras são mais conservadoras e que, além das questões que regulam tal comportamento, elas podem distribuir um percentual maior de dividendos quando estão com maiores reservas de caixa. 
Sendo assim, as empresas classificadas como restritas mantiveram maiores reservas de caixa, assim como observado por Almeida, Campello e Weisbach (2004) e Faulkender e Wang (2006) em seus trabalhos. A justificativa para este fato se dá em função de que as empresas restritas são mais dependentes dos recursos gerados internamente e, portanto, precisam se resguardar mais. Por outro lado, as irrestritas, mantem níveis menores, uma vez que podem acessar a fontes externas quando de sua necessidade (FAULKENDER; WANG, 2006).

Além disso, ao considerar como um todo, a variável dividendos resultou em uma associação negativa a variável dependente, denotando que as empresas que distribuem um menor percentual de seus lucros mantêm maiores reservas de caixa. Tal resultado vem ao encontro daqueles obtidos por Fazzari, Hubbard e Petersen (1988), Gilchrist e Himmelberg (1995), Opler et al. (1999) e Bates, Kahle e Stulz (2009), no qual há evidências de que o aumento nos níveis de caixa predomina nas organizações que não distribuem dividendos.

A opção pela inclusão das variáveis Tamanho e Idade, além da inclusão das dummies de restrição financeira ( $1^{\circ}$ quartil e $4^{\circ}$ quartil), ocorreu também no sentido de analisar os seus efeitos sobre o caixa. O resultado da regressão para estas duas variáveis (Tamanho e Idade), apesar de positivo, como esperado, não foi significativo. O resultado positivo, apesar da não significância, sugere, segundo Ozkan e Ozkan (2004), que outros fatores também possam influenciar a maneira pela qual o tamanho da empresa exerce influência sobre as suas decisões de retenção de caixa.

Sendo assim, Ozkan e Ozkan (2004) indicam, por exemplo, que as empresas grandes podem ser mais bem-sucedidas na geração de fluxo de caixa e lucros para que elas possam acumular mais dinheiro e títulos negociáveis. Ademais, pode ser uma opção da empresa manter níveis mais elevados de caixa.

Dentre as variáveis de Governança Corporativa, somente a Dummy Nível 2 obteve significância estatística a um nível de 1\%. E diferentemente ao esperado, o resultado foi contrário, demonstrando que as organizações participantes na listagem especial Nível 2 da BM\&FBovespa de diferenciação mantêm níveis maiores de caixa. As demais dummies deste eixo (Nível 1, Novo Mercado, ADR e Big 4), apesar da não obtenção de significância estatística, também estão associadas positivamente com os níveis de caixa, o que rejeita a terceira hipótese deste trabalho de que as organizações com melhores níveis de Governança Corporativa mantêm menores níveis de caixa. 
Ademais, menciona-se o número pequeno de empresas listadas no Nível 2, uma vez que, apenas 42 observações/ano estiveram neste nível especial, conforme Tabela 4. E, mesmo que significante, as empresas emissoras de $\operatorname{ADR}(9,00 \%)$, em qualquer nível, e aquelas auditadas por BIG $4(9,37 \%)$ mantiveram um nível médio de caixa menor do que as pertencentes no Nível 2 (10,34\%) da BM\&FBovespa.

O sinal positivo das variáveis de governança vem de acordo aos resultados obtidos por Tortoli e Moraes (2016) em sua variável de Governança Corporativa. Os autores utilizaram uma dummy atribuindo o valor 1 caso a empresa esteja listada em um dos três níveis especial da BM\&FBovespa (Nível 1, Nível 2 e Novo Mercado) e 0 caso contrário.

O resultado obtido por Tortoli e Moraes (2016) para a sua variável de governança, também foi contrário ao esperado pela literatura. Logo, uma possível redução dos conflitos de agência e os consequentes custos de agência a partir de adoção, por exemplo, dos níveis diferenciados da BM\&FBovespa (Nível 1, Nível 2 e Novo Mercado), emissão de ADR e auditorias externas por meio de BIG 4 não se mostrou significante na redução dos níveis de caixa das organizações.

Entretanto, a associação positiva aqui obtida para as variáveis de governança também foi encontrada por Harford, Mansi e Maxwell (2008) em seu estudo com empresas americanas. Os autores interpretam esse resultado dizendo que a manutenção de maiores reservas de caixa pelas empresas com melhores práticas de governança pode decorrer do fato de que os mecanismos de governança possibilitam as empresas disponibilizar para os gestores níveis de caixa mais elevados, sem que estes expropriem o montante a mais de maneira a maximizar a sua função utilidade às custas do principal.

E esse resultado também pode ser interpretado de modo semelhante ao obtido por Kalcheva e Lins (2007), uma vez que os pesquisadores demonstraram em seu trabalho que os investidores externos descontam o valor de firmas que possam sofrer com maiores conflitos de agência, assim como quando da manutenção de saldos maiores de caixa na ausência de fortes mecanismos de proteção dos interesses dos acionistas, dado a maior possibilidade de expropriação do capital por parte dos gestores.

Em outras palavras, a obtenção de uma associação positiva entre as proxies de governança corporativa pode sinalizar, por exemplo, que todos os critérios necessários para se enquadrar nas listagens especiais da BM\&FBovespa, assim como na emissão de ADRs e ser auditada por uma Big 4 possibilitam monitorar de forma mais eficaz as ações do agente, de maneira que neste contexto o principal possa disponibilizar ao agente níveis maiores de caixa (HARFORD; MANSI; MAXWELL, 2008). 
E o mesmo raciocínio pode ser aplicado para aquelas empresas com piores práticas de governança. Logo, devido a impossibilidade de controlar todas as ações do agente devido a inexistência de mecanismos robustos de governança, o principal disponibiliza um monte menor de caixas e equivalentes para o agente gerenciar, uma vez que é esperado que em algum momento ele busque maximizar a sua função utilidade. Sendo assim, os resultados sugerem que neste caso, as reservas de caixa menores ocorrem no intuito de mitigar os conflitos de agência relacionados com reservas de caixa em excesso (HARFORD; MANSI; MAXWELL, 2008).

Amess, Banerji e Lampousis (2015) complementam essa visão ao mencionarem que a qualidade da governança corporativa não influencia necessariamente na decisão de acumular caixa, mas sim em relação a decisão de gastar caixa em excesso ou não. Posto isso, a flexibilidade na utilização das reservas de caixa, segundo os autores, só tem valor para os acionistas sob contextos de forte governança corporativa, onde há maiores garantias de que os saldos de caixa serão utilizados em circunstâncias que aumentem o valor do acionista.

Menciona-se também que uma possível alternativa ao uso de proxies relacionadas aos construtos Restrição Financeira e Governança Corporativa seria a criação de um fator para cada uma destas dimensões utilizando a Análise Fatorial. Todavia, o resultado da técnica, representado pelo fator, não apresentou significância estatística nos resultados do teste de KMO (Kaiser-Meyer-Olkin), em apêndice, uma vez que os valores obtidos para tais testes foram 0,515 e 0,483 , respectivamente para as proxies de restrição financeira e governança.

E para Fávero et al. (2009) quanto mais próximo de 1 o valor do teste mais adequado a utilização da fatorial. Sendo assim, como os valores do teste para ambas as variáveis foram inferiores a 0,60, Fávero et al. (2009) sugere que a análise fatorial pode não ser adequada.

Dentre as variáveis de controle, o Endividamento e as Oportunidades de Investimentos apresentaram significância estatística ao nível de $1 \%$ e $5 \%$ respectivamente. O resultado da variável Endividamento vem de encontro a literatura, de modo que, esperava-se uma associação negativa entre tais variáveis, porém, o resultado demonstrou, a partir da amostra utilizada, uma relação positiva. Embora contrário, podese esperar também que as companhias mais endividadas mantenham maiores níveis de caixa como uma possível garantia. 
Por outro lado, as organizações com maiores Oportunidades de Investimento possuem uma demanda mais elevada por caixa, em função do caso da insuficiência de caixa e dos custos mais elevados de captação de recursos, elas poderiam perder valiosas oportunidades de investimento. Desta maneira, o resultado obtido para esta variável está de acordo com o sinalizado pela literatura.

A variável aqui utilizada como proxy para o constructo geração de caixa apresentou um efeito positivo sobre as reservas de caixa, conforme o esperado, porém não significante estatisticamente. Apesar de não ser significante, o resultado positivo vai ao encontro dos pressupostos teóricos da literatura, em que espera-se que as companhias com maiores fluxos de caixa mantenham níveis de caixa mais elevados como resultado de sua preferência por fontes internas em detrimento das externas.

As duas métricas de rentabilidade utilizadas, ROE e ROA não obtiveram significância estatística. Por outro lado, o resultado está de acordo com o previsto pela literatura, no qual espera-se uma associação positiva entre as variáveis de rentabilidade e a variável cash holdings.

A variável de liquidez utilizada, Liquidez Corrente, obteve uma associação negativa com os níveis de caixa, como esperado, apesar de o coeficiente estimado ser significativo ao nível de 10\%. E isso ocorre, pois, as companhias podem utilizar seus ativos líquidos (não caixa) como substitutos das reservas de caixa quando de sua deficiência.

Entretanto, os resultados encontrados para as variáveis Capital Circulante Líquido (CCL) e Dívidas de Curto Prazo foram contrários ao sugerido pela literatura, de modo ainda que apenas a segunda obteve significância ao nível de 5\%. Esperava-se uma associação positiva, haja vista que, ambas as variáveis podem ser substitutas do caixa, porém o resultado sugere uma associação positiva, o que implica que outros fatores estejam afetando estas variáveis.

Esperava-se em um primeiro momento uma associação negativa entre a Alavancagem Financeira (Lev) e as reservas de caixa. Todavia, o resultado encontrado foi positivo e não significativo, contrariando as evidências sugeridas pelos autores, conforme Quadro 1, de que as companhias com coeficientes de endividamento mais elevados mantêm reservas de caixa mais baixas.

A variável dummy crise como esperado, obteve uma associação positiva com os níveis de caixa a um nível de significância de 5\%, o que sugere que as companhias brasileiras mantiveram reservas de caixa maiores durante os anos de 2008 e 2009 em 
função da crise do subprime americana, o que também pode ser observado por meio da Tabela 3 que demonstra as variações dos níveis de caixa durante o período analisado. Esse resultado sugere que a manutenção de reservas de caixa mais elevadas podem ocorrer em função de uma possível redução da disponibilidade de crédito e mesmo quando de sua existência o custo de captação possa ser proibitivo, o que faz com que as organizações se resguardem previamente no intuito de precaver possíveis faltas de recursos.

Por outro lado, Kahle e Stulz (2013) argumentam em seu trabalho que ao invés de um choque de crédito, os efeitos da crise do subprime americana podem ter ocorrido também em função de um choque da demanda. E, para os autores, esse fato sucede dado a uma demanda menor por financiamento por parte das empresas durante períodos de crise.

Por fim, a variável dummy IFRS, apresentou uma associação negativa ao nível de $5 \%$, o que representa uma redução nos níveis mantidos em caixa pelas organizações posteriormente a adoção obrigatória das IFRS. Esse resultado está alinhado com o sinalizado pelos artigos sobre o tema, uma vez que, com a adoção das normas internacionais é esperado que os usuários sejam beneficiados com informações mais comparáveis, transparentes e de maior qualidade, reduzindo, portanto, os problemas relacionados a assimetria de informação e conflitos de agência. 


\section{CONSIDERAÇÕES FINAIS}

O presente trabalho contribuiu para os estudos sobre as políticas de caixa brasileiras de maneira a fornecer evidências acerca dos efeitos das restrições financeiras e governança corporativa, além de considerar os efeitos da crise financeira e da adoção do padrão IFRS sobre os saldos de caixa das organizações brasileiras não financeiras listas na BM\&FBovespa.

O período amostral utilizado inicia-se em 2000 e se estende até 2014 , de forma a analisar um período maior que os demais trabalhos brasileiros, incluindo dentro da amostra todas as organizações com dados disponíveis durante todos os 15 anos. Optouse pela utilização do modelo de regressão com dados em painel, por meio de um painel desbalanceado, de maneira a não reduzir o número de observações utilizadas.

Logo, em função da utilização de 141 empresas ao longo de 15, obteve-se um total de 2215 observações. Porém, após a exclusão de outliers o número final de observações foi de 1906, para as mesmas 141 companhias.

Os resultados obtidos apontaram que as organizações mantêm em média 8,62\% dos seus Ativos Totais em caixas e equivalentes. Além disso, obteve-se evidências que o nível de caixa das organizações é impactado pelo nível de sua restrição financeira, assim como por contextos de crise, onde as companhias elevaram as suas reservas de caixa sob tal cenário.

Em se tratando dos critérios de restrição financeira, os resultados aqui obtidos demonstraram que as organizações sem restrições mantêm menores níveis de caixa do que aquelas classificadas como restritas. Tal resultado indica que a disponibilidade de crédito, como já discutido por outros trabalhos, é um fator trivial no processo de tomada de decisão sobre os investimentos das organizações, em especial, no contexto brasileiro, marcado pelo baixo acesso ao crédito e elevados custos de captação.

Deste modo, a decisão entre manter maiores ou menores reservas de caixa pelas empresas brasileiras também é impactada pelo nível de restrição financeira de cada companhia. Especialmente, em se tratando sobre aspectos do tamanho, idade e pagamento de dividendos, observou-se que as empresas maiores e mais antigas mantêm menores níveis de caixa do que as menores e mais recentes, e aquelas que distribuíram mais dividendos reservaram uma parte maior do total de seus ativos em Caixas e Equivalentes. Sinalizando, deste modo, que as empresas do mercado acionário brasileiro podem ser 
mais conservadoras, e distribuir um maior percentual de seus lucros apenas quando estão com maiores reservas de caixa.

Dentre as variáveis de governança corporativa utilizadas neste trabalho, somente a listagem no Nível 2 da BM\&FBovespa apresentou significância estatística ao nível de 1\%. Todavia, mesmo não significantes, todas apresentaram um sinal positivo contrariando, portanto, os pressupostos teóricos. Além disso, as empresas emissoras de ADR, em qualquer nível, foram aquelas que apresentaram menor nível de caixa.

Dessa forma, a associação positiva entre as variáveis de governança com o nível de caixa sinaliza que as boas práticas de governança possibilitam as empresas disponibilizarem maios reservas de caixa aos gestores, de modo a proteger os saldos mais elevados em função da existência de menores problemas de agência. Do mesmo modo, dado a impossibilidade das empresas sem boas práticas de governança corporativa em controlar as ações oportunistas do agente, os resultados sugeriram que, neste caso, o principal disponibiliza um montante menor de caixas e equivalentes para o agente administrar em decorrência dos maiores conflitos de agência.

Análises mais aprofundadas ainda sugerem que a qualidade da governança corporativa não afeta necessariamente a decisão de acumular caixa. Ao invés disso, sinaliza que os mecanismos de governança conseguem proteger as reservas de caixa, de modo que elas não sejam desperdiçadas em projetos mais arriscados ou até mesmo não rentáveis. Logo, o uso de mecanismos robustos de governança corporativa pode garantir que as reservas de caixa serão utilizadas apenas em situações que maximizem a utilidade do acionista.

Uma outra possível explicação para o resultado obtido de que as empresas com maiores problemas de agência mantem menores níveis de caixa é de que estas empresas distribuem percentuais maiores de seus lucros como dividendos. Logo, aprofundar os estudos nesta área pode ser uma oportunidade para novos estudos, assim como buscar novas proxies na tentativa de capturar melhor o efeito de boas práticas de governança corporativa sobre os níveis de caixa.

Em relação a adoção das IFRS e os seus efeitos sobre os níveis de caixa, observouse que após a adoção obrigatória das normas (2010) na elaboração das demonstrações financeiras houve uma redução significativa nos níveis de caixa, representando uma queda de 35,65\%, em relação ao ano de 2009. Além disso, a dummy IFRS de adoção obrigatória obteve uma associação negativa ao nível de 5\%. Porém, a adoção das normas por si talvez não represente toda essa variação, indicando, por exemplo, que outros 
fatores, como questões relacionadas ao sistema legal e político e os mecanismos de enforcement também influenciem nessa redução.

Apesar das contribuições feitas, este trabalho também possui suas limitações. Essas limitações podem suceder, por exemplo, em função da amostra não aleatória empregada e envolvendo apenas organizações brasileiras, assim como pelos métodos econométricos utilizado e as proxies relacionadas a restrição financeira e governança corporativa.

Além do mais, identificar quais organizações são financeiramente restritas é um tema que vem sendo debatido na literatura econômica e financeira, de modo que ainda não há consenso de proxies robustas que consigam capturar o construto restrição financeira. E os resultados existentes que têm sido atribuídos as fricções financeiras podem na verdade refletir as diferenças nas políticas de investimento e de financiamento de empresas em diferentes fases do seu ciclo de vida.

Posto isso, novos trabalhos também podem aproveitar esta lacuna na intenção de buscar novas proxies para o constructo restrição financeira de maneira a ampliar o entendimento sobre o tema envolvendo o gerenciamento de caixa das organizações brasileiras. Além do mais, ampliar a amostra para outros países também é um caminho natural a ser explorado em novos trabalhos para fins comparativos.

Estudos que, da mesma forma, analisem os níveis de caixa em organizações de capital fechado podem ser de grande interesse, haja vista a baixa quantidade de trabalhos dessa temática envolvendo tal tipo societário. Do mesmo modo, novos estudos também podem abordar as diferenças nos níveis de caixa entre empresas de capital aberto, fechado e em pequenas e médias empresas.

Ademais, uma série de outras variáveis podem influenciar as políticas de caixa de uma organização, o que possibilita estudos com outros fatores que também possam influenciar a gestão do caixa das empresas. Os resultados obtidos neste trabalho, por exemplo, demonstraram uma redução da média dos níveis de caixa mantidos pelas organizações de 35,65\% após a adoção obrigatória brasileira as IFRS em 2010, o que pode ser melhor analisado por novos estudos no Brasil e no Mundo.

A adoção das IFRS, por exemplo, é um dos temas mais relevantes da contabilidade e vem sendo objeto de estudos e debates entre pesquisadores e profissionais da área. Os possíveis benefícios e as consequências da adoção das normas do Brasil, a partir de 2008 com a Lei 11.638/07 e a adoção parcial brasileira e posteriormente em 2010 com a adoção obrigatória são de interesse de grande parte participantes do mercado, haja vista, que os 
impactos afetam diretamente a economia brasileira e mundial. Logo, os efeitos da adoção das IFRS sobre as políticas de caixa das empresas, também representa um potencial tema que pode ser melhor posicionado em trabalhos futuros.

Por fim, a realização de surveys indagando diretamente aos gestores das companhias brasileiras, quais fatores são preponderantes na determinação dos níveis de caixa em cada companhia também podem ser de grande valia, haja vista, a ausência de trabalhos sob esta perspectiva metodológica envolvendo o tema aqui estudado em solos brasileiro. 


\section{REFERÊNCIAS}

AHMED, K.; CHALMERS, K.; KHLIF, H. A Meta-Analysis of IFRS Adoption Effects. International Journal of Accounting, v. 48, n. 2, p. 173-217, 2013.

AKERLOF, G. A. The Market for lemons: qualitative uncertainty and the market mechanism. Quarterly Journal of Economics, v. 89, n. 3, p. 488-500, 1970.

AL-AMRI, K.; AL-BUSAIDI, M.; AKGUC, S. Conservatism and corporate cash holdings: a risk prospective. Investment Management and Financial Innovations, v. 12, n. 1, p. 101-113, 2015.

AL-NAJJAR, B. The financial determinants of corporate cash holdings: Evidence from some emerging markets. International Business Review, v. 22, n. 1, p. 77-88, 2013.

ALDRIGHI, D. M.; BISINHA, R. Restrição ao crédito em Empresas com Ações Negociadas na BOVESPA. Revista Brasileira de Economia, v. 6, n. 1, p. 25-47, 2010.

ALMEIDA, H.; CAMPELLO, M.; WEISBACK, M. S. The Cash Flow Sensitivity of Cash. The Journal of Finance, v. 59, n. 4, p. 1777-1804, 2004.

AMESS, K.; BANERJI, S.; LAMPOUSIS, A. Corporate cash holdings: Causes and consequences. International Review of Financial Analysis, v. 42, n. 6, p. 421-433, 2015.

ANTUNES, M. T. P.; GRECCO, M. C. P.; FORMIGONI, H.; MENDONÇA NETO, O. R. A adoção no Brasil das normas internacionais de contabilidade IFRS: o processo e seus impactos na qualidade da informação contábil. Revista de Economia e Relações Internacionais, v. 10, n. 20, p. 5-19, 2012.

ASCIOGLU, A.; HEGDE, S. P.; MCDERMOTT, J. B. Information Asymmetry and Investment-Cash Flow Sensitivity. Journal of Banking \& Finance, v. 32, n. 6, p. 10361048, 2008.

ASLAN, H.; EASLEY, D.; HVIDKJAER, S.; O'HARA, M. The characteristics of informed trading: implications for asset pricing. Journal of Empirical Finance, v. 18, n. 5, p. 782-801, 2011.

ARATA, N.; SHENG, H. H.; LORA, M. I. Internationalization and Corporate Cash Holdings: Evidence from Brazil and Mexico. Revista de Administração Contemporânea, v. 19, n. 1, p. 1-19, 2015.

BALL, R. International financial reporting standards (IFRS): pros and cons for investors. Accounting and Business Research, v. 36, n. 1, p. 5-27, 2006.

BARTH, M.E.; LANDSMAN, W. R.; LANG, M. H. International accounting standards and accounting quality. Journal of Accounting Research, v. 46, n. 3, p. 467-498, 2008. 
BATES, T. W.; KAHLE, K. M.; STULZ, R. M. Why do US Firms hold so much more cash than they used to? The Journal of Finance, v. 64, n. 5, p. 1985-2021, 2009.

BAUMOL, W. J. The Transactions Demand for Cash: An Inventory Theoretic Approach. Quarterly Journal of Economics, v. 66, n. 4, p. 545-556, 1952.

BEATTY, R. P. Auditor reputation and the pricing of initial public offerings. The Accounting Review, v. 64, n. 4, p. 693-709, 1989.

BECK, T.; DEMIRGÜÇ-KUNT, A.; LAEVEN, L.; MAKSIMOVIC, V. The determinants of financing obstacles. Journal of International Money and Finance, v. 25, n. 6, p. 932-952, 2006.

BRASIL. Lei 10.303, de 31 de outubro de 2001. Altera e acrescenta dispositivos na Lei no 6.404, de 15 de dezembro de 1976, que dispõe sobre as Sociedades por Ações, e na Lei no 6.385, de 7 de dezembro de 1976, que dispõe sobre o mercado de valores mobiliários e cria a Comissão de Valores Mobiliários. Disponível em: http://www.planalto.gov.br/ccivil_03/leis/L6404compilada.htm. Acesso em: 18 de junho de 2016.

BROWN, P. Some observations on research on the benefits to nations of adopting IFRS. The Japanese Accounting Review, v. 3, p. 1-19, 2013.

BYARD, D.; LI, Y.; YU, Y. The Effect of Mandatory IFRS Adoption on Financial Analysts' Information Environment. Journal of Accounting Research, v. 49, n. 1, p. 6996, 2011.

CAMPELLO, M. Contemporary corporate finance research on South America. Journal of Corporate Finance, v. 18, n. 4, p. 879-882, 2012.

CAMPELLO, M; GIAMBONA, E.; GRAHAM, J. R.; HARVEY, C. R. Liquidity Management and Corporate Investment During a Financial Crisis. Review of Financial Studies, v. 24, n. 6, p. 1944-1979, 2011.

CAMPELLO, M.; GRAHAM, J. R.; HARVEY, C. R. The real effects of financial constraints: Evidence from a financial crisis. Journal of Financial Economics, v. 97, n. 3, p. 470-487, 2010.

CARVALHO, A. G. de.; PENNACCHI, G. G. Can a stock exchange improve corporate behavior? Evidence from firms' migration to premium listings in Brazil. Journal of Corporate Finance, v. 18, n. 4, p. 883-903, 2012.

CHALHOUB, L.; KIRCH, G.; TERRA, P. R. S. Fontes de Caixa e Restrições Financeiras: Evidências das Firmas Listadas na BM\&FBOVESPA. Revista Brasileira de Finanças, v. 13, n. 3, p. 470-503, 2015.

CHANG, K.; NOORBAKHSH, A. Does national culture affect international corporate cash holdings? Journal of Multinational Financial Management, v. 19, n. 5, p. 323-342, 2009. 
CHEN, Q.; CHEN, X.; SCHIPPER, K.; XU, Y.; XUE, J. The Sensitivity of Corporate Cash Holdings to Corporate Governance. The Review of Financial Studies, v. 25, n. 12, p. 3610-3644, 2012.

CHRISTENSEN, H. B.; HAIL, L.; LEUZ, C. Mandatory IFRS Reporting and Changes in Enforcement. Journal of Accounting and Economics, v. 56, n. 2-3, p. 147-177, 2013.

CHUNG, K. H.; KIM, J.; KIM, Y. S.; ZHANG, H. Information Asymmetry and Corporate Cash Holdings. Journal of Business Finance \& Accounting, v. 42, n. 9-10, p. 1341-1377, 2015.

CLEARY, S.; POVEL, P.; RAITH, M. The U-Shaped Investment Curve: Theory and Evidence. Journal of Financial and Quantitative Analysis, v. 42, n. 1, p. 1- 40, 2007.

COSTA, C. M.; PAZ, L. S.; FUNCHAL, B. Fluxo de Caixa, ADRs e Restrições de Crédito no Brasil. Brazilian Business Review, v. 5, n. 2, p. 144-151, 2008a.

COSTA, C. M.; PAZ, L. S.; FUNCHAL, B. Are Brazilian Firms Savings Sensitive to Cash Windfalls? Brazilian Business Review, v. 5, n. 2, p. 136-142, $2008 \mathrm{~b}$.

CPC - Comitê de Pronunciamentos Contábeis (2010) - CPC 03 (R2): Demonstração dos Fluxos de Caixa. $\quad$ Disponível em:< http://static.cpc.mediagroup.com.br/Documentos/183_CPC_03_R2_rev\%2004.pdf> . Acesso em: 16/01/2016.

DAHROUGE, F. M.; SAITO, R. Políticas de Cash Holdings: Uma Abordagem Dinâmica das Empresas Brasileiras. Revista Brasileira de Finanças, v. 11, n. 3, p. 343-373, 2013.

DASKE, H. Economic benefits of adopting IFRS or US-GAAP: Have the expected cost of equity capital really decreased? Journal of Business Finance \& Accounting, v. 33, n. 3-4, p. 329-373, 2006.

DASKE, H.; HAIL, L.; LEUZ, C.; VERDI, R. Mandatory IFRS Reporting around the World: Early Evidence on the Economic Consequences. Journal of Accounting Research, v. 46, n. 5, p. 1085-1142, 2008.

DASKE, H.; HAIL, L.; LEUZ, C.; VERDI, R. Adopting a label: heterogeneity in the consequences of IFRS adoptions. Journal of Accounting Research, v. 51, n. 3, p. 495$547,2013$.

DENIS, D. J.; SIBILKOV, V. Financial constraints, investment, and the value of cash holdings. Review of Financial Studies, v. 23, n. 1, p. 247-269, 2010.

DENIS, D. K.; MCCONNEL, J. J. International Corporate Governance. The Journal of Financial and Quantitative Analysis, v. 38, n. 1, p. 1-36, 2003.

DITTMAR, A.; MAHRT-SMITH, J. Corporate governance and the value of cash holdings. Journal of Financial Economics, v. 83, n. 3, p. 599-634, 2007. 
DITTMAR, A.; MAHRT-SMITH, J.; SERVAES, H. International Corporate Governance and Corporate Cash Holdings. The Journal of Financial and Quantitative Analysis, v. 38, n. 1, p. 111-133, 2003.

DROBETZ, W.; GRÜNINGER, M. C.; HIRSCHVOGL, S. Information asymmetry and the value of cash. Journal of Banking \& Finance, v. 34, n. 9, p. 2168-2184, 2010.

EASLEY, D.; O'HARA, M. Information and the Cost of Capital. The Journal of Finance, v. 59, n. 4, p. 1553-1583, 2004.

FARRE-MENSA, J.; LJUNGQVIST, A. Do measures of financial constraints measure financial constraints? Review of Financial Studies, v. 2, n. 2, p. 271-308, 2016.

FAULKENDER, M. W.; WANG, R. Corporate Financial Policy and the Value of Cash. Journal of Finance, v. 61, n. 4, p. 1957-1990, 2006.

FÁVERO, L. P. L. Análise de Dados: Modelos de Regressão com Excel®, Stata® e SPSS®. Rio de Janeiro: Elsevier, 2015.

FÁVERO, L. P. L. Panel data in accounting and finance: theory and application. Brazilian Business Review, v. 10, n. 1, p. 131-156, 2013.

FÁVERO, L. P. L.; BELFIORE, P.; SILVA, F. L.; CHAN, B. L. Análise de Dados: Modelagem Multivariada para Tomada de Decisões. Rio de Janeiro: Elsevier, 2009.

FAZZARI, S. M.; HUBBARD, G. R.; PETERSEN, B. C. Financing Constraints and Corporate Investment. Brookings Papers on Economic Activity, v. 1, n.1, p. 141-195, 1988.

FAZZARI, S. M.; HUBBARD, G. R.; PETERSEN, B. C. Investment-Cash Flow Sensitivities are Useful: A comment on Kaplan and Zingales. Quarterly Journal of Economics, v. 115, n. 2, p. 695-705, 2000.

FERREIRA, M. A.; VILELA, A. S. Why do firms hold cash? Evidence from EMU countries. European Financial Management, v. 10, n. 2, p. 295-319, 2004.

FERREIRA, R. N.; SANTOS, A. C.; LOPES, A. L. M.; NAZARETH, L. G. C.; FONSECA, R. A. Governança corporativa, eficiência, produtividade e desempenho. RAM. Revista de Administração Mackenzie, v. 14, n. 4, p. 134-164, 2013.

FRANKEL, R.; LI, X. Characteristics of a firm's information environment and the information asymmetry between insiders and outsiders. Journal of Accounting and Economics, v. 37, n. 2, p. 229-259, 2004.

GAO, H.; HARFORD, J.; LI, K. Determinants of corporate cash policy: Insights from private firms. Journal of Financial Economics, v. 109, n. 3, p. 623-639, 2013.

GHANI, A. N. A.; MARTELANC, R.; KAYO, E. K. Is There a Difference in Credit Constraints Between Private and Listed Companies in Brazil? Empirical Evidence by the 
Cash Flow Sensitivity Approach. Revista Contabilidade \& Finanças, v. 26, n. 67, p. 8592, 2015.

GILCHRIST, S.; HIMMELBERG, C. P. Evidence on the Role of Cash Flow for Investment. Journal of Monetary Economics, v. 36, n. 3, p. 541-572, 1995.

GRAHAM, J. R.; LEARY, M. T. The Evolution of Corporate Cash. Working Paper, 2015.

GUNEY, Y.; OZKAN, A.; OZKAN, N. International evidence on the non-linear impact of leverage on corporate cash holdings. Journal of Multinational Financial Management, v. 17, n. 1, p. 45-60, 2007.

HAN, S.; QIU, J. Corporate Precautionary Cash Holdings. Journal of Corporate Finance, v. 13, n. 1, p. 43-57, 2007.

HARFORD, J. Corporate Cash Reserves and Acquisitions. The Journal of Finance, v. 54, n. 6, p. 1969-1997, 1999.

HARFORD, J.; MANSI, S. A.; MAXWELL, W. F. Corporate governance and firm cash holdings in the US. Journal of Financial Economics, v. 87, n. 3, p. 535-555, 2008.

IBGE (Instituto Brasileiro de Geografia e Estatística). Comissão Nacional de Classificação. Disponível em: < http://cnae.ibge.gov.br/?view=estrutura>. Acesso em: 20 de junho de 2016.

IFRS (International Financial Reporting Standards). IFRS as global standards: a pocket guide. Disponível em: <http://www.ifrs.org/Use-around-the-world/Documents/IFRS-asglobal-standards-Pocket-Guide-April-2015.PDF>. Acesso em: 20 de março de 2016.

JAIN, B. A.; LI, J.; SHAO, Y. Governance, product market competition and cash management in IPO firms. Journal of Banking \& Finance, v. 37, n. 6, p. 2052-2068, 2013.

JENSEN, M. C. Agency Costs of Free Cash Flow, Corporate Finance, and Takeovers. The American Economic Review, v. 76, n. 2, p. 323-329, 1986.

JENSEN, M. C.; MECKLING W. H. Theory of the firm: Managerial behavior, agency costs and ownership structure. Journal of Financial Economics, v. 3, n. 4, p. 305-360, 1976.

JIANG, Z.; LIE, E. Cash holding adjustments and managerial entrenchment. Journal of Corporate Finance, v. 36, n. 3, p. 190-205, 2016.

KADAPAKKAM, P.; KUMAR, P. C.; RIDDICK, L. A. The impact of cash flows and firm size on investment: The international evidence. Journal of Banking \& Finance, v. 22, n. 3, p. 293-320, 1998.

KAHLE, K. M.; STULZ, R. M. Access to capital, investment, and the financial crisis. Journal of Financial Economics, v. 110, n. 2, p. 280-299, 2013. 
KALCHEVA, I.; LINS, K. V. International Evidence on Cash Holdings and Expected Managerial Agency Problems. The Review of Financial Studies, v. 20, n. 4, p. 1087-1112, 2007.

KAPLAN, S. N.; ZINGALES, L. Do Investment-Cash Flow Sensitivities Provide Useful Measures of Financing Constraints? Quarterly Journal of Economics, v. 112, n. 1, p. 169$215,1997$.

KAPLAN, S. N.; ZINGALES, L. Investment-Cash Flow Sensitivities are not Valid Measures of Financing Constraints. Quarterly Journal of Economics, v. 115, n. 2, p. 707$712,2000$.

KEYNES, J. M. The General Theory of Employment, Interest and Money. London: McMillan, 1936.

KIM, C.; MAUER, D. C.; SHERMAN, A. E. The Determinants of Corporate Liquidity: Theory and Evidence. Journal of Financial and Quantitative Analysis, v. 33, n. 3, p. 335359, 1998.

KIRCH; G.; PROCIANOY, J. L.; TERRA, P. R. S. Restrições Financeiras e a Decisão de Investimento das Firmas Brasileiras. Revista Brasileira de Economia, v. 68, n. 1, p.103-123, 2014.

LA PORTA, R.; LOPEZ-DE-SILANES, F.; SHLEIFER, A.; VISHNY, R. W. Law and finance. The Journal of Political Economy, v. 106, n. 6, p. 1113-1155, 1998.

LAMEIRA, V. J.; NESS JÚNIOR, W. L.; MACEDO-SOARES, T. D. L. A. Governança corporativa: impactos no valor das companhias abertas brasileiras. Revista de Administração, v. 42, n. 1, p. 64-73, 2007.

LANG, L.; OFEK, E.; STULZ, R. M. Leverage, investment, and firm growth. Journal of Financial Economics, v. 40, n. 1, p. 3-29, 1996.

LEE, E.; WALKER, M.; CHRISTENSEN, H. B. Mandating IFRS: It's Impact on the Cost of Equity Capital in Europe. Journal of International Accounting Research, v. 9, n. 1, p. 58-59, 2010.

LÓPEZ-GUTIÉRREZ, C.; SANFILIPPO-AZOFRA, S.; TORRE-OLMO, B. Investment decisions of companies in financial distress. BRQ Business Research Quarterly, v. 18, n. 3, p. 174-187, 2015.

LOURENÇO, I. C.; BRANCO, M. C. A Governança Corporativa e o Efeito da Adoção das IFRS: O Caso Brasileiro. Revista Universo Contábil, v. 11, n. 1, p. 157-172, 2015a.

LOURENÇO, I. M. E. C.; BRANCO, M. E. M. de A. D. C. Main consequences of IFRS adoption: Analysis of existing literature and suggestions for further research. Revista Contabilidade \& Finanças, v. 26, n. 68, p. 126-139, 2015 b.

LUO, M. M. A bright side of financial constraints in cash management. Journal of Corporate Finance, v. 17, n. 5, p. 1430-1444, 2011. 
LYANDRES, E. Costly external financing, investment timing, and investment-cash flow sensitivity. Journal of Corporate Finance, v. 13, n. 5, p. 959-980, 2007.

MARTINS, O. S.; PAULO, E. Information asymmetry in stock trading, economic and financial characteristics and corporate governance in the Brazilian stock market. Revista Contabilidade \& Finanças, v. 25, n. 64, p. 33-45, 2014.

MILLER, M. H.; ORR, D. A model of the demand for money by firms. The Quarterly Journal of Economics, v. 80, n. 3, p. 413-435, 1966.

MINTON, A. B.; SCHRAND, C. The impact of cash flow volatility on discretionary investment and the cost of debt and equity financing. Journal of Financial Economics, v. 54, n. 3, p. 423-460, 1999.

MODIGLIANI, F.; MILLER, M. H. The cost of capital, corporation finance and the theory of investment. The American Economic Review, v. 48, n. 3, p. 261-297, 1958.

MOSCARIELLO, N.; SKERRATT, L.; PIZZO, M. Mandatory IFRS adoption and the cost of debt in Italy and UK. Accounting and Business Research, v. 44, n. 1, p. 63-82, 2014.

MOYEN, N. Investment-Cash Flow Sensitivities: Constrained versus Unconstrained Firms. The Journal of Finance, v. 59, n. 5, p. 2061-2092, 2004.

MYERS, S. C. The capital structure puzzle. The Journal of Finance. v. 39, n. 3, p. 575592,1984

MYERS, S. C.; MAJLUF, N. S. Corporate Financing and Investment Decisions When Firms Have Information that Investors do not Have. Journal of Financial Economics, v. 13, n. 2, p. 187-221, 1984.

NIKOLOV, B.; WHITED, T. Agency conflicts and cash: Estimates from a dynamic model. The Journal of Finance, v. 69, n. 5, p. 1883-1921, 2014.

OLER, D. K.; PICCONI, M. P. Implications of Insufficient and Excess Cash for Future Performance. Contemporary Accounting Research, v. 31, n. 1, p. 253-283, 2013.

OPLER, T.; PINKOWITZ, L.; STULZ, R.; WILLIAMSON, R. The determinants and implications of corporate cash holdings. Journal of Financial Economics, v. 52, n. 1, p. 3-46, 1999.

OZKAN, A.; OZKAN, N. Corporate cash holdings: An empirical investigation of UK companies. Journal of Banking \& Finance, v. 28, n. 9, p. 2103-2134, 2004.

ROSS, S. The economic theory of agency: the principal's problem. American Economic Review, n. 63, n. 2, p. 134-139, 1973. 
SANTOS, E. S.; CALIXTO, L. Impactos do início da harmonização contábil internacional (Lei 11.638/07) nos resultados das empresas abertas. RAE Eletrônica, v. 9, n. 1, p. 1-20, 2010.

SANTOS, E. S.; PONTE, V. M. R.; MAPURUNGA, P. V. R. Mandatory IFRS Adoption in Brazil (2010): Index of Compliance with Disclosure Requirements and some Explanatory Factors of Firms Reporting. Revista Contabilidade \& Finanças, v. 25, n. 65, p. 161-176, 2014.

SODERSTROM, N. S.; SUN, K. J. IFRS adoption and accounting quality: A review. European Accounting Review, v. 16, n. 4, p. 675-702, 2007.

SUN, Z.; WANG, Y. Corporate precautionary savings: Evidence from the recent financial crisis. The Quarterly Review of Economics and Finance, v. 56, n. 3, p. 175-186, 2015.

TONG, Z. Firm diversification and the value of corporate cash holdings. Journal of Corporate Finance, v. 17, n 3, p. 741-758, 2011.

TORTOLI, J. P.; MORAES, M. B. C. da. Fatores de Impacto sobre o Saldo de Caixa: Um Estudo em Empresas Brasileiras Não Financeiras de Capital Aberto. Revista Brasileira de Finanças, v. 14, n. 1, p. 125-150, 2016.

UYAR, A.; KUZEY, C. Determinants of corporate cash holdings: evidence from the emerging market of Turkey. Applied Economics, v. 46, n. 9, p. 1035-1048, 2014. 


\section{APÊNDICES}

Apêndice 1. Modelo de Regressão de Mínimos Quadrados Ordinários com Erros-Padrão Robusto

\begin{tabular}{|c|c|c|c|c|}
\hline Variáveis & Coeficientes & $\begin{array}{c}\text { Erro } \\
\text { Padrão }\end{array}$ & Razão- $t$ & p-valor \\
\hline Constante & $-7,1295$ & 1,4746 & $-4,835$ & $3,46 \mathrm{e}-06 * * *$ \\
\hline Dividendos & $-0,0007$ & 0,0094 & $-0,07414$ & 0,9410 \\
\hline Restrita (Tamanho) & 0,4562 & 0,3437 & 1,3270 & 0,1866 \\
\hline Irrestrita (Tamanho) & $-0,4757$ & 0,3953 & $-1,203$ & 0,2309 \\
\hline Restrita (Idade) & 0,1593 & 0,3243 & 0,4913 & 0,6240 \\
\hline Irrestrita (Idade) & 0,0624 & 0,2985 & 0,2092 & 0,8346 \\
\hline Dummy Nível 1 & 0,6421 & 0,2673 & 2,4020 & $0,0176 * *$ \\
\hline Dummy Nível 2 & 0,2959 & 0,2806 & 1,0540 & 0,2936 \\
\hline Dummy Novo Mercado & 0,7627 & 0,2554 & 2,986 & $0,0033 * * *$ \\
\hline Dummy ADR & 0,0221 & 0,4132 & 0,0534 & 0,9574 \\
\hline Dummy Big 4 & 0,4688 & 0,1706 & 2,723 & $0,0073 * * *$ \\
\hline Tamanho & 0,1184 & 0,0839 & 1,411 & 0,1604 \\
\hline Idade & 0,0547 & 0,1797 & 0,3087 & 0,7580 \\
\hline Alavancagem Financeira & 0,0047 & 0,0038 & 1,2420 & 0,2163 \\
\hline Endividamento & 1,3163 & 0,4251 & 3,0960 & $0,0024 * * *$ \\
\hline Geração de Caixa & 0,0009 & 0,0026 & 0,3565 & 0,7220 \\
\hline $\begin{array}{l}\text { Oportunidades de } \\
\text { Investimento }\end{array}$ & 2,5094 & 0,6422 & 3,9070 & $0,0001 * * *$ \\
\hline ROE & 0,0221 & 0,0421 & 0,5249 & 0,6005 \\
\hline $\mathrm{ROA}$ & 0,8305 & 0,2766 & 3,002 & $0,0032 * * *$ \\
\hline $\mathrm{LC}$ & $-0,0214$ & 0,0069 & $-3,0860$ & $0,0024 * * *$ \\
\hline $\mathrm{CCL}$ & 0,0000 & 0,0000 & 1,7050 & $0,0905 *$ \\
\hline Dívidas de Curto Prazo & 2,4016 & 0,6630 & 3,6220 & $0,0004 * * *$ \\
\hline Dummy Crise & 0,2371 & 0,1154 & 2,0550 & $0,0417 * *$ \\
\hline Dummy IFRS & $-0,3913$ & 0,1347 & $-2,9040$ & $0,0043 * * *$ \\
\hline Dummy Indústria & $-0,4241$ & 0,2870 & $-1,4780$ & 0,1417 \\
\hline Dummy Serviços & 0,4197 & 0,3198 & 1,3120 & 0,1916 \\
\hline$R^{2}=0,345065$ & & $\begin{array}{c}\mathrm{LM}= \\
718,519\end{array}$ & $\begin{array}{c}\text { P(Qui-quadrado(37) > } \\
718,7)=3,47616 e-127 \\
\end{array}$ & \\
\hline Observações $(n)$ & 1906 & & & \\
\hline Teste de Durbin-Watson & 0,587729 & & & \\
\hline
\end{tabular}

Fonte: Elaboração própria.

Notas: * estatisticamente significativo a 10\%; ** estatisticamente significativo a 5\%; *** estatisticamente significativo a $1 \%$.

Apêndice 2. Modelo de Regressão de Efeitos Aleatórios com Erros-Padrão Robusto

\begin{tabular}{l|c|c|c|c}
\hline \multicolumn{1}{c|}{ Variáveis } & Coeficientes & Erro Padrão & Z & p-valor \\
\hline Constante & $-7,5792$ & 54128,7 & $-0,0001$ & 0,9999 \\
\hline Dividendos & $-0,0094$ & 79,2650 & $-0,0001$ & 0,9999 \\
\hline Restrita (Tamanho) & 0,4503 & 403,1320 & 0,0011 & 0,9991 \\
\hline Irrestrita (Tamanho) & $-0,4466$ & 2556,83 & $-0,0001$ & 0,9999 \\
\hline Restrita (Idade) & $-0,0890$ & 2318,19 & 0,0000 & 1,0000 \\
\hline Irrestrita (Idade) & $-0,4539$ & 4254,84 & $-0,0001$ & 0,9999 \\
\hline
\end{tabular}




\begin{tabular}{|c|c|c|c|c|}
\hline Dummy Nível 1 & 0,1918 & 586,840 & 0,0003 & 0,9997 \\
\hline Dummy Nível 2 & 0,7073 & 3232,74 & 0,0002 & 0,9998 \\
\hline Dummy Novo Mercado & 0,3377 & 1554,65 & 0,0002 & 0,9998 \\
\hline Dummy ADR & 0,4193 & 259,81 & 0,0016 & 0,9987 \\
\hline Dummy Big 4 & 0,1978 & 1181,79 & 0,0001 & 0,9999 \\
\hline Tamanho & 0,1637 & 4193,82 & 0,0000 & 1,0000 \\
\hline Idade & 0,1892 & 5933,06 & 0,0000 & 1,0000 \\
\hline Alavancagem Financeira & 0,0035 & 81,5185 & 0,0000 & 1,0000 \\
\hline Endividamento & 1,1713 & 3396,20 & 0,0003 & 0,9997 \\
\hline Geração de Caixa & 0,0000 & 27,3699 & 0,0000 & 1,0000 \\
\hline Oportunidades de Investimento & 1,7817 & 42655,7 & 0,0000 & 1,0000 \\
\hline ROE & 0,0303 & 552,400 & 0,0000 & 1,0000 \\
\hline ROA & 0,4906 & 7262,67 & 0,0000 & 0,9999 \\
\hline $\mathrm{LC}$ & $-0,0136$ & 443,74 & 0,0000 & 1,0000 \\
\hline $\mathrm{CCL}$ & 0,0000 & 0,0002 & 0,0002 & 0,9998 \\
\hline Dívidas de Curto Prazo & 1,7674 & 51912,4 & 0,0000 & 1,0000 \\
\hline Dummy Crise & 0,2941 & 3571,20 & 0,0001 & 0,9999 \\
\hline Dummy IFRS & $-0,3676$ & 738,20 & $-0,0004$ & 0,9996 \\
\hline Dummy Indústria & $-0,4019$ & 1169,89 & $-0,0003$ & 0,9997 \\
\hline Dummy Serviços & 0,4257 & 650,657 & 0,0006 & 0,9995 \\
\hline $\operatorname{corr}(y, y h a t)^{\wedge} 2=0,311509$ & & $\begin{array}{c}\text { Qui-quadrado }(25)= \\
910,244\end{array}$ & $\begin{array}{c}\text { P-valor = } \\
0,000297384\end{array}$ & \\
\hline Observações (n) & 1906 & & & \\
\hline
\end{tabular}

Fonte: Elaboração própria. 
Apêndice 3. Matriz de Correlação

\begin{tabular}{|c|c|c|c|c|c|c|c|c|c|c|c|c|c|}
\hline Variáveis & $\begin{array}{c}\text { Cash } \\
\text { Holding }\end{array}$ & Dividendos & $\begin{array}{c}\text { Restrita } \\
\text { (Tamanho) }\end{array}$ & $\begin{array}{l}\text { Irrestrita } \\
\text { (Tamanho) }\end{array}$ & $\begin{array}{l}\text { Restrita } \\
\text { (Idade) }\end{array}$ & $\begin{array}{c}\text { Irrestrita } \\
\text { (Idade) }\end{array}$ & N1 & N2 & NM & ADR & Big 4 & LnAtivo & LnIdade \\
\hline Cash Holding & 1 & & & & & & & & & & & & \\
\hline Dividendos & 0,041 & 1 & & & & & & & & & & & \\
\hline Restrita (Tamanho) & $-0,070$ & $-0,037$ & 1 & & & & & & & & & & \\
\hline Irrestrita (Tamanho) & 0,063 & 0,056 & $-0,334$ & 1 & & & & & & & & & \\
\hline Restrita (Idade) & $-0,014$ & 0,003 & 0,014 & 0,0226 & 1 & & & & & & & & \\
\hline Irrestrita (Idade) & 0,002 & $-0,022$ & $-0,155$ & 0,0900 & $-0,3408$ & 1 & & & & & & & \\
\hline N1 & 0,135 & 0,048 & $-0,216$ & 0,2858 & $-0,1261$ & 0,104 & 1 & & & & & & \\
\hline $\mathrm{N} 2$ & 0,055 & 0,010 & $-0,085$ & 0,0337 & $-0,0685$ & 0,091 & $-0,055$ & 1 & & & & & \\
\hline Novo Mercado & 0,125 & 0,019 & $-0,169$ & 0,2386 & $-0,0056$ & 0,051 & $-0,110$ & $-0,043$ & 1 & & & & \\
\hline Dummy ADR & 0,088 & 0,050 & $-0,203$ & 0,5665 & 0,0300 & $-0,110$ & 0,297 & $-0,052$ & 0,232 & 1 & & & \\
\hline Dummy Big 4 & 0,199 & 0,027 & $-0,483$ & 0,3115 & 0,0470 & 0,067 & 0,250 & 0,123 & 0,199 & 0,231 & 1 & & \\
\hline LnAtivo & 0,108 & 0,087 & $-0,719$ & 0,7439 & $-0,0418$ & 0,055 & 0,336 & 0,069 & 0,220 & 0,555 & 0,499 & 1 & \\
\hline LnIdade & 0,032 & 0,009 & $-0,060$ & $-0,0009$ & $-0,8340$ & 0,581 & 0,138 & 0,093 & 0,067 & $-0,049$ & $-0,030$ & 0,044 & 1 \\
\hline $\mathrm{AF}$ & 0,032 & $-0,011$ & $-0,068$ & 0,0133 & $-0,0441$ & $-0,046$ & 0,027 & 0,059 & 0,011 & 0,010 & 0,067 & 0,061 & 0,032 \\
\hline End & 0,173 & 0,027 & $-0,374$ & 0,3250 & 0,0074 & 0,123 & 0,220 & 0,037 & 0,171 & 0,206 & 0,350 & 0,465 & 0,050 \\
\hline GC & 0,061 & 0,031 & $-0,074$ & 0,040 & 0,041 & 0,018 & 0,072 & $-0,036$ & $-0,053$ & $-0,018$ & 0,163 & 0,039 & $-0,027$ \\
\hline OI & 0,324 & 0,036 & $-0,009$ & $-0,0326$ & $-0,0602$ & $-0,010$ & 0,022 & 0,019 & 0,026 & $-0,020$ & 0,020 & $-0,024$ & 0,058 \\
\hline ROE & 0,021 & 0,001 & 0,042 & 0,0073 & $-0,0465$ & $-0,011$ & 0,004 & $-0,013$ & 0,015 & $-0,001$ & $-0,029$ & 0,007 & 0,043 \\
\hline $\mathrm{ROA}$ & 0,222 & 0,024 & $-0,163$ & 0,0841 & $-0,0731$ & 0,024 & 0,064 & 0,026 & 0,070 & 0,043 & 0,113 & 0,183 & 0,085 \\
\hline $\mathrm{LC}$ & 0,103 & 0,005 & 0,061 & $-0,0261$ & 0,0486 & $-0,017$ & $-0,011$ & $-0,005$ & $-0,010$ & $-0,016$ & $-0,033$ & $-0,106$ & $-0,038$ \\
\hline $\mathrm{CCL}$ & 0,128 & 0,144 & $-0,127$ & 0,3305 & $-0,0858$ & $-0,011$ & 0,227 & $-0,009$ & 0,019 & 0,389 & 0,167 & 0,418 & 0,077 \\
\hline $\mathrm{DCP}$ & $-0,088$ & $-0,026$ & 0,136 & $-0,0961$ & 0,0421 & $-0,012$ & $-0,052$ & 0,011 & $-0,034$ & $-0,067$ & $-0,088$ & $-0,175$ & $-0,029$ \\
\hline Crise & 0,096 & 0,060 & 0,014 & 0,0139 & $-0,0172$ & 0,013 & 0,019 & 0,006 & 0,042 & 0,011 & $-0,032$ & 0,007 & 0,025 \\
\hline IFRS & $-0,045$ & 0,078 & $-0,070$ & 0,0793 & $-0,0465$ & 0,074 & 0,063 & 0,068 & 0,148 & 0,033 & 0,122 & 0,100 & 0,128 \\
\hline Indústria & $-0,058$ & $-0,007$ & 0,085 & $-0,2001$ & $-0,2110$ & 0,108 & 0,139 & $-0,052$ & 0,024 & $-0,110$ & $-0,130$ & $-0,165$ & 0,256 \\
\hline Serviço & 0,058 & 0,012 & 0,048 & 0,0631 & 0,3165 & $-0,137$ & $-0,125$ & $-0,053$ & $-0,003$ & 0,019 & 0,019 & $-0,024$ & $-0,318$ \\
\hline Comércio & 0,022 & $-0,002$ & $-0,129$ & 0,1747 & 0,0022 & $-0,019$ & $-0,062$ & 0,096 & $-0,024$ & 0,107 & 0,129 & 0,200 & $-0,050$ \\
\hline
\end{tabular}

Fonte: Elaboração própria. 
Apêndice 3. Continuação Matriz de Correlação

\begin{tabular}{|c|c|c|c|c|c|c|c|c|c|c|c|c|c|c|}
\hline Variáveis & $\mathrm{AF}$ & End & GC & OI & ROE & ROA & LC & $\mathrm{CCL}$ & DCP & Crise & IFRS & Indústria & Serviço & Comércio \\
\hline $\mathrm{AF}$ & 1 & & & & & & & & & & & & & \\
\hline End & 0,052 & 1 & & & & & & & & & & & & \\
\hline GC & $-0,007$ & 0,016 & 1 & & & & & & & & & & & \\
\hline OI & 0,004 & $-0,062$ & 0,029 & 1 & & & & & & & & & & \\
\hline ROE & $-0,091$ & $-0,024$ & 0,026 & 0,009 & 1 & & & & & & & & & \\
\hline ROA & 0,031 & 0,021 & 0,006 & 0,385 & 0,004 & 1 & & & & & & & & \\
\hline LC & $-0,009$ & $-0,065$ & 0,011 & 0,430 & 0,002 & 0,031 & 1 & & & & & & & \\
\hline $\mathrm{CCL}$ & 0,013 & 0,127 & 0,005 & 0,037 & 0,016 & 0,061 & $-0,003$ & 1 & & & & & & \\
\hline $\mathrm{DCP}$ & $-0,031$ & $-0,044$ & 0,001 & $-0,774$ & 0,009 & $-0,357$ & $-0,028$ & $-0,063$ & 1 & & & & & \\
\hline Crise & 0,003 & 0,016 & $-0,013$ & 0,017 & 0,032 & $-0,006$ & $-0,008$ & 0,031 & 0,003 & 1 & & & & \\
\hline IFRS & 0,014 & 0,036 & $-0,005$ & 0,008 & $-0,019$ & 0,024 & 0,040 & 0,100 & 0,007 & $-0,280$ & 1 & & & \\
\hline Indústria & $-0,016$ & $-0,003$ & $-0,090$ & 0,004 & $-0,002$ & $-0,034$ & $-0,036$ & 0,117 & 0,061 & $-0,003$ & $-0,031$ & 1 & & \\
\hline Serviço & 0,002 & 0,020 & $-0,057$ & $-0,039$ & $-0,040$ & $-0,120$ & $-0,006$ & $-0,059$ & 0,011 & $-0,005$ & $-0,001$ & $-0,465$ & 1 & \\
\hline Comércio & 0,016 & $-0,011$ & 0,141 & 0,024 & 0,031 & 0,125 & 0,045 & $-0,086$ & $-0,075$ & 0,007 & 0,035 & $-0,764$ & $-0,215$ & 1 \\
\hline
\end{tabular}

Fonte: Elaboração própria.

Nota: Onde N1 (Nível 1), N2 (Nível 2), NM (Novo Mercado), AF (Alavancagem Financeira), End (Endividamento), GC (Geração de Caixa), OI (Oportunidades de Investimento), ROE (Retorno sobre o Patrimônio Líquido), ROA (Retorno sobre o Ativo), LC (Liquidez Corrente), CCL (Capital Circulante Líquido) e DCP (Dívidas de Curto Prazo). 
Apêndice 4. Teste da Normalidade de Shapiro- Wilk

\begin{tabular}{l|c|c}
\hline \multicolumn{1}{c|}{ Variáveis } & $\begin{array}{c}\text { Teste da normalidade } \\
\text { de Shapiro-Wilk }\end{array}$ & p-valor \\
\hline Cash Holding & 0,9240 & 0,0000 \\
\hline Dividendos & 0,1126 & 0,0000 \\
\hline Restrita (Tamanho) & 0,5388 & 0,0000 \\
\hline Irrestrita (Tamanho) & 0,5388 & 0,0000 \\
\hline Restrita (Idade) & 0,5414 & 0,0000 \\
\hline Irrestrita (Idade) & 0,5427 & 0,0000 \\
\hline Dummy Nível 1 & 0,3836 & 0,0000 \\
\hline Dummy Nível 2 & 0,1238 & 0,0000 \\
\hline Dummy Novo Mercado & 0,2985 & 0,0000 \\
\hline Dummy ADR & 0,3614 & 0,0000 \\
\hline Dummy Big 4 & 0,6259 & 0,0000 \\
\hline Tamanho & 0,9966 & 0,0003 \\
\hline Idade & 0,8978 & 0,0000 \\
\hline Alavancagem Financeira & 0,5160 & 0,0000 \\
\hline Endividamento & 0,9540 & 0,0000 \\
\hline Geração de Caixa & 0,8462 & 0,0000 \\
\hline Oportunidades de Investimento & 0,3214 & 0,0000 \\
\hline ROE & 0,3965 & 0,0000 \\
\hline ROA & 0,4810 & 0,0000 \\
\hline LC & 0,0254 & 0,0000 \\
\hline CCL & 0,3002 & 0,0000 \\
\hline Dívidas de Curto Prazo & 0,1871 & 0,0000 \\
\hline Dummy Crise & 0,4058 & 0,0000 \\
\hline Dummy IFRS & 0,5940 & 0,0000 \\
\hline Dummy Indústria & 0,6143 & 0,0000 \\
\hline Dummy Serviços & 0,3718 & 0,0000 \\
\hline Dummy Comércio & 0,5478 & 0,0000 \\
\hline pópia & & \\
\hline
\end{tabular}

Fonte: Elaboração própria. 
Apêndice 5. Matriz de Correlação Fatores de Restrição

\begin{tabular}{|c|c|c|c|c|c|}
\hline Variáveis & Dividendos & $\begin{array}{c}\text { Restrita } \\
\text { (Tamanho) }\end{array}$ & $\begin{array}{c}\text { Irrestrita } \\
\text { (Tamanho) }\end{array}$ & $\begin{array}{r}\text { Restrita } \\
\text { (Idade) }\end{array}$ & $\begin{array}{c}\text { Irrestrita } \\
\text { (Idade) }\end{array}$ \\
\hline Dividendos & 1,0000 & $-0,3700$ & 0,0560 & 0,0030 & $-0,0220$ \\
\hline Restrita (Tamanho) & $-0,3700$ & 1,0000 & $-0,3340$ & 0,0140 & $-0,1550$ \\
\hline Irrestrita (Tamanho) & 0,0560 & $-0,3340$ & 1,0000 & 0,0230 & 0,0900 \\
\hline Restrita (Idade) & 0,0030 & 0,0140 & 0,0230 & 1,0000 & $-0,3410$ \\
\hline Irrestrita (Idade) & $-0,0220$ & $-0,1550$ & 0,0900 & $-0,3410$ & 1,0000 \\
\hline Dividendos & 1,0000 & 0,0520 & 0,0070 & 0,4400 & 0,1680 \\
\hline Restrita (Tamanho) & 0,0520 & 1,0000 & 0,0000 & 0,2670 & 0,0000 \\
\hline Irrestrita (Tamanho) & 0,0070 & 0,0000 & 1,0000 & 0,1620 & 0,0000 \\
\hline Restrita (Idade) & 0,4400 & 0,2670 & 0,1620 & 1,0000 & 0,0000 \\
\hline Irrestrita (Idade) & 0,1680 & 0,0000 & 0,0000 & 0,0000 & 1,0000 \\
\hline
\end{tabular}

Fonte: Elaboração própria.

Apêndice 6. Matriz de Correlação Fatores de Governança

\begin{tabular}{|c|c|c|c|c|c|}
\hline Variáveis & $\begin{array}{c}\text { Dummy Nível } \\
1 \\
\end{array}$ & \begin{tabular}{|l} 
Dummy Nível \\
2 \\
\end{tabular} & $\begin{array}{c}\text { Dummy Novo } \\
\text { Mercado }\end{array}$ & Dummy ADR & $\begin{array}{c}\text { Dummy } \\
\text { Big } 4\end{array}$ \\
\hline Dummy Nível 1 & 1,0000 & $-0,0550$ & $-0,1100$ & 0,2970 & 0,2500 \\
\hline Dummy Nível 2 & $-0,0550$ & 1,0000 & $-0,0430$ & $-0,0520$ & 0,1230 \\
\hline $\begin{array}{l}\text { Dummy Novo } \\
\text { Mercado }\end{array}$ & $-0,1100$ & $-0,0430$ & 1,0000 & 0,2320 & 0,1990 \\
\hline Dummy ADR & 0,2970 & $-0,0520$ & 0,2320 & 1,0000 & 0,2310 \\
\hline Dummy Big 4 & 0,2500 & 0,1230 & 0,1990 & 0,2310 & 1,0000 \\
\hline Dummy Nível 1 & 1,0000 & 0,0080 & 0,0000 & 0,0000 & 0,0000 \\
\hline Dummy Nível 2 & 0,0080 & 1,0000 & 0,0300 & 0,0120 & 0,0000 \\
\hline $\begin{array}{l}\text { Dummy Novo } \\
\text { Mercado }\end{array}$ & 0,0000 & 0,0300 & 1,0000 & 0,0000 & 0,0000 \\
\hline Dummy ADR & 0,0000 & 0,0120 & 0,0000 & 1,0000 & 0,0000 \\
\hline Dummy Big 4 & 0,0000 & 0,0000 & 0,0000 & 0,0000 & 1,0000 \\
\hline
\end{tabular}

Fonte: Elaboração própria.

Apêndice 7. Matriz Anti-Imagem Fatores de Restrição

\begin{tabular}{|c|c|c|c|c|c|}
\hline Variáveis & Dividendos & $\begin{array}{c}\text { Restrita } \\
\text { (Tamanho) }\end{array}$ & $\begin{array}{c}\text { Irrestrita } \\
\text { (Tamanho) }\end{array}$ & $\begin{array}{l}\text { Restrita } \\
\text { (Idade) }\end{array}$ & $\begin{array}{c}\text { Irrestrita } \\
\text { (Idade) }\end{array}$ \\
\hline Dividendos & 0,9950 & 0,0220 & $-0,0450$ & 0,0080 & 0,0290 \\
\hline Restrita (Tamanho) & 0,0220 & 0,8720 & 0,2830 & 0,021 & 0,1150 \\
\hline Irrestrita (Tamanho) & $-0,0450$ & 0,2830 & 0,8830 & $-0,0410$ & $-0,0490$ \\
\hline Restrita (Idade) & 0,0080 & 0,0210 & $-0,0410$ & 0,8800 & 0,2990 \\
\hline Irrestrita (Idade) & 0,0290 & 0,1150 & $-0,0490$ & 0,2990 & 0,8580 \\
\hline Dividendos & 0,5640 & 0,0230 & $-0,0480$ & 0,0080 & 0,0310 \\
\hline Restrita (Tamanho) & 0,0230 & 0,5280 & 0,3220 & 0,0240 & 0,1330 \\
\hline Irrestrita (Tamanho) & $-0,0480$ & 0,3220 & 0,5260 & $-0,0460$ & $-0,0560$ \\
\hline Restrita (Idade) & 0,0080 & 0,0240 & $-0,4600$ & 0,4900 & 0,3440 \\
\hline Irrestrita (Idade) & 0,0310 & 0,1330 & $-0,0560$ & 0,3440 & 0,5140 \\
\hline
\end{tabular}

Fonte: Elaboração própria. 
Apêndice 8. Matriz Anti-Imagem Fatores de Governança

\begin{tabular}{|c|c|c|c|c|c|}
\hline Variáveis & Dummy Nível 1 & $\begin{array}{l}\text { Dummy } \\
\text { Nível } 2\end{array}$ & $\begin{array}{c}\text { Dummy Novo } \\
\text { Mercado }\end{array}$ & $\begin{array}{c}\text { Dummy } \\
\text { ADR }\end{array}$ & $\begin{array}{c}\text { Dummy } \\
\text { Big } 4\end{array}$ \\
\hline Dummy Nível 1 & 0,8250 & 0,0760 & 0,1980 & $-0,2410$ & $-0,2020$ \\
\hline Dummy Nível 2 & 0,0760 & 0,9680 & 0,0670 & 0,0380 & $-0,1470$ \\
\hline $\begin{array}{l}\text { Dummy Novo } \\
\text { Mercado }\end{array}$ & 0,1980 & 0,0670 & 0,8710 & $-0,2080$ & $-0,1790$ \\
\hline Dummy ADR & $-0,2410$ & 0,0380 & $-0,2080$ & 0,8290 & $-0,0980$ \\
\hline Dummy Big 4 & $-0,2020$ & $-0,1470$ & $-0,1790$ & $-0,0980$ & 0,8520 \\
\hline Dummy Nível 1 & 0,4460 & 0,0850 & 0,2340 & $-0,2920$ & $-0,2420$ \\
\hline Dummy Nível 2 & 0,0850 & 0,3590 & 0,0730 & 0,0430 & $-0,1620$ \\
\hline $\begin{array}{l}\text { Dummy Novo } \\
\text { Mercado }\end{array}$ & 0,2340 & 0,0730 & 0,3970 & $-0,2450$ & $-0,2080$ \\
\hline Dummy ADR & $-0,2920$ & 0,0430 & $-0,2450$ & 0,5520 & $-0,1170$ \\
\hline Dummy Big 4 & $-0,2420$ & $-0,1620$ & $-0,2080$ & $-0,1170$ & 0,5480 \\
\hline
\end{tabular}

Fonte: Elaboração própria.

Apêndice 9. Teste de Kaiser-Meyer-Olkin e de Esfericidade de Bartlett para os Fatores de Restrição

\begin{tabular}{c|c|c}
\hline Medida Kaiser-Meyer-Olkin & & 0,515 \\
\hline Teste de esfericidade de Bartlett & Qui-quadrado & 524,883 \\
\hline & Graus de Liberdade & 10 \\
\hline & Significância & 0,000 \\
\hline
\end{tabular}

Fonte: Elaboração própria.

\section{Apêndice 9. Teste de Kaiser-Meyer-Olkin e de Esfericidade de Bartlett para os Fatores de} Governança

\begin{tabular}{c|c|c}
\hline Medida Kaiser-Meyer-Olkin & & 0,483 \\
\hline Teste de esfericidade de Bartlett & Qui-quadrado & 669,926 \\
\hline & Graus de Liberdade & 10 \\
\hline & Significância & 0,000 \\
\hline
\end{tabular}

Fonte: Elaboração própria. 